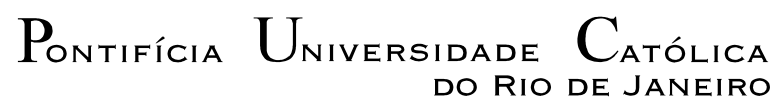
DO RIO DE JANEIRO

\author{
Jéssica Zacarias de Andrade
}

\title{
Aprendizagem Híbrida e Adaptativa: Caminhos na Relação Educação e Tecnologias
}

\section{Tese de Doutorado}

Tese apresentada como requisito parcial para obtenção do grau de Doutora pelo Programa de PósGraduação em Educação do Departamento de Educação da PUC-Rio.

Orientadora: Prof ${ }^{\mathrm{a}}$. Gilda Helena Bernardino de Campos

Rio de Janeiro

Agosto de 2018 


$$
\text { Pontifícia Universidade Católica }
$$

\author{
Jéssica Zacarias de Andrade
}

\title{
Aprendizagem Híbrida e Adaptativa: Caminhos na Relação Educação e Tecnologias
}

Tese apresentada como requisito parcial para obtenção do grau de Doutora pelo Programa de PósGraduação em Educação do Departamento de Educação da PUC-Rio. Aprovada pela Comissão Examinadora abaixo assinada.

$$
\begin{array}{r}
\text { Profa. Gilda Helena Bernardino de Campos } \\
\text { Orientadora } \\
\text { Departamento de Educação - PUC Rio }
\end{array}
$$

Prof.- Guilhermina Maria Lobato Ferreira de Miranda Instituto de Educação - Universidade de Lisboa

\section{Prof. Fábio Ferrentini Sampaio} NCE - UFRJ

Prof. Bernardo Pereira Nunes Departamento de Informática - PUC Rio

Prof. A Alicia Maria Catalano de Bonamino Departamento de Educação - PUC Rio

Prof ${ }^{a}$ Monah Winograd Coordenadora Setorial do Centro de Teologia e Ciências Humanas

Rio de Janeiro, 13 de agosto de 2018. 
Todos os direitos reservados. É proibida a reprodução total ou parcial do trabalho sem a autorização da universidade, da autora e da orientadora.

\section{Jéssica Zacarias de Andrade}

Graduou-se em Ciências Sociais na UERJ. Cursou pós-gradução lato sensu em Gestão de Recursos Humanos na UCAM. É mestre em Educação pela PUC Rio. Professora da rede pública estadual do Rio de Janeiro, tendo atuado como orientadora de gestão pedagógica. É integrante do grupo de pesquisa Cooperação e Avaliação em Educação a Distância.

Ficha Catalográfica

\section{Andrade, Jéssica Zacarias de}

Aprendizagem híbrida e adaptativa: caminhos na relação educação e tecnologias / Jéssica Zacarias de Andrade; orientadora: Gilda Helena B. de Campos. - 2018.

135 f. : il. color. ; $30 \mathrm{~cm}$

Tese (doutorado)-Pontifícia Universidade Católica do Rio de Janeiro, Departamento de Educação, 2018.

Inclui bibliografia

1. Educação - Teses. 2. Aprendizagem híbrida. 3. Aprendizagem adaptativa. 4. Curadoria, Design e Orientação. 5. TIC e educação. 6. Formação inicial de professores. I. Campos, Gilda Helena B. de. II. Pontifícia Universidade Católica do Rio de Janeiro. Departamento de Educação. III. Título. 
Ao meu marido Leandro e minha filha Sofia, por existirem em minha vida, por serem meu porto seguro e maior experiência de amor. 


\section{Agradecimentos}

À minha orientadora Gilda Helena Bernardino de Campos, pelo encorajamento, suporte, aprendizagens e parceria na realização deste trabalho.

À Guilhermina Miranda, pela receptividade, disponibilidade e aprendizagens intensas durante o período de estágio sanduíche no Instituto de Educação da Universidade de Lisboa.

À CAPES e à PUC Rio, pelo auxílios concedidos, sem os quais este trabalho não poderia ter sido realizado.

À Secretaria de Educação do Estado do Rio de Janeiro, pela licença concedida que me permitiu melhor dedicar à pesquisa.

Aos meus pais Eliete e Luiz pela educação, incentivo e carinho. Meu respeito e meu amor incondicional por vocês!

À minha irmã Ludimila, pela amizade e carinho.

Ao meu marido Leandro, pelo companherismo, dedicação e paciência. Sem você ao meu lado a conclusão deste trabalho não seria possível. Eu te amo!

À minha filha Sofia, pela parceria, aprendizagem contínua e por ser minha inspiração. Este trabalho existe porque você existe, menina sabida, mamãe te ama infinitamente!

Ao grupo de pesquisa Cooperação e Avaliação em Educação a Distância, por todas as aprendizagens compartilhadas.

À minha amiga Ana Paula, por estar sempre aberta ao debate construtivo e por me mostrar que podemos olhar por diferentes lentes, mas temos o mesmo objetivo.

Ao meu amigo Erisson, pelas constantes e ricas trocas, pela escuta atenta e pela disponibilidade em contribuir com este trabalho.

Aos professores da banca examinadora, pela disponibilidade e colaboração.

Aos professores respondentes do questionário, pela preciosa colaboração.

A todos os professores e funcionários do Departamento de Educação e da PUC Rio, pelos ensinamentos e apoio.

A todos os amigos e familiares que de alguma forma me ajudaram e estimularam nesta jornada.

A todos aqueles que ao longo do caminho se constituíram na rede apoio necessária a quem ousou ser mãe e pesquisadora. 


\section{Resumo}

Andrade, Jéssica Zacarias de. Campos. Gilda Helena Bernardino de. Aprendizagem Híbrida e Adaptativa: Caminhos na Relação Educação e Tecnologias. Rio de Janeiro, 135p. Tese de Doutorado - Departamento de Educação, Pontifícia Universidade Católica do Rio de Janeiro.

No contexto de uma sociedade digital emergem abordagens educativas mediadas pelas tecnologias digitais que visam respeitar o tempo, o ritmo e a forma de aprendizagem de cada aluno individualmente. As principais ideias embutidas na lógica das aprendizagens híbrida e adaptativa - autonomia, protagonismo do aluno, personalização do ensino, acompanhamento e avaliação contínua da aprendizagem - não são novas e também estão presentes na educação tradicional exclusivamente presencial. A principal diferença reside no fato de reconhecer na tecnologia o potencial de expansão das formas e lugares de aprendizagem dos alunos, oportunizando uma via paralela e integradora, não substitutiva e nem tampouco de caráter simplesmente complementar ao ensino presencial, para alcance dos objetivos de aprendizagem. O objetivo geral desta investigação é apresentar a concepção, operacionalização e implicações de duas abordagens educativas mediadas pelas tecnologias digitais, a aprendizagem híbrida e a aprendizagem adaptativa. A tese foi estruturada no formato multipaper contendo três estudos independentes que resguardam unidade temática e alinhamento teórico, mantendo assim uma inter-relação. A adoção de um modelo alternativo para a escrita da tese de doutorado responde a demanda do objeto de investigação, que é plural, de caráter difuso e multifacetado. O primeiro estudo, uma revisão sistemática da literatura a partir da produção acadêmica na área de Informática na Educação, buscou identificar as concepções e características de modelos híbridos e adaptativos que objetivam a personalização da aprendizagem. O segundo estudo é o relato de uma experiência de formação online destinada a professores que procurou explorar os conceitos de aprendizagem híbrida e adaptativa, assim como mobilizar mecanismos para sua operacionalização. O terceiro estudo pretendeu verificar, a partir da percepção de professores das licenciaturas e da análise dos currículos de seus 
cursos, se a formação inicial de professores está alinhada às abordagens educativas emergentes supracitadas, assim como seu entrelaçamento com as políticas públicas educacionais, específicas e complementares, que visam a promoção da incorporação das tecnologias digitais à educação. Compõe também este trabalho uma introdução, onde é apresentado o enquadramento teórico-conceitual transversal aos três estudos, assim como uma síntese conclusiva, onde se apresenta uma discussão integrada dos resultados. Os resultados da pesquisa mostram a necessidade de maior interlocução entre os profissionais das áreas de Informática e Educação no desenvolvimento de ambientes e sistemas que suportem a aprendizagem híbrida e adaptativa, o que implica na realização de mais pesquisas de caráter experimental e, principalmente, na reconfiguração da formação docente, inicial e continuada, no sentido de preparar efetivamente os professores para exercerem seu papel, que já não é mais de transmissores do conhecimento, mas de mediadores no processo de aprendizagem, ressignificando seu modus operandi $\mathrm{com}$ base em uma tríade de princípios norteadores: design, curadoria, e orientação.

\section{Palavras-chave}

Aprendizagem Híbrida; Aprendizagem Adaptativa; Curadoria, Design e Orientação; TIC e Educação; Formação Inicial de Professores. 


\section{Abstract}

Andrade, Jéssica Zacarias de. Campos. Gilda Helena Bernardino de (Advisor). Blended and Adaptive Learning: Paths in the Relationship Between Education and Technologies. Rio de Janeiro, 135p. Tese de Doutorado - Departamento de Educação, Pontifícia Universidade Católica do Rio de Janeiro.

In the digital society emerge educational approaches mediated by digital technologies that aim to respect the time, pace and form of learning of each student individually. The main ideas embedded in the logic of blended and adaptive learning - autonomy, student protagonism, customization, monitoring and continuous evaluation of learning - are not new and are also present in traditional classroom-based education. The main difference lies in the fact of recognizing in technology the potential of expanding the forms and places of learning, providing a parallel and integrative way, not substitutive and not simply complementary to face-to-face teaching, in order to achieve learning objectives. The general objective of this research is to present the conception, operationalization and implications of two educational approaches mediated by digital technologies, blended learning and adaptive learning. The thesis was structured in the multipaper format containing three independent studies that safeguard thematic unit and theoretical alignment, thus maintaining an interrelation. The adoption of an alternative model for writing the thesis responds to the demand for the research object, which is plural, diffuse and multifaceted. The first study, a systematic survey of the literature from the academic production in the area of Informatics in Education, sought to identify the conceptions and characteristics of hybrid and adaptive models that aim at personalization of learning. The second study is the report of an online training experience for teachers that sought to explore the concepts of blended and adaptive learning, as well as to mobilize mechanisms for its operationalization. The third study aimed to verify, from the teachers' perception of the degree programs and the curriculum analysis of their courses, if the initial teacher training is in line with the emerging educational approaches mentioned above, as well as their intertwining 
with specific and complementary public educational policies, which aim to promote the incorporation of digital technologies into education. This work has also an introduction, where the theoretical and conceptual framework of the three studies is presented, as well as a conclusive synthesis, presenting an integrated discussion of the results. The research results show the need for greater interaction between professionals in the areas of Informatics and Education in the development of environments and systems that support personalized learning, which implies in the accomplishment of more experimental research and, mainly, in the reconfiguration of the teacher training in order to effectively prepare teachers to play their role, which is no longer a transmitter of knowledge but a mediator in the learning process, re-signifying its modus operandi based on the principles of curatorship, design and orientation .

\section{Keywords}

Blended Learning; Adaptive Learning; Curatorship, Design and Guidance; ICT in Education; Teacher Training. 


\section{Sumário}

INTRODUÇÃO 13

Contextualização 13

Questões e Objetivos da Pesquisa 14

Justificativa 15

Enquadramento Teórico-Conceitual 19

Blended Learning ou Aprendizagem Híbrida 19

Adaptive Learning ou Aprendizagem Adaptativa 25

Engajamento Digital, Produção de Presença e Mediação 31

Opções Metodológicas $\quad 35$

Pesquisa Exploratória: Levantamento e análise da literatura, pesquisas e documentos produzidos sobre as temáticas aprendizagem híbrida e adaptativa. $\quad 37$

[Estudo 1] Pesquisa Bibliográfica: Revisão Sistemática da Literatura 37

[Estudo 2] Pesquisa Descritiva: Relato de Experiência 40

[Estudo 3] Pesquisa de Campo: Análise Documental e Questionário 41

O Formato e a Estrutura da Tese 43

1. Estudo 1 - Aprendizagem Híbrida e Adaptativa no Brasil: Uma Revisão Sistemática das Publicações do Simpósio Brasileiro de Informática na Educação entre 2013 e 2017

1.1. Introdução 45

1.2. Metodologia 46

1.3. Referencial Teórico-Conceitual 49

1.3.1. Aprendizagem Híbrida 49

1.3.2. Aprendizagem Adaptativa 51

1.3.3. Ambientes Virtuais de Aprendizagem (AVA) ou Learning Management Systems (LMS) 51

1.3.4. Sistemas de Recomendação (SR) 52

1.3.5. Sistemas Hipermídia Adaptativos (SHA) 53

1.3.6. Sistemas Tutores Inteligentes (STI) 53 
1.5. Análise e Discussão dos Resultados 56

1.6. Considerações Finais 63

2. Estudo 2 - Abordagens Educativas Emergentes: Explorando

Conceitos

2.1. Introdução

66

2.2. Metodologia

2.3. Engajamento Digital, Produção de Presença e Mediação em Modelos Híbridos e Adaptativos

2.4. O Curso "Aprendizagem Híbrida e Adaptativa: Teoria e Prática" 70 2.4.1. Google Sala de Aula 71

2.4.2. Estrutura do Curso 74

2.5. Discussão e Análise dos Resultados 75

2.6. Considerações Finais 85

3. Estudo 3 - Formação Inicial de Professores na Era Digital: Desafios e Potencialidades para a Adoção de Modelos Educativos Híbridos e Adaptativos

3.1. Introdução

3.2. Metodologia

3.3. Políticas Públicas de Tecnologia e Formação Inicial de Professores no Brasil

3.4. A Tecnologia no Currículo da Formação Inicial de Professores

3.5. Percepções de Professores Formadores Sobre as Tecnologias

Digitais na Formação Inicial Docente 
4. Síntese Conclusiva

4.1. Respondendo às Questões da Pesquisa

4.2. A Tríade Paradigmática da Formação Docente na Era Digital:

Curadoria, Design e Orientação

4.3. A Pesquisa em Perspectiva: Novas Questões e Trabalhos Futuros122

5. Referências Bibliográficas

6. ANEXO

129 


\section{INTRODUÇÃO}

\section{Contextualização}

Ao iniciar o curso de Mestrado em Educação na PUC Rio, meu intuito era investigar a inserção e uso das tecnologias da informação e comunicação (TIC) nas escolas; o problema se apresentava de forma clara, mas o objeto de pesquisa ainda precisava ser delimitado. Após uma aula com a professora Gilda Campos, na qual esta apresentou seu trabalho no curso de especialização a distância em Tecnologias em Educação - realizado pela Coordenação Central de Educação a Distância CCEAD/PUC Rio, em parceria com o Departamento de Educação e a antiga Secretaria de Educação a Distância - SEED/MEC, atual SEB/MEC, percebi que este poderia ser um rico caminho para minha investigação. Os objetivos do curso eram "ampliar o conceito de educação mediada e integrada por tecnologias com a incorporação de todos os meios tecnológicos cabíveis, formando professores para a utilização desses meios (...) e promover a formação continuada dos docentes no uso das TIC no Ensino Fundamental e Médio das redes públicas, para a melhoria progressiva da qualidade da educação básica". (PUC/CCEAD, 2009).

A partir de então me vinculei ao grupo de pesquisa Cooperação e Avaliação em Educação a Distância (EaD). A dissertação “A inserção e o uso das TIC nas escolas públicas do estado do Rio de Janeiro - estudo de caso com os concluintes do curso de pós-graduação lato sensu "Tecnologias em Educação", apresentou resultados, corroborados por outros estudos, tais como: (a) a inserção das TIC nas escolas públicas é um processo irreversível e vem acontecendo gradualmente nas escolas do estado do Rio de Janeiro, com a implantação do aparato tecnológico nas escolas e formação continuada de professores para o uso de tal estrutura; (b) os egressos do curso fazem uso de diferentes suportes e recursos tecnológicos para a preparação de aulas e em sala de aula, sendo que o uso destas tecnologias com os alunos ainda é incipiente.

Estes resultados suscitaram as primeiras questões mobilizadoras da pesquisa de doutorado: será realmente necessário que o professor leve diretamente os suportes e recursos tecnológicos para a sala de aula para que tenhamos o efetivo uso das TIC nas escolas e apropriação das mesmas pelos alunos? Um caminho possível para a efetiva aplicação das tecnologias à educação pode prescindir, porém sem substituir, a utilização do espaço da sala de aula e até mesmo da escola? Quais 
são as propostas existentes no cenário atual? A formação inicial prepara os futuros docentes para integração de tecnologias à educação?

Neste contexto emergem abordagens educativas mediadas pelas tecnologias digitais que atuam numa perspectiva híbrida de aprendizagem, alternando momentos presenciais e a distância e cuja premissa é a adaptação - o respeito ao tempo, ritmo e a forma como o aluno aprende. No Brasil as iniciativas de utilização destes ambientes - públicas e privadas - ainda se encontravam em estágio inicial quando esta pesquisa foi iniciada o ano de 2014, com presença mais fortemente marcada no Ensino Superior. Buscando aprofundamento do conhecimento do campo, entrei em contato com o trabalho realizado pela professora Guilhermina Miranda, da Universidade de Lisboa, que apresenta uma importante interlocução com os objetivos desta investigação, fazendo com que iniciássemos uma parceria, resultando em um período de quatro meses de estágio sanduíche, com o objetivo de aprimorar o referencial teórico - metodológico da pesquisa.

\section{Questões e Objetivos da Pesquisa}

A partir das inquietações originadas com os resultados da pesquisa de mestrado, a investigação de doutorado foi delineada a partir de uma questão central que se desmembra em três questões norteadoras:

Questão Central: Quais os limites e possibilidades das tecnologias digitais na educação?

1. Como são concebidos e como funcionam os sistemas informáticos que consubstanciam a adoção de modelos educacionais híbridos e adaptativos?

2. Como se constituem teoricamente e como se operacionalizam na prática as aprendizagens híbrida e adaptativa, entendidas como abordagens educativas emergentes mediadas pelas tecnologias digitais?

3. A formação inicial de professores contempla em seu currículo e adota em suas práticas estas abordagens educativas emergentes mediadas pelas tecnologias digitais? De que forma?

O objetivo geral desta investigação é apresentar a concepção, operacionalização e implicações de duas abordagens educativas mediadas pelas tecnologias digitais, a aprendizagem híbrida e a aprendizagem adaptativa. Para responder a cada uma das questões norteadoras foram realizados três estudos independentes porém complementares com objetivos específicos. O primeiro estudo, uma revisão 
sistemática da literatura a partir da produção acadêmica na área de Informática na Educação, buscou identificar as concepções e características de modelos híbridos e adaptativos que objetivam a adaptação/personalização da aprendizagem, ou seja, o respeito ao tempo, ritmo e forma de aprendizagem individual. O segundo estudo é o relato de uma experiência de formação online destinada a professores que procurou explorar os conceitos de aprendizagem híbrida e adaptativa, assim como mobilizar mecanismos para sua operacionalização. O terceiro estudo pretendeu verificar, a partir da percepção de professores das licenciaturas e da análise dos currículos de seus cursos, se a formação inicial de professores está alinhada às abordagens educativas emergentes supracitadas, assim como seu entrelaçamento com as políticas públicas educacionais, específicas e complementares, que visam a promoção da incorporação das TIC à educação. Para realizar a investigação dentro deste campo, apresento a seguir a justificativa para a realização da mesma, identificando a problemática a que ela se refere junto ao contexto no qual se inscreve, seu referencial teórico-conceitual, sua proposta metodológica, seu formato e estrutura.

\section{Justificativa}

Entender o contexto onde as questões supracitadas se inserem é de fundamental importância no processo de construção do objeto de pesquisa. Neste espaço, a ideia é apresentar, de forma preliminar, alguns constructos que emergem no cenário atual, no tocante a relação educação e tecnologias.

Para José Cordeiro ${ }^{1}$ passamos por um momento revolucionário, onde o fácil e gratuito acesso ao conhecimento produzido no mundo, com o barateamento da tecnologia e o acesso amplo e gratuito à internet, como na proposta do projeto Loon da Google - se apresenta como uma realidade cada vez mais próxima. Os MOOCS (Massive Open Online Courses) seriam uma das mais claras manifestações desta nova realidade. Cursos universitários online, gratuitos e disponíveis a qualquer indivíduo com acesso à internet, com a possibilidade de certificação após a conclusão dos mesmos, cada vez mais parecem tentar romper a barreira entre ensino presencial e a distância, trazendo à tona com mais força - na medida em que estes cursos são oferecidos por universidades renomadas e de prestígio internacional - 
um novo formato ou uma nova proposta para o processo de ensino- aprendizagem: o blended learning. A expressão em inglês que designa a ideia de uma aprendizagem híbrida, onde parte do processo de ensino-aprendizagem ocorre em ambientes virtuais de aprendizagem e parte em salas de aula físicas, como no modelo tradicional. Neste ponto, algumas questões se impõem: (a) qual formato de e-learning deve ser adotado nesta proposta? (b) em quais pressupostos se baseará, visto que não se trata de uma modalidade estruturada somente em ambientes virtuais, como na educação a distância - campo onde já existe uma farta bibliografia que justifica e apoia as opções didático-pedagógicas dos diferentes cursos existentes ao redor do mundo - mas sim de e-learning entendido como um dos componentes concorrentes na promoção da aprendizagem?

Para chegar a um modelo de e-learning, no contexto da aprendizagem híbrida, a discussão passa necessariamente pela análise de alguns movimentos direcionados ao entendimento do funcionamento do cérebro humano, encarando-o, como afirma Cordeiro, como o órgão da educação, da aprendizagem humana. Este é um desafio a que se propõem algumas iniciativas internacionais como o Brain Initiative nos Estados Unidos e o Blue Brain Project na Suíça, entre outras. A tentativa de entender cada vez mais os diferentes processos engendrados à cognição humana é melhor compreendida quando se avança na discussão do papel das tecnologias aplicadas à aprendizagem no contexto da aprendizagem híbrida. Uma das utilizações mais recorrente das tecnologias nesse contexto são as chamadas plataformas adaptativas, que tem como objetivo não somente permear o processo de ensino-aprendizagem, mas principalmente oferecer subsídios de forma rápida e eficaz a tudo o que envolve este processo. $\mathrm{O}$ intuito destes ambientes, tomando como exemplo a escola, é permitir que os estudantes possam identificar claramente seus pontos de fragilidade na compreensão de diferentes conteúdos; que os pais possam acompanhar diretamente e em tempo real a evolução dos filhos na escola; que os professores possam monitorar e intervir de forma personalizada e contínua na aprendizagem dos alunos; que os diretores tenham a possibilidade de saber exatamente como a escola está caminhando, tudo em tempo real. As principais ideias embutidas na lógica da aprendizagem híbrida e adaptativa - autonomia, protagonismo do aluno, personalização do ensino, acompanhamento e avaliação contínua da aprendizagem - não são novas e também estão presentes na educação tradicional exclusivamente presencial. A principal diferença reside no fato de 
reconhecer na tecnologia o potencial de expansão das formas e lugares de aprendizagem dos alunos, oportunizando uma via paralela e integradora, não substitutiva e nem tampouco de caráter simplesmente complementar ao ensino presencial, para alcance dos objetivos de aprendizagem. Quanto ao elemento 'diferentes formas de aprendizagem', é importante salientar que este se constitui como um pilar que confere sustentabilidade à proposta de aprendizagem híbrida e adaptativa, na medida em que vislumbra na tecnologia a viabilidade de personalização do ensino, possibilitada pela uso de inteligência artificial.

No Brasil já temos alguns indicadores oficiais que apresentam a correlação entre o uso de plataformas adaptativas e o desempenho dos alunos, visto que a Secretaria Estadual de Educação de São Paulo em 2015 adotou para as turmas de $3^{\circ}$ ano do Ensino Médio a plataforma Geekie, com o intuito de preparar os alunos, de forma personalizada, para o Exame Nacional do Ensino Médio (ENEM). No ano de 2016, o governo federal também estabeleceu pareceria com a Geekie e lançou a plataforma Hora do ENEM, assim como o repositório de vídeos MECFLIX, com o intuito de oportunizar aos alunos regularmente matriculados no $3^{\circ}$ ano do Ensino Médio uma preparação personalizada para o exame. Dados disponibilizados pela equipe de relações públicas da Geekie informam que 4,5 milhões de estudantes utilizaram a plataforma, o equivalente a $57 \%$ do universo de candidatos ao Enem em 2016 e que, em média, alunos que usaram a plataforma dedicaram 57 minutos diários aos estudos, sendo o padrão nacional para o uso do Facebook de 44 minutos diários. Uma avaliação de impacto realizada pela consultoria Metas Sociais atestou que alunos que seguiram o plano de estudos personalizado na sua totalidade tiveram uma evolução cinco vezes maior do que aquela obtida por estudantes com mesmo grau de engajamento mas que não se guiaram pela tecnologia adaptativa. Esta comparação foi possível pois apenas estudantes matriculados no $3^{\circ}$ ano do Ensino Médio tinham acesso a todos os recursos da plataforma, enquanto os demais inscritos não acessavam os recursos adaptativos. A avaliação também identificou, a partir do cruzamento de dados sobre o acesso à plataforma e notas do simulado oficial do MEC, que os alunos de escolas públicas que estudaram regularmente pela plataforma apresentaram a tendência para a obtenção de um ganho médio 15,5\% maior do que os alunos da rede privada.

Entre as iniciativas e a pesquisa na área parece, no entanto, haver um hiato. Em uma revisão de literatura realizada por Rosado et al. (2017) sobre a produção 
científica em Educação e Tecnologias, onde foram selecionados 193 artigos publicados em 28 revistas qualificadas no estrato “A” do Qualis CAPES Educação e se procurou identificar tendências na concepção de tecnologia na educação, os resultados indicaram que a inclusão de tecnologias em contextos educacionais não apresenta mudanças na dimensão didático-pedagógica, se manifestando apenas como mudança de suporte para as práticas já executadas. Dois apontamentos feitos pelos autores, o primeiro acerca da fragilidade teórico-metodológica que consusbtancia algumas pesquisas e o segundo, relativo a perspectiva de muitos estudos, que se limita ao contraste antes e depois da inserção das tecnologias, leva a duas reflexões: a primeira sobre os problemas decorrentes da precariedade do rigor metodológico na pesquisa educacional, fator já levantado por Gatti (2004), especialmente quando se trata da realização de estudos com abordagem quantitativa e a segunda, extensão da primeira, mostra o quanto a falta de rigor metodológico interfere na qualidade e impacto das pesquisas realizadas no âmbito da interface educação e tecnologias, na medida em que a avaliação do impacto da introdução das tecnologias na educação - nas práticas pedagógicas, na adoção de novas metodologias e na aprendizagem dos alunos - não é contemplada por boa parte dos estudos analisados.

Ao escolher um objeto de estudo que permeia áreas distintas, mas que devem convergir e se constituir em um novo campo de ação e pesquisa, é preciso compreender quais são as lentes usadas por estes atores, analistas de sistemas e educadores, para compreender o mundo. É necessário um exercício no sentido de alcançar qual entendimento sobre ciência, educação e tecnologias digitais estes possuem. Identificar as confluências e divergências de pensamento acerca destas questões é essencial para caminhar na direção da legitimação e consolidação de um campo de investigação e prática para além da interface de dois mundos, rumo à uma conjugação, que combine os elementos primordiais de cada área de conhecimento. Desta forma, se ultrapassará a ideia de educação de/para/com tecnologias para se pensar em educação, uma educação pensada e executada de acordo com a realidade e o contexto em que está inserida. Ora, se vivemos em uma "era digital” a educação, por sua vez, também é digital, e isto não é apenas mais uma de suas facetas, é intrínseco e situado. Este se apresenta como um campo profícuo para a pesquisa em educação e tecnologias, entendendo que os novos laços estabelecidos entre estas duas áreas requerem uma averiguação aprofundada, na medida em que todos os 
esforços empreendidos têm como objetivo final a melhoria da qualidade na educação, resultado da combinação de uma formação docente e métodos de ensinoaprendizagem eficazes.

\section{Enquadramento Teórico-Conceitual}

Nesta seção são apresentados e discutidos os conceitos-chave da pesquisa: Aprendizagem Híbrida; Aprendizagem Adaptativa; Engajamento Digital; Produção de Presença e Mediação, de modo a constituir um referencial teórico-conceitual transversal aos três estudos que compõe esta tese.

\section{Blended Learning ou Aprendizagem Híbrida}

A revolução tecnológica trouxe transformações profundas à sociedade, configurando uma arquitetura em rede, composta por milhares de nós, onde a tomada de decisão é descentralizada (Monteiro, Moreira e Lencastre, 2015). Neste cenário, cabe à escola compreender e atuar a partir destas potencialidades, mas especificamente o protagonismo e a autoria que podem ser promovidos, resguardando as singularidades que o processo educativo pressupõe. A tecnologia per si não acarreta nenhuma mudança significativa, seja nos espaços formais ou informais de aprendizagem. Somente na esfera da apropriação das tecnologias, em termos didático-metodológicos, é que se pode perceber suas potências e limitações. Em uma sociedade onde o virtual e o presencial cada vez mais se conjugam, é de se esperar que a escola e a universidade construam caminhos no sentido de constituir um modelo híbrido de educação, que atenda às necessidades pedagógicas e sociais. Não se trata de uma mera alternância entre as modalidades de ensino presencial e a distância, mas sim uma nova abordagem educativa que emerge, onde "alcançamos o conforto da presença física e exploramos todo o potencial das aprendizagens em rede, mediadas pelas tecnologias" (Monteiro, Moreira e Lencastre, 2015, p.8), ainda poderia se incluir a apreensão de uma nova dimensão estética. Em suma, os espaços escolares não podem se manter apartados e em oposição ao modelo de sociedade híbrido vigente. O primeiro passo é repensar a separação entre espaço formal e informal de aprendizagens. Isto não decreta o fim da escola/universidade, mas uma ressignificação profunda da sua estruturação e modus operandi. O segundo passo, a ser realizado em paralelo ao primeiro, é investigar o quanto e como os investimentos em formação docente impactam na 
integração das TIC nas escolas e universidades. O modus operandi docente deve ser realinhado no sentido de implementar novas formas de gerir a sala de aula, o que, basicamente, será consequência da emergência de novas (ou renovadas) pedagogias, onde o componente tecnológico se funde às mesmas, fazendo parte destas e não aparecendo como algo apartado a ser integrado. Esta discussão será aprofundada no terceiro estudo que compõe esta tese.

Um ponto em comum encontrado entre os autores que discutem a temática (Driscoll, 2002; Garrison e Kanuka, 2004; Graham, 2006; Mcdonald, 2008; Tori, 2009; Christensen, Horn e Staker, 2013; Valente, 2014; Monteiro, Moreira e Lencastre, 2015; Horn e Staker 2015; Moran, 2015; Bacich, Neto e Trevisani, 2015) é o de que o ensino híbrido pressupõe a flexibilização de tempos e espaços, onde momentos presenciais e online são combinados, integrando, assim, espaços físicos e virtuais.

Driscoll (2002) explora o conceito de blended learning a partir de quatro manifestações: (i) combinação de tecnologias baseadas na Web; (ii) combinação de teorias e métodos de ensino-aprendizagem; (iii) combinação de tecnologias educacionais com aprendizagem dirigida e (iv) integração de tecnologias educacionais/corporativas com atividades de trabalho reais, apresentando um caráter multifacetado para o termo, depreendendo-se assim que, a depender do contexto de aplicação, diferentes combinações podem ser compreendidas como modelos de aprendizagem híbrida. Na contramão, Graham (2006) adota uma perspectiva mais restrita, que busca especificar o conceito dentro de sua característica essencial que é a combinação dos modelos de educação presencial e a distância, até então entendidos como modalidades de ensino distintas. Macdonald (2008), acrescenta que a abordagem híbrida surge como resposta ao que chama de um sentimento geral de desilusão com a adoção independente da mídia online como formato único para o desenvolvimento do processo de ensino-aprendizagem. A sensação de incompletude, como consequência da adoção de modelos de educação exclusivamente a distância, reforçou a ideia - que Gourlay (2013) afirma que ainda existe, ao propor o conceito de engajamento digital que será discutido adiante -, de oposição entre a educação presencial e a educação a distância, como duas modalidades apartadas. Sendo assim, a aprendizagem distribuída proposta em uma abordagem híbrida, tem como característica essencial a convergência de interesses entre as aprendizagens que ocorrem nos momentos presenciais e online. 
Sharma (2010) relembra que o conceito de blended learning tem sua origem no mundo corporativo e que, em parte, foi adotado como estratégia para economia de custos, destacando que no contexto educacional, sua aplicação está atrelada à três concepções: (i) combinação de ensino presencial e online, o conceito originário (ii) combinação de tecnologias, que pode ocorrer em modelos totalmente a distância, com o uso de um mix de mídias e recursos digitais, onde a comunicação entre alunos e tutores se dá por diferentes meios digitais, o que implica repensar o papel do professor nesse contexto, assim como todo processo de mediação pedagógica que prescinde da presença física mas se reconfigura na virtualização da presença, conceito que será discutido posteriormente a partir de Gumbrecht (2010) e (iii) combinação de metodologias, que pode ocorrer em modelos totalmente presenciais, onde se lança mão de diferentes abordagens pedagógicas e estratégias didáticas, independentemente das tecnologias de aprendizagem utilizadas.

Garrison e Kanuka (2004) apresentam uma contribuição para a discussão das implicações da aprendizagem híbrida no Ensino Superior, ressaltando que, a partir do momento em que o online passa a permear o processo de aprendizagem, professores são compelidos a confrontar as sólidas concepções de ensino e aprendizagem existentes neste nível de ensino, assim como gestores precisam repensar estratégias que atendam às demandas de uma sociedade digital, na medida em que as novas formas de comunicação e a habilidade de lidar com um grande volume de informações desafiam nossa capacidade cognitiva e o paradigma da sala de aula tradicional. No relatório "An avalanche is coming". Barber, Donnelly e Risvy (2013) corroboram a premência na adoção de medidas transformadoras no Ensino Superior, que devem ser abraçadas por todos os atores envolvidos, de estudantes a governantes, sob pena de, se não o fizerem, uma avalanche de mudanças varrer o sistema.

Horn e Staker (2015) definem que o ensino híbrido passa a se constituir em programas de educação formal, a partir de uma perspectiva de aprendizagem integrada, nos quais os alunos aprendem em parte em local físico, sob supervisão e em parte por meio do ensino online, com algum elemento de controle dos alunos sobre o tempo, lugar, modo e/ou ritmo da aprendizagem, sendo esta a característica fundamental para que se configure uma abordagem híbrida. Os autores identificam quatro modelos de ensino híbrido; (i) o modelo de rotação, cujas metodologias mais disseminadas são a rotação por estações e a sala de aula invertida; (ii) o modelo 
flex, baseado no ensino online e nas necessidades de aprendizagem individuais; (iii) o modelo à la carte, onde algumas disciplinas de cursos presenciais são ofertadas integralmente a distância e (iv) o modelo virtual enriquecido, onde sessões de aprendizagem presencial são complementadas por atividades realizadas a distância. Tanto o modelo à la carte quanto o virtual enriquecido são contemplados, por exemplo, por cursos no formato semipresencial - o que na perspectiva de Garrison e Kanuka (2004), não caracterizariam uma abordagem híbrida -, como em cursos de graduação e pós graduação presenciais que operam segundo a legislação brasileira que regulamenta a educação a distância no Brasil $^{2}$ e permite que parte da carga horária do curso seja oferecida a distância.

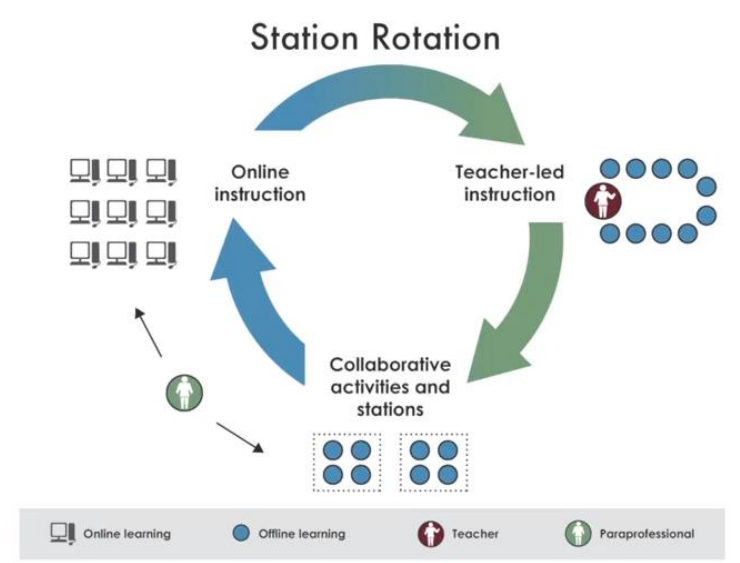

Figura 1: Rotação por estações. Fonte: Material didático do curso "Blended Learning", oferecido pelo Coursera.

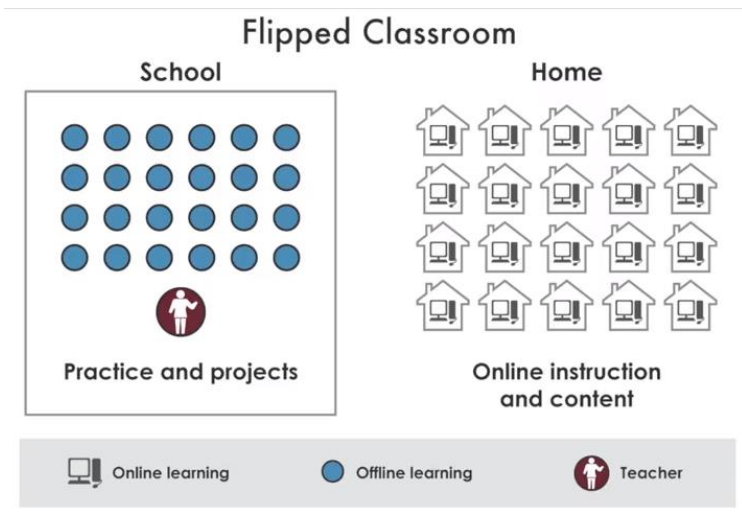

Figura 2: Sala de Aula Invertida. Fonte: Material didático do curso "Blended Learning", oferecido pelo Coursera.

${ }^{2}$ Portaria 4.059/2004 do MEC. 


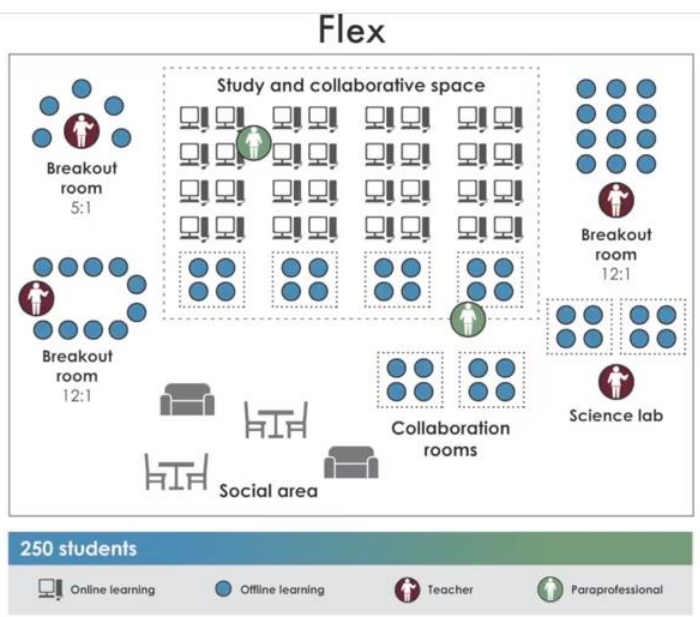

Figura 3: Modelo flex. Fonte: Material didático do curso "Blended Learning", oferecido pelo Coursera.

No cenário brasileiro, Valente (2014) destaca que as tecnologias promoveram mudanças substanciais, em termos de adoção e utilização de diferentes concepções teóricas, abordagens pedagógicas e processos de avaliação da aprendizagem, primeiramente na $\mathrm{EaD}$, visto que, até o final da década de 1980, havia uma separação espacial e temporal entre professor e aprendizes claramente marcada, o que é transformado com a utilização de tecnologias síncronas e assíncronas. Para o autor, a combinação do que ocorre online com o que ocorre em sala de aula presencialmente pode ser muito rica e beneficiar a aprendizagem dos alunos sob diferentes aspectos, destacando por exemplo, que a adoção do modelo de sala de aula invertida faz com o aluno chegue à sala de aula com o conhecimento factual necessário e use o espaço presencial para desenvolver formas mais elevadas de trabalho cognitivo, como a aplicação, análise, síntese, significação e avaliação do conhecimento, que diante de uma perspectiva vygotskyana, demandam a orientação do professor e a interação com os pares ancorada na noção de par mais capaz. Porém, o autor ressalta que a adoção deste modelo depende de forte adesão dos alunos e de condições equânimes de acesso à tecnologia, em especial à internet. Moran contribui com a discussão (2015) ao definir o ensino híbrido como um conjunto de saberes e valores, metodologias ativas e tecnologias híbridas, que suportam um currículo flexível, prevendo a articulação entre ensino formal e informal, com a integração de diferentes áreas e pessoas, tempos e espaços. Tori (2009) complementa, destacando que do encontro da sala de aula presencial com os ambientes virtuais de aprendizagem surgem os cursos híbridos, que levam em consideração os seguintes aspectos para sua composição: o contexto, o custo, a 
adequação pedagógica, os objetivos educacionais e perfis discentes. O autor também levanta a questão relativa à dicotomia distância versus presença, apontando que com as possibilidades de interação disponíveis pela via digital, "mais importa a 'sensação' de presença percebida pelo aluno que a efetiva distância física entre ele e seu professor". (Tori, 2009, p.123). Em consonância às concepções acima mencionadas, o conceito de ensino híbrido preconizado por Bacich, Neto e Trevisani (2015), em sua acepção essencial, tem a ver com a possibilidade de conjugar diferentes espaços, combinar diferentes metodologias e interagir de forma síncrona e assíncrona. Complexificando um pouco mais, o modelo pressupõe um equilíbrio maior no ensino/desenvolvimento de habilidades cognitivas e socioemocionais, assim como contempla aquilo que extrapola as intencionalidades pedagógicas do docente e institucionais. O modelo híbrido precisa buscar, portanto, o equilíbrio entre as dimensões individual e coletiva da aprendizagem, o que deixa claro que a personalização da aprendizagem não é sinônimo de individualização muito menos automação da aprendizagem.

Todas as perspectivas analisadas nos sugerem que a concepção de blended learning, que surge no início dos anos 2000 e, ao longo de sua primeira década tem discussões voltadas para uma definição do conceito, destacando suas potencialidades e limitações, chega à segunda década deste milênio como uma realidade, quando não estabelecida, em vias de se estabelecer, onde já existe um certo consenso quanto à sua delimitação conceitual. As questões que agora emergem estão no campo da prática: como concatenar momentos presenciais e a distância, alinhados aos propósitos institucionais, de forma que assumam o caráter convergente desta abordagem educativa? A figura 4 apresenta uma síntese esquemática das contribuições desta pesquisa acerca da concepção de aprendizagem híbrida, fruto da revisão inicial da literatura que mapeou os principais autores e definições, e da exploração e análise do conceito, a partir da revisão sistemática realizada no primeiro estudo, da experiência relatada no segundo estudo e da percepção dos professores que responderam ao questionário do terceiro estudo que compõem esta tese. 


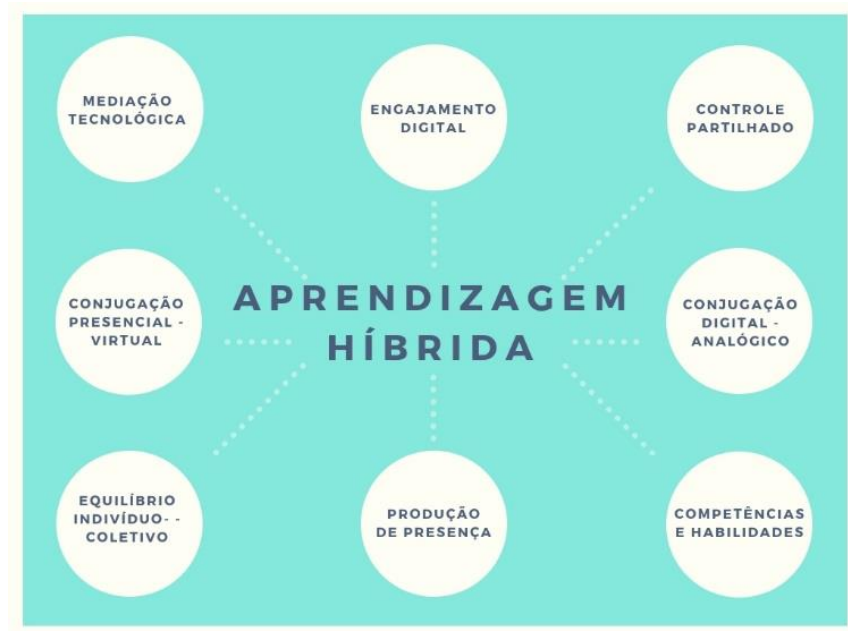

Figura 4: Síntese esquemática das contribuições da pesquisa acerca da concepção de aprendizagem híbrida. Fonte: autoria própria.

\section{Adaptive Learning ou Aprendizagem Adaptativa}

A proposta ensejada na concepção das plataformas adaptativas é de que as mesmas sejam capazes de aprender sobre os estudantes, podendo assim adaptar os conteúdos e/ou percursos formativos de forma personalizada, otimizando o tempo, reduzindo custos e se valendo da mediação pedagógica de professores somente quando necessário. Os sistemas de recomendação, os sistemas hipermídia adaptativos e os sistemas tutores inteligentes são os mais utilizados para promover aprendizagem adaptativa/personalizada. O infográfico a seguir (Figura 5) traz uma definição e explicita as implicações que a adoção de uma plataforma adaptativa traz para o processo de ensino-aprendizagem, especialmente no que tange a reconfiguração dos papéis de aluno e professor. 


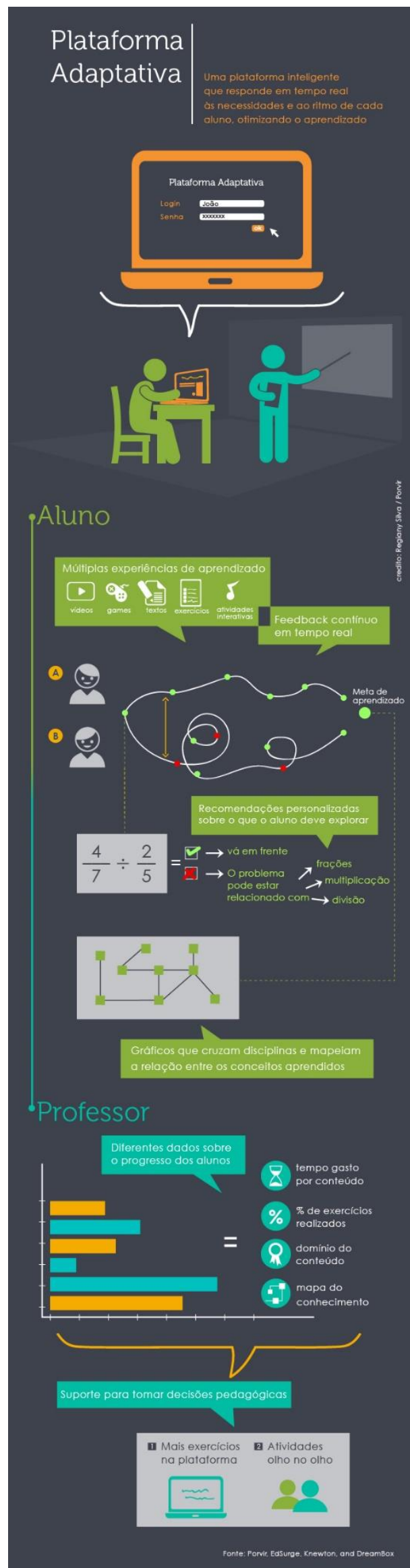

Figura 5: Infográfico Plataformas Adaptativas. Fonte: www.porvir.org. 
Como ressaltam Gavidia e Andrade (2003), o processo de recomendação na educação - e poderia se afirmar o mesmo para o processo de adaptação na educação - não pode ser baseado apenas nos gostos, interesses e histórico de utilização do usuário, exige modelos e uma composição de critérios para a recomendação específicos que visem a potencialização do processo de aprendizagem, adequandose aos objetivos de aprendizagem e exigências curriculares, por exemplo.

Segundo Weibelzahl (2001) o princípio básico dos sistemas adaptativos é adquirir informações sobre seus usuários afim de aferir características abstratas, também chamadas de propriedades do usuário, e assim decidir como adaptar, o que impacta tanto no comportamento do usuário quanto do sistema, sendo esta última a principal diferença destes para os sistemas de recomendação educacionais. De acordo com Brusilovsky (2001) os principais componentes de um sistema hipermídia adaptativo são: (i) o modelo de usuário, responsável por representar o conhecimento do usuário; (ii) o modelo de adaptação, responsável pela seleção de estratégias pedagógicas a serem utilizadas de acordo com os dados provenientes do modelo de usuário; (iii) o modelo de domínio, responsável pelo gerenciamento do material didático-instrucional a ser apresentado ao usuário e (iv) o modelo de interface, mecanismo de interação entre o sistema adaptativo e seus usuários. Os sistemas tutores inteligentes, que remontam a década de 1980, possuem formatação similar aos sistemas hipermídia adaptativos, com (i) o modelo de aluno, módulo que representa o conhecimento e as habilidades cognitivas do aluno em um dado momento; (ii) o modelo de domínio, que contém as informações que o sistema possui sobre o domínio que se deseja ensinar ao aluno (iii) o modelo pedagógico, que contém as estratégias e as táticas de ensino e (iv) o modelo de interface que tem a dupla função de apresentar o material instrucional e monitorar o progresso do aluno através da recepção de suas respostas. Seu diferencial, de acordo com Gavidia e Andrade (2003). é a utilização de diferentes técnicas de inteligência artificial na composição dos sistemas e a presença de um modelo pedagógico.

Um fator a ser considerado é até que ponto a modelagem do usuário/aluno, usada na maioria dos sistemas adaptativos, é efetiva, mesmo que respaldada pela construção de modelos de aluno com base em teorias de estilos de aprendizagem. Esta questão se impõe pois todo o percurso de aprendizagem do aluno passa a ser orientado sob a crença de que o mesmo aprende melhor se o conteúdo for apresentado de maneira adequada ao seu estilo de aprendizagem, indicado por 
questionário respondido antes do início do processo de aprendizagem em si. O objetivo dos questionários de verificação dos estilos de aprendizagem é percepcional, sendo estes elaborados com o intuito de compreender as diferentes maneiras pelas quais aprendemos, após a finalização de uma etapa e/ou percurso de aprendizagem e, assim, pode servir de substrato para reorientar a prática docente, $\mathrm{o}$ gerenciamento pessoal de aprendizagem e o design instrucional de ambientes virtuais de aprendizagem. A prática de utilização destes questionários para construir ambientes adaptativos, utilizando o estilo de aprendizagem como dado a priori, é inadequada, resguardando incompatibilidade com as premissas de Kolb (1984), por exemplo, que ao identificar quatro estilos de aprendizagem, a saber, (i) divergente, (ii) assimilador, (iii) convergente e (iv) acomodador, como preferências na forma de perceber, organizar, processar e compreender a informação, enfatiza que a eficácia da aprendizagem pressupõe um movimento cíclico, onde o aluno percorra os quatro estilos. A partir da definição expressa no trecho abaixo, ficam claras as ideias de um continuum de aprendizagem e da imbricação dos movimentos de percepção, representação e transformação do conhecimento, visto a afirmação de que

\footnotetext{
“(...) a aprendizagem e, portanto, o saber, requer uma captação ou representação figurativa da vivência e alguma transformação dessa representação. A captação figurativa ou a transformação operativa sozinha não é suficiente. A simples percepção da vivência não é suficiente para a aprendizagem, algo deve ser feito com ela. Da mesma forma, a transformação sozinha não pode representar aprendizagem, pois deve haver algo a ser transformado, algum estado ou vivência que esteja em curso". (KOLB, 1984, p. 42)
}

O modelo Felder-Silverman (1988), frequentemente adotado para constituição dos sistemas adaptativos analisados no primeiro estudo desta tese, compreende a aprendizagem como um processo que ocorre em duas etapas, a recepção de informações e o processamento de informações, objetivando identificar as formas preferenciais pelas quais os aprendizes recebem e processam as informações. Os estilos de aprendizagem foram então organizados em quatro dimensões de preferências: (i) sensorial-intuitivo; (ii) visual-verbal; (iii) ativoreflexivo e (iv) sequencial-geral e são avaliados a partir do Index of Learning Styles Questionnaire (ILS), que indica os resultados em três faixas: (i) não há preferência; (ii) existe preferência moderada, o que sugere maior facilidade em aprender quando estilo de aprendizagem de preferência é considerado e (iii) existe preferência forte, o que sugere maior dificuldade na aprendizagem quando o estilo de aprendizagem 
de preferência é desconsiderado. Apesar da inspiração em Kolb (1984), o modelo Felder-Silverman assume uma concepção de aprendizagem limitada à dimensão representacional de apreensão do conhecimento, na medida em que se pauta na recepção e processamento da informação e não contempla a dimensão da transformação dessa representação. Soma-se ainda o fato de que algumas aprendizagens demandariam determinadas características, tal como configuradas nas quatro dimensões do modelo, divergentes do estilo preferencial identificado pelo questionário. Nesse sentido, a identificação dos estilos de aprendizagem não deveria condicionar o processo de aprendizagem dentro dos limites preferenciais, mas sim, estimular o desenvolvimento das características não identificadas, na medida que as mesmas serão requeridas para apreensão de algum conteúdo. Como exemplo para elucidar o que foi dito, um aprendiz cujo estilo de aprendizagem se configura como sensorial-verbal-ativo-geral teria muita dificuldade em se adequar ao modelo de aprendizagem proposto por sistemas adaptativos, na medida em que os mesmos não contemplam, por exemplo, a dimensão colaborativa da aprendizagem e alguns até mesmo prescindem da mediação docente, pois seu objetivo é tornar a aprendizagem mais personalizada e individualizada possível, o que se contrapõe ao perfil do aprendiz. Isto não significa que este aluno hipotético não possa aprender por sistemas adaptativos, ao contrário, deveria ser estimulado a desenvolver características da dimensão individual da aprendizagem, para adquirir as habilidades necessárias na utilização de tais sistemas, que são igualmente importantes para a progressão de uma aprendizagem integral, tais como autonomia, autorregulação e metacognição.

Nessa direção, Siemens (2016) contribui para uma reconstrução do conceito, ao propor um deslocamento, onde se adjetive aqueles que aprendem e não a aprendizagem ou as plataformas, deveríamos portanto falar de aprendizes adaptativos. $\mathrm{O}$ erro das plataformas adaptativas atuais estaria na ênfase dada ao conteúdo e ao currículo, quando deveria estar no aluno. O limite da abordagem atual residiria no fato das plataformas adaptativas focarem em competências e habilidades (product skills), tais como o desenvolvimento de habilidades técnicas e execução de tarefas de rotina, enquanto as demandas para o futuro, com postos de trabalho que ainda não existem e tarefas cotidianas mais complexas, exigiriam que o foco fosse em atributos de processo (process attributes), tais como, trabalhar em grupos, pensar criativamente, autorregulação, definição de objetivos e resolução de 
desafios complexos. Da maneira como funcionam hoje, as plataformas adaptativas se caracterizariam como uma tentativa de fazer mais eficiente um sistema de aprendizagem que não é mais necessário e dispender esforços e energia nisso seria um erro.

Corroborando a visão de Siemens sobre o estado atual das plataformas adaptativas, ao analisar a disposição dicotômica das definições de personalização e customização, assim como dos conceitos de adaptatividade e adaptabilidade (CAYA e NETO, 2016), os limites e possibilidades das tecnologias de adaptação da aprendizagem se apresentam de forma mais clara. Na Figura 6 é demonstrado o caminho percorrido entre a constituição de um sistema adaptativo, que promove personalização, e sua transformação em um sistema adaptável, que permite ao usuário o controle sobre as adaptações, garantindo assim a customização do sistema. Trazendo esta amálgama conceitual para o campo educacional, pode-se depreender que as plataformas adaptativas possuem elementos para personalizar a aprendizagem, de acordo com os parâmetros informáticos. Porém não há nenhum tipo de controle do aprendiz no processo de adaptação, sua única função é fornecer ao sistema informações (inputs), para que o mesmo o devolva conteúdos e percursos formativos (outputs), de acordo com modelos de aluno estabelecidos a priori nos quais os aprendizes tem seu perfil atrelado. Porém a adaptação/personalização concebida em termos pedagógicos, como o respeito ao tempo, ritmo, e forma de aprender individual, se aproximaria mais conceitualmente do termo customização, em especial no que diz respeito ao tempo e ritmo de aprendizagem, cuja customização não poderia ser total no âmbito da educação formal, dadas as restrições impostas por sua organização institucional, com currículos e calendários próprios, por exemplo.

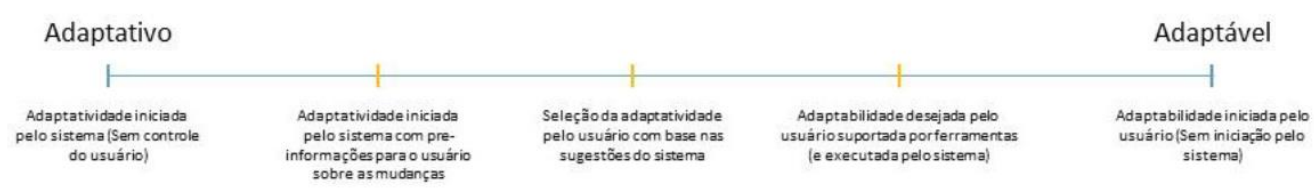

Figura 6: Espectro da relação entre os termos adaptativo e adaptável. Fonte Caya e Neto, 2016, p.57.

A partir da revisão conceitual exposta acima, da análise dos modelos, propostas e experiências relativos à aprendizagem adaptativa na revisão sistemática da literatura (Estudo 1); da experimentação da plataforma adaptativa GeekieLab e 
discussão do conceito de aprendizagem adaptativa na formação online para professores (Estudo 2) e das percepções dos professores que responderam ao questionário sobre possíveis cenários de adaptação da aprendizagem (Estudo 3) foi elaborada a síntese esquemática a seguir, com as contribuições desta pesquisa acerca da concepção de aprendizagem adaptativa.

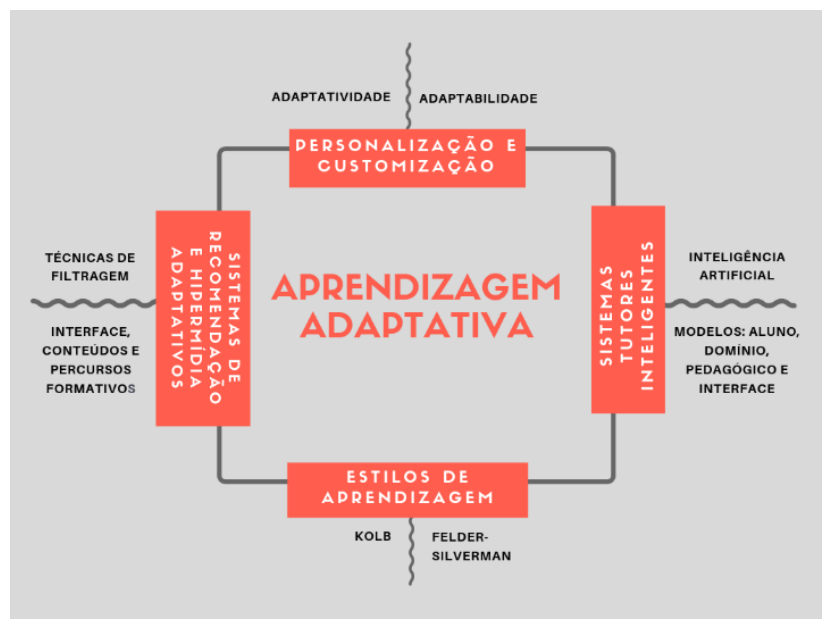

Figura 7: Síntese esquemática da concepção de aprendizagem adaptativa. Fonte: autoria própria.

\section{Engajamento Digital, Produção de Presença e Mediação}

Um perfil de aprendente engajado digitalmente é proposto por Anderson (2007), para quem este transita entre os mundos online e físico, compreende que existem diferentes caminhos e ferramentas a serviço de sua aprendizagem, passando a reconhecer indicadores de qualidade do processo. A enorme quantidade de conteúdos disponíveis somada à ubiquidade da comunicação e seus mais variados agentes se transformam em uma equação cujo resultado é um ambiente profícuo à emergência de uma cultura participatória e de expansão dos contextos educativos.

Gourlay (2017) remonta a perspectiva supracitada e elabora o constructo engajamento digital, configurado como uma prática sócio-material que demanda uma universidade digital concebida em sua relação com o material, ou seja, que precisa ser re-corporificada, na medida em que o “(...) o digital tornou-se entrelaçado à práticas preexistentes, em vez de suplantá-las inteiramente, como é frequentemente afirmado na literatura acadêmica e nas formulações de políticas" (GOURLAY, 2017, p.417). Esta é uma tarefa desafiadora, visto que o paradigma prevalente no Ensino Superior, e poderíamos dizer o mesmo da Educação Básica, consiste na divisão binária entre digital e analógico, quando o caminho para o modelo híbrido, com a profusão de ambientes virtuais de aprendizagem e 
disseminação da perspectiva Bring Your Own Device (BYOD) $)^{3}$, cresce de forma exponencial.

A base do processo de engajamento digital ainda é a linguagem, concreta e analógica, como mostra a Figura 8. Compreendido como prática sociomaterial, é resultado de uma reconfiguração do tempo e do espaço que apresenta desafios e oportunidades. Para além disso, os dispositivos tecnológicos passam a ser considerados elementos ativos, e não somente suportes/ferramentas, visto que o engajamento digital é dialógico e social.

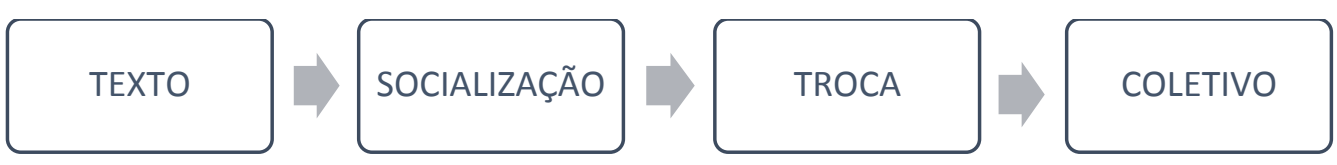

Figura 8: Processo de engajamento digital. Fonte: Elaboração própria a partir de Gourlay, 2017.

A análise sociomaterial do engajamento digital implica, primeiramente, em compreender suas práticas, e também planejá-las, como socialmente situadas, corporificadas e materiais; paralelamente e paulatinamente, desloca-se a agenda de pesquisa para o reconhecimento do digital em combinação com o analógico. A recorporificação do digital pressupõe uma rede de práticas distribuída entre atores humanos e não humanos, onde o lócus de ação é distribuído, mobilizando maior complexidade e interação. (GOURLAY, 2017). Essa re-corporificação está ancorada no conceito de mente corporificada, que propõe a dissolução da ideia de mente separada do corpo e entende o processo de cognição humana no contexto das relações de um corpo físico que interage com o mundo (WILSON, 2002), assim como encontra ressonância no constructo formulado por Andy Clark (2003), de um sistema cognitivo que acople mente individual e ambiente externo - mente estendida -, e que é muito caro ao ancoramento teórico desta pesquisa, já que um ambiente/sistema de gestão da aprendizagem, visto por este prisma, se posicionaria como extensão da mente do aluno, e, nesse sentido estaria em um movimento dialético constante onde as representações simbólicas do ambiente poderiam refletir as representações mentais dos alunos. Esta tríade conceitual relativa a corporeidade da cognição - re-corporificação, mente corporificada e mente estendida - reverbera diretamente no papel do professor em contextos híbridos e adaptativos, visto que

\footnotetext{
${ }^{3}$ Segundo o NMC Horizon Report - Edição Educação Básica 2015, BYOD (Bring Your Own Device), também conhecido como BYOT (Bring Your Own Technology), refere-se à prática de pessoas que levam e fazem uso de seus próprios laptops, tablets, smartphones ou outros dispositivos móveis no ambiente de aprendizagem ou de trabalho. Disponível em: http://ppgtic.ufsc.br/files/2015/11/2015-nmc-horizon-report-k12-PT.pdf.
} 
sua prática precisa ser reelaborarada a partir deste novo paradigma, ressignificando o conceito de presença, que por sua vez, está diretamente atrelado ao de mediação.

Diante do exposto, a opção por discutir o conceito de presença a partir de Gumbrecht (2010) surge da observância de uma articulação intrínseca entre os pressupostos de uma aprendizagem híbrida e adaptativa e a hipótese central das Ciências Cognitivas, pois para se pensar um sistema informático que se adapte ao estilo de aprendizagem, representado pela equação tempo+ritmo+forma de aprendizagem do aluno, é necessário trabalhar com a ideia de representações mentais, consequentemente considerando a aprendizagem apenas em sua dimensão de processamento de informação, que por sua vez está vinculada à tradição hermenêutica e cartesiana, que colocam em segundo plano a dimensão estética, a apreensão do mundo pelos sentidos. A discussão sobre produção de presença, portanto, é justificada por sua capacidade de ancorar teoricamente a identificação de limites e possibilidades na compreensão do mundo mediada pelas tecnologias e sua perspectiva representacional. A aposta de Gumbrecht (2010) na constituição de uma alternativa não hermenêutica para se pensar e compreender o mundo é pautada na materialidade, corporeidade e substancialidade humana. Com o objetivo de restituir ao mundo seu status de 'coisa' é que o conceito de presença se inscreve, na medida que 'coisas' são sentidas, tangíveis, experimentadas e não somente interpretadas e significadas, como preconiza a tradição hermenêutica. Extrair ou atribuir sentido e interpretar fazem parte da experiência humana e não se deve prescindir desses recursos de compreensão dos fenômenos humanos, mas sim conciliá-los à 'substancialidade do Ser'. Em síntese, o que se pretende é estabelecer uma "relação com as coisas do mundo que possa oscilar entre efeitos de presença e efeitos de sentido" (GUMBRECHT, 2010, p.15). Assumindo produção de presença como "eventos e processos nos quais se inicia ou se intensifica o impacto dos objetos 'presentes' sobre corpos humanos" (GUMBRECHT, 2010, p.13), temos uma aproximação ao constructo de mente estendida (CLARK, 2003), segundo o qual somos naturalmente ciborgues, na medida em que nos relacionamos com o mundo através da linguagem - mesmo pressuposto do conceito de engajamento digital -, criando uma conexão entre mente e mundo sempre mediada por diferentes tecnologias. Nossa mente seria estendida ao nosso corpo e ao ambiente que nos cerca, não havendo divisas tal como as preconizadas pelo paradigma cartesiano: mente-corpo e sujeito-objeto. 
Todo este arcabouço teórico acerca dos conceitos de engajamento digital e produção de presença culminam na discussão sobre mediação, onde são redefinidos os papéis do aluno, do professor e das tecnologias em sua relação com o conhecimento. A demanda por uma re-corporificação da cognição anteriormente discutida implica, em termos práticos, que professores e alunos passem a perceber os dispositivos tecnológicos como extensão de suas capacidades cognitivas, que atuam especialmente como uma memória estendida. Ao retomar a origem do termo mediação, em sua utilização no âmbito da educação para designar o papel do professor (Vygotsky, 2010), retrocedemos até Piaget (1975), que apresenta em sua teoria construtivista o deslocamento do papel do professor de transmissor para designer e orientador, na medida em que possui a dupla função de elaborar situações de aprendizagem adequadas ao nível cognitivo de seus alunos e orientá-los durante o processo de equilibração. Sobre os objetivos da educação e o propósito da mediação, Morgado (2005) sintetiza a perspectiva piagetiana, segundo a qual

\footnotetext{
"uma educação para a paz deveria conduzir o sujeito a ultrapassar os seus próprios pontos de vista, tentando compreender as motivações e as razões invocadas pelo adversário, tendo como finalidade atingir a convergência daqueles com base na cooperação e reciprocidade entre todos; tal conduta não passaria, no entanto pela subjugação à opinião alheia mas antes pela construção, em conjunto, de posições novas (Morgado, 2005)
}

Sobre as motivações do outro - designado na figura de adversário em uma perspectiva dialética mas que pode ser compreendido também como interlocutor numa perspectiva sócio-interacionista -, percebe-se a influência da teoria da ação social weberiana, segundo a qual toda conduta humana é dotada de sentido, com uma justificativa subjetivamente elaborada (WEBER, 2000). Na ótica de convergência, que não pressupõe um processo dialético na medida em que não há um enfrentamento de ideias para se chegar ao conhecimento verdadeiro, mas sim, parte do pressuposto da construção em conjunto de novos posicionamentos, vislumbra-se uma aproximação teórica da noção habermasiana de entendimento mútuo, que é resultado da interação dos sujeitos pelo diálogo com o uso de linguagem inteligível que permita a compreensão. Desta forma, o falante expõe a sua pretensão de validade ao escrutínio de seu interlocutor, que pode aderi-la ou não, de acordo com a validade dos argumentos utilizados.

Vygotsky (2010) avança no delineamento do conceito de mediação na medida em que demonstra, ao mesmo tempo, a relação intrínseca e as características 
próprias dos processos de aprendizagem e desenvolvimento, indicando as formas e momentos em que o professor deve agir no processo de aprendizagem de modo a contribuir com o desenvolvimento mental/cognitivo de seus alunos. Ao estabelecer que o professor deve reconhecer o nível de desenvolvimento real do aluno, identificando de maneira diagnóstica os conhecimentos por ele já consolidados, a mediação acontece sob o pressuposto da colaboração na resolução de problemas, que permite ao aluno atingir sua zona de desenvolvimento proximal, onde consegue, com auxílio do professor e/ou dos pares, desenvolver suas potencialidades na solução de problemas. Em suma, o processo de aprendizagem mediada forja a zona de desenvolvimento proximal, o que denota seu aspecto essencial e condicionante do desenvolvimento mental/cognitivo daqueles que aprendem. Nota-se na perspectiva vygotskyana um pressuposto de mediação que fornece pistas sobre como ressignificar o papel do professor na era digital, na medida em que este deve passar a atuar orientado pela diagnose que identifica o estado de conhecimento dos aprendizes antes de iniciar seu percurso de aprendizagem mediado, o que pode ser facilitado pela adoção de sistemas adaptativos. Com base no diagnóstico situacional dos aprendizes/turmas, o professor detecta os momentos em que deve intervir, podendo configurar uma prática docente ancorada em uma abordagem híbrida, que oferece um leque de metodologias e estratégias que os conduzem à diferentes formas e combinações possíveis para uma intervenção efetiva.

\section{Opções Metodológicas}

A discussão sobre metodologia em pesquisa social, especialmente em educação, se apresenta como uma questão fundamental no tocante a legitimação científica das investigações produzidas nesta área do conhecimento humano. Não é raro encontrar pesquisas em educação que parecem se estruturar no "improviso metodológico": não há clareza na exposição da metodologia ou da relação entre os procedimentos de coleta de dados e os instrumentos de análise, entre outros. Conhecer métodos, estratégias, procedimentos e técnicas de pesquisa - inclusive reconhecendo suas especificidades e inter-relações - é essencial para identificar que método(s) o objeto de pesquisa demanda, quais procedimentos se adequam a sua(s) questão(ões) de pesquisa.

Partindo do pressuposto de que "o método escolhido deve se adequar à pergunta 
de uma determinada pesquisa" (Günther, 2006), cabe recuperar as perguntas motivadoras desta investigação: Como são concebidos e como funcionam os sistemas informáticos que consubstanciam a adoção de modelos educacionais híbridos e adaptativos? Como se constituem teoricamente e como se operacionalizam na prática as aprendizagens híbrida e adaptativa, entendidas como abordagens educativas emergentes mediadas pelas tecnologias digitais? A formação inicial de professores contempla em seu currículo e adota em suas práticas estas abordagens educativas emergentes mediadas pelas tecnologias digitais? De que forma? De acordo com a perspectiva de Mayring, Flick e Cols apud Günther (2006) e Becker (2007), o ponto de partida de uma investigação científica deve estar centrado num problema; nesse sentido o problema (e ponto de partida) desta pesquisa é "A formação docente para a adoção de uma abordagem educativa híbrida e adaptativa".

Com estes questionamentos em mente, o próximo passo é pensar em que metodologia ou que abordagem metodológica a investigação demanda. Günther (2006) aponta uma tendência à realização de pesquisas que comportem uma abordagem multimétodo, na qual procedimentos, técnicas e instrumentos de análise quantitativos e qualitativos se revezam e se complementam, ao sabor das necessidades da investigação.

Günther (2006) argumenta que as características atribuídas à pesquisa qualitativa - compreensão como princípio do conhecimento, construção da realidade, descoberta e construção de teorias - podem também ser atribuídas a pesquisa quantitativa, visto que ambas as abordagens visam a compreensão de situações complexas, o que as difere é a maneira de chegar a tal compreensão: criação de categorias explicativas (qualitativa) ou estabelecimento de relações entre variáveis (quantitativo); ambos os processos de pesquisa incluem atividades que constituem um ato social de construção do conhecimento e, qualquer ciência tem como objetivo a construção de teorias.

É preciso salientar que, adotando uma abordagem qualitativa em qualquer etapa do processo de investigação, deve-se estar consciente da influência de crenças e valores, seja do pesquisador ou de qualquer indivíduo envolvido, sobre a mesma. Como até mesmo a abordagem quantitativa não está totalmente livre da influência de crenças e valores, Günther (2006) aponta que a questão "não é se valores influenciam comportamentos e estados subjetivos, inclusive os valores do cientista" 
(...) mas "como lidar com esta influência no contexto da pesquisa". Complementando e ratificando o que diz o autor, acredito que todo pesquisador escolhe investigar algo que tenha interesse pessoal, que o afete de alguma forma. Por isso, há a necessidade de um maior detalhamento dos pressupostos teóricos e do contexto subjacentes à pesquisa. A escolha da metodologia e sua verificação constante através da documentação e explicitação, assim como o controle das variáveis do estudo - que devem ser limitadas a um número manejável em termos de recursos de que dispõe o pesquisador e da disponibilidade dos participantes da pesquisa -, são essenciais para garantir o caráter científico da investigação. Consubstanciada nos pressupostos discutidos por Günther (2006), optou-se pela adoção de uma abordagem qualitativa para responder às questões que se colocaram a cada etapa da investigação. São descritas abaixo as metodologias utilizadas nos três estudos que compõem a tese, discriminadas quanto a seus objetivos e procedimentos.

\section{Pesquisa Exploratória: Levantamento e análise da literatura, pesquisas e documentos produzidos sobre as temáticas aprendizagem híbrida e adaptativa.}

A revisão de literatura, além de consubstanciar teoricamente a investigação, atende a necessidade de uma pesquisa exploratória, que visa mapear o campo, identificando conceitos, categorias e constructos próprios do mesmo, que orientarão as demais opções metodológicas. Nesta fase o objetivo foi identificar o máximo número de abordagens, para tanto, foi realizado um mapeamento sobre os autores/obras/teorias expoentes na discussão sobre aprendizagem híbrida e aprendizagem adaptativa e conceitos correlatos, dos quais se elegeu três para operarem como transversais aos três estudos: engajamento digital (Gourlay, 2017), produção de presença (Gumbrecht, 2010) e mediação (Vygotsky, 2010). (Gatti, 2018) e Martins (2015) compõem o referencial teórico para o tema formação de professores abordado no terceiro estudo.

\section{[Estudo 1]Pesquisa Bibliográfica: Revisão Sistemática da Literatura}

De acordo com Vosgerau e Romanowski (2014), pode-se agrupar os estudos de revisão em dois: as revisões que mapeiam e as revisões que avaliam e sintetizam. As revisões de mapeamento buscam levantar indicadores que fornecem caminhos 
ou referências teóricas para novas pesquisas. As revisões que avaliam e sintetizam podem buscar integrar e agregar resultados de estudos quantitativos ou interpretar as evidências encontradas nos resultados de estudos qualitativos. Esta pesquisa buscou encontrar evidências da utilização das abordagens híbrida e adaptativa no contexto brasileiro, assim como as diferentes formas que assumir. Além disso, alguns dados bibliométricos também foram levantados e analisados, com o intuito de verificar como a pesquisa na área está distribuída pelo país, assim como sua evolução histórica.

Segundo a Campbell Collaboration (2017), uma revisão sistemática tem como objetivo, através de procedimentos claros e previamente estabelecidos que minimizam a criação de vieses e permitem a replicação, encontrar sintetizar e avaliar os resultados das melhores pesquisas disponíveis sobre uma questão/área específica. A revisão deve incluir (i) critérios de inclusão/exclusão de artigos,(ii) uma estratégia de pesquisa explícita e (iii) uma codificação e análise sistemática dos estudos incluídos. A revisão deve partir de uma questão central de pesquisa, que identifique estudos que utilizem fontes primárias que respondem a questão mobilizadora de alguma forma.

Levando em consideração os aspectos acima mencionados acerca da natureza de uma revisão sistemática, para a realização desta pesquisa algumas etapas foram seguidas: (i) formulação das questões de pesquisa, destacando uma questão central e três específicas; (ii) delineamento do escopo da pesquisa; (iii) definição dos critérios de seleção dos trabalhos a serem analisados; (iv) seleção dos trabalhos a serem analisados, a partir de um protocolo de busca e (v) extração, análise e discussão dos dados, através da categorização e classificação dos dados obtidos.

Na primeira etapa, foram formuladas as questões norteadoras da pesquisa, sendo uma questão central e três questões específicas:

Questão Central: Como se apresentam as propostas e experiências de aprendizagem híbrida e adaptativa nas publicações da comunidade acadêmica brasileira de Informática na Educação?

Questão Específica: Quais são os pressupostos pedagógicos ensejados à estas propostas/experiências educacionais híbridas e adaptativas?

Questão Específica 2: Como se deu a evolução histórica de publicações sobre a temática? 
Questão Específica 3: Quais são as instituições que estão desenvolvendo pesquisa na área e quais parcerias interinstitucionais vem sendo estabelecidas?

$\mathrm{Na}$ segunda etapa foi feito o delineamento do escopo da pesquisa, onde optou-se pela análise de comunicações publicadas entre 2013 e 2017, nos anais do Simpósio Brasileiro de Informática na Educação (SBIE), um evento anual promovido pela Comissão Especial de Informática na Educação (CEIE) da Sociedade Brasileira de Computação (SBC) cujos objetivos são divulgar a produção científica nacional e promover a troca de experiências entre os membros da comunidade acadêmica vinculada à área de Informática Aplicada à Educação. $\mathrm{O}$ evento conta com 28 edições e a partir de 2012 passou a integrar o Congresso Brasileiro de Informática na Educação (CBIE), priorizando trabalhos que apresentem a concepção, o desenvolvimento e a avaliação de soluções das Tecnologias Digitais da Informação e da Comunicação para promoção da aprendizagem. ${ }^{4}$ A escolha de apenas um evento como base para recolha de dados da revisão se justifica pelo tipo de análise imersiva que se buscou alcançar, visando a sistematização das evidências através da curadoria das publicações. Com isso, buscou-se obter um panorama das pesquisas mais recentes na área, com foco nos trabalhos realizados por desenvolvedores/usuários de ambientes virtuais de aprendizagem, sistemas de recomendação, sistemas hipermídios adaptativos e sistemas tutores inteligentes, no âmbito da comunidade acadêmica brasileira de Informática na Educação.

Na terceira etapa foram definidos os critérios de seleção dos trabalhos, a saber: (a) trabalhos completos (artigos longos) que apresentam propostas ou experiências com abordagem híbrida e/ou adaptativa, tais como o uso de (i) metodologias didáticas que facilitem a implementação de modelos híbridos de aprendizagem, (ii) sistemas de recomendação, (iii) sistemas tutores inteligentes, (iv) sistemas hipermídias adaptativos e (v) sistemas de gestão e avaliação da aprendizagem (AVA) que se pretendem adaptativos, no sentido de atender as especificidades de aprendizagem de seus usuários. Foram, portanto, selecionados estudos que abordam e documentam aspectos práticos da utilização das abordagens educativas pesquisadas; (b) trabalhos desenvolvidos e realizados por pesquisadores em âmbito nacional.

\footnotetext{
${ }^{4}$ Anais do XXVIII Simpósio Brasileiro de Informática na Educação (SBIE 2017). Disponível em http://www.brie.org/pub/index.php/sbie/article/view/7730/5524.
} 
$\mathrm{Na}$ quarta etapa foram selecionados, segundo os critérios supracitados, 63 comunicações do SBIE - em um universo de 634 comunicações, número total de publicações do evento no período compreendido entre 2013 a 2017. Para fins de seleção, foi feita a leitura de todos os títulos e resumos dos artigos publicados no período selecionado. Em alguns casos, procedeu-se à leitura da introdução e busca no texto por palavras-chave, tais como: híbrido(a), adaptativo(a), personalização, pedagógico(a), teoria, metodologia. A opção pela busca e seleção manual dos artigos, garantindo um foco qualitativo à pesquisa, se deu em virtude da especificidade do tema, que não se apresenta necessariamente de forma explícita nos trabalhos. Nesse sentido a opção por uma curadoria dos textos se apresentou como técnica mais adequada aos fins da investigação, possibilitando extrair o máximo de dados possíveis dos artigos analisados.

Na quinta etapa, procedeu-se à extração dos dados, análise e discussão dos resultados, realizada da seguinte forma: (i) identificação das instituições e parcerias institucionais que promovem experiências educacionais híbridas e adaptativas (ii) classificação das publicações por tipo de abordagem utilizada (híbrida ou adaptativa) e tipo de sistema proposto/desenvolvido (AVA, SR, STI, SHA); (iii) identificação, categorização e análise dos pressupostos pedagógicos ensejados às propostas/experiências de aprendizagem híbrida e adaptativa.

\section{[Estudo 2] Pesquisa Descritiva: Relato de Experiência}

A motivação de Silva (2003) em "criar e professorar um curso [online] para nele exercitar a superação de um problema que emperrou a aprendizagem presencial e agora prejudica igualmente a aprendizagem online: a pedagogia da transmissão" (Silva, 2003, p. 53), foi a mesma que conduziu este estudo a ser estruturado na forma de um relato de experiência. Se a aprendizagem híbrida e adaptativa, tema do minicurso, demanda dos professores uma postura de curadores e não mais de guardiões e transmissores, estes precisam adquirir habilidades e desenvolver estratégias para exercer a docência online, nada melhor que propor um curso neste formato para explorar, não só os conceitos-objetos de estudo, como também os desafios e potencialidades da mediação online, assim como as possibilidades de sua interlocução com a mediação presencial.

Com a adoção dessa opção metodológica. torna-se necessário apresentar o contexto institucional e espaço-temporal onde a experiência se desenvolveu, 
assim como os seus participantes e suas etapas. O curso foi ofertado no âmbito da JOVAED que é realizada pela ABED. Criada em 1995, a ABED se estrutura como sociedade científica sem fins lucrativos e tem como objetivo apoiar o desenvolvimento da educação aberta, flexível e a distância. Mantem o periódico científico Revista Brasileira de Aprendizagem Aberta e a Distância, o Congresso Internacional ABED de Educação a Distância, com periodicidade anual e a JOVAED, evento anual, online, aberto e gratuito, que comporta atividades síncronas e assíncronas em múltiplas plataformas digitais. ${ }^{5} \mathrm{Na}$ edição de 2017 o tema foi Metodologias para Ensino, Aprendizagem e Pesquisa em Educação a Distância, com o objetivo de explorar a temática das metodologias ativas para a educação e a emergência de novas metodologias para a pesquisa em educação a distância. ${ }^{6}$ Para participar das atividades oferecidas na jornada os interessados deveriam se inscrever no site do evento, para fins de certificação da participação, e também nas atividades que desejassem participar. O estudo, portanto, consiste no relato da experiência de oferta formativa online para profissionais de educação, cujas etapas envolveram: (i) a escolha dos temas e a serem trabalhados e da plataforma digital onde o curso seria realizado; (ii) divulgação do curso por meio de e-mails e redes sociais; (iii) seleção de recursos didáticos, elaboração das atividades e preparação do ambiente; (iv) desenvolvimento das atividades componentes da propostas formativa; (v) análise descritiva dos dados obtidos através das interações ocorridas no ambiente, das respostas às atividades e questionários.

\section{[Estudo 3] Pesquisa de Campo: Análise Documental e Questionário}

Esta pesquisa teve como objetivo central investigar, no âmbito da formação inicial docente brasileira, a adoção de abordagens educativas emergentes mediadas pelas tecnologias digitais, procurando identificar sua incorporação ao currículo e à prática docente. Para tanto se procedeu em uma primeira etapa à uma análise documental (FONSECA, 2002), que teve dois objetivos: (i) mapear as principais políticas educacionais vigentes nas áreas de educação e tecnologia e formação inicial de professores. (ii) identificar a inserção da tecnologia no currículo das instituições investigadas, a saber, PUC Rio, UERJ e UFRJ, através da leitura e

\footnotetext{
${ }^{5}$ http://www.abed.org.br/site/pt/

${ }^{6}$ http://www.abed.org.br/hotsite/jovaed-2017/pt/apresentacao/
} 
análise categorial temática (BARDIN, 1977) de ementas das disciplinas que abordam a relação entre TIC e educação como temática central. Em uma segunda etapa se procedeu a elaboração e validação de um questionário que foi aplicado entre fevereiro e maio de 2018 para professores das três universidades acima mencionadas.

A etapa de análise documental, no tocante ao exame das políticas educacionais, se subdividiu nos seguintes momentos: (i) busca e seleção dos documentos a serem analisados; (ii) leitura dos documentos; (iii) classificação e categorização dos dados extraídos dos documentos. Procurou-se identificar os objetivos, principais ações, atores envolvidos e proposta de incorporação das TIC à educação. Para a análise dos currículos dos cursos de licenciatura oferecidos na modalidade presencial pelas três instituições investigadas, PUC Rio, UERJ (Campus Maracanã) e UFRJ (Todos os campi localizados na cidade do Rio de Janeiro) obedeceu-se aos seguintes critérios de busca e seleção: (i) grades curriculares e ementas de disciplinas disponíveis online no site oficial da instituição; (ii) disciplinas oferecidas pelos Departamentos de Educação ou pelos departamentos específicos dos cursos de licenciatura; (iii) disciplinas que apresentam em seu título e/ou ementa indicação de que abordam aspectos relacionados a discussão e/ou aplicação da relação educação-tecnologias. A partir da leitura das ementas emergiram dois eixos norteadores para a análise: no primeiro eixo foram alocados os conteúdos disciplinares de abordagem teórica segundo três categorias: (i) Fundamentação, (ii) Políticas e Legislação e (iii) Recursos. No segundo eixo foram alocados os conteúdos disciplinares de abordagem prática/aplicada segundo cinco categorias: (i) Instrumental, (ii) Produção, (iii) Avaliação, (iv) Curadoria e (v) Mediação.

A escolha do questionário online como instrumento de coleta de dados foi ancorada em Hill e Hill (2016) e visou atingir um número de respondentes que permitisse analisar a interface tecnologias digitais e educação na formação inicial de professores. Esta etapa foi dividida em três momentos: (i) elaboração; (ii) aplicação e (iii) análise dos dados obtidos. Na fase de elaboração, realizou-se um estudo preliminar para identificar questionários existentes com proposição similar a desta pesquisa, fundamental para a sua validação. Como referência para algumas das questões utilizadas no questionário, utilizou-se o instrumento de Espinosa (2010). O questionário foi organizado em cinco partes: (i) caracterização, onde se 
obteve o perfil dos respondentes; (ii) atuação e uso das TIC, onde os professores relataram sua experiência com as TIC nas disciplinas ministradas; (iii) mediação e avaliação, onde os professores relataram o uso que fazem das TIC para estes fins; (iv) abordagens educativas emergentes, onde os professores puderam relatar suas experiências na adoção destas abordagens e (v) percepção sobre currículo e TIC na educação, onde os professores foram questionados sobre as políticas de flexibilização curricular. Na fase de aplicação o primeiro contato foi feito por email com os coordenadores das licenciaturas para a divulgação do link do questionário (anexo), que ficou disponível na plataforma LimeSurvey. Na última fase, se procedeu à análise dos dados com o auxílio do software de análise estatística SPSS, para a análise descritiva dos dados e análise de conteúdo das respostas às perguntas abertas. O questionário foi respondido por 31 professores, sendo 2 da PUC Rio, 7 na UERJ e 22 da UFRJ.

\section{O Formato e a Estrutura da Tese}

Tendo em vista a pluralidade de objetos e questões de pesquisa suscitados pela temática supracitada, o desenho de pesquisa precisava aportar o uso de diferentes metodologias que pudessem responder questões relativas a objetos de estudo independentes mas que se correlacionam, proporcionando assim uma visão integrada e de maior amplitude sobre o tema. A tese, portanto, foi estruturada no formato multipaper contendo três estudos independentes que resguardam unidade temática e alinhamento teórico, mantendo assim uma inter-relação. A adoção de um modelo alternativo para a escrita da tese de doutorado responde a demanda do objeto de investigação, que é plural, de caráter difuso e multifacetado. O primeiro estudo é uma revisão sistemática da literatura a partir da produção acadêmica na área de Informática na Educação, onde se buscou identificar as concepções e características de modelos híbridos e adaptativos que objetivam a adaptação/personalização da aprendizagem, ou seja, o respeito ao tempo, ritmo e forma de aprendizagem individual. O segundo estudo é o relato de uma experiência de formação online destinada a professores que procurou explorar os conceitos de aprendizagem híbrida e adaptativa, assim como mobilizar mecanismos para sua operacionalização. $\mathrm{O}$ terceiro estudo pretendeu verificar, a partir da percepção de professores das licenciaturas e da análise dos currículos de seus cursos, se a formação inicial de professores está alinhada às abordagens educativas híbrida e 
adaptativa, assim como seu entrelaçamento com as políticas públicas educacionais, específicas e complementares, que visam a promoção da incorporação das tecnologias digitais à educação. Compõe também este trabalho esta introdução, onde foi apresentado o enquadramento teórico-conceitual transversal aos três estudos, assim como uma síntese conclusiva, onde se apresenta uma discussão integrada dos resultados. 


\section{Estudo 1 - Aprendizagem Híbrida e Adaptativa no Brasil: Uma Revisão Sistemática das Publicações do Simpósio Brasileiro de Informática na Educação entre 2013 e 2017}

Resumo: O objetivo deste artigo é identificar, no contexto brasileiro, as concepções e características inscritas nas experiências educativas híbridas e adaptativas que vem sendo desenvolvidas com a proposição e utilização de Ambientes Virtuais de Aprendizagem (AVA), Sistemas de Recomendação (SR), Sistemas Tutores Inteligentes (STI) e Sistemas Hipermídia Adaptativos (SHA), cujo objetivo principal é a adaptação/personalização da aprendizagem. Foi realizada uma revisão sistemática da produção acadêmica sobre o tema, com a inclusão de 63 comunicações publicadas entre 2013 e 2017 nos anais do Simpósio Brasileiro de Informática na Educação (SBIE), a fim de mapear os pressupostos pedagógicos que ancoram o processo de implementação de modelos educacionais híbridos e adaptativos, que têm como princípio respeitar o tempo, o ritmo e/ou o estilo de aprendizagem (EA) do aluno.

Palavras-Chave: Aprendizagem Híbrida; Aprendizagem Adaptativa; Ambientes Virtuais de Aprendizagem; Sistemas de Recomendação; Sistemas Tutores Inteligentes; Estilos de Aprendizagem.

\subsection{Introdução}

Quando se fala em personalização da aprendizagem na atualidade pressupõe-se a mediação de tecnologias digitais nesse processo. Porém, de quais tecnologias estamos falando? Elas realmente podem garantir a personalização da aprendizagem? De que forma e em que nível? Pierre Faure (1993) apresenta alguns fundamentos para uma educação personalizada, que é personalista e comunitária em sua concepção, identificando que a mesma é demanda/resultado de um processo que reconfigura a instituição escolar/universitária, antes um 'bloco monolítico' e agora um espaço que requer a participação, engajamento e cooperação dos antes somente usuários e agora também atores/agentes, ou seja, pais, alunos e professores. As instituições educacionais passam a reconhecer que devem prover aos alunos as condições necessárias para que os mesmos possam "excogitar as adaptações requeridas de cada um pelos progressos técnicos e exigências da civilização" (FAURE, P., 1993, p. 7) 
A escolha do percurso de aprendizagem por parte do aluno é uma forma de iniciar este processo e, nesse sentido, ambientes de aprendizagem podem se valer de algoritmos, ontologias e estratégias de recomendação variadas. A hipótese central das Ciências Cognitivas ajuda a refletir sobre os limites e potencialidades de ambientes configurados sob esta ótica, visto que para desenvolver um sistema que se adapte ao estilo de aprendizagem do aluno é necessário trabalhar com a ideia de representações mentais, e isto nos leva a alguns questionamentos: Como este aluno representa em sua mente as informações que recebe? É possível classificar estas representações e identificar estilos de aprendizagem? Se a mente humana possui representações mentais análogas às estruturas de dados dos computadores e processos de representação do conhecimento que podem ser sistematizados por algoritmos e ontologias computacionais, podemos concluir que o processo de adaptação/personalização da aprendizagem é possível, porém, em que medida?

O objetivo deste trabalho é identificar, no contexto brasileiro, as concepções e características inscritas nas experiências educativas híbridas e adaptativas que vem sendo desenvolvidas com a proposição e utilização de AVA, SR, SHA e STI, cujo objetivo principal é a personalização/adaptação da aprendizagem. A partir de uma revisão sistemática, que reúne 63 comunicações apresentadas no SBIE no período compreendido entre 2013 e 2017, estruturou-se um mapeamento dos pressupostos pedagógicos que ancoram o processo de implementação de modelos educacionais híbridos e adaptativos no Brasil, que têm como princípio respeitar o tempo, o ritmo e/ou o estilo de aprendizagem do aluno.

O artigo é composto por cinco seções: na primeira é apresentada a metodologia utilizada para a realização da revisão; na segunda é apresentada a fundamentação teórica que orientou a extração e análise dos dados obtidos através da leitura dos 63 artigos selecionados; na terceira, uma exposição de trabalhos relacionados à abordagem metodológica adotada e ao tema desta pesquisa; na quarta é feita a análise e discussão dos resultados obtidos a partir do levantamento; na quinta são apresentadas algumas considerações e possíveis desdobramentos da pesquisa.

\subsection{Metodologia}

De acordo com Vosgerau e Romanowski (2014), pode-se agrupar os estudos de revisão em dois: as revisões que mapeiam e as revisões que avaliam e sintetizam. 
As revisões de mapeamento buscam levantar indicadores que fornecem caminhos ou referências teóricas para novas pesquisas. As revisões que avaliam e sintetizam podem buscar integrar e agregar resultados de estudos quantitativos ou interpretar as evidências encontradas nos resultados de estudos qualitativos. Esta pesquisa buscou encontrar evidências da utilização das abordagens híbrida e adaptativa no contexto brasileiro, assim como as diferentes formas que assume. Além disso, alguns dados bibliométricos também foram levantados e analisados, com o intuito de verificar como a pesquisa na área está distribuída pelo país, assim como sua evolução histórica.

Segundo a Campbell Collaboration (2017), uma revisão sistemática tem como objetivo, através de procedimentos claros e previamente estabelecidos que minimizam a criação de vieses e permitem a replicação, encontrar sintetizar e avaliar os resultados das melhores pesquisas disponíveis sobre uma questão/área específica. A revisão deve incluir (i) critérios de inclusão/exclusão de artigos,(ii) uma estratégia de pesquisa explícita e (iii) uma codificação e análise sistemática dos estudos incluídos. A revisão deve partir de uma questão central de pesquisa, que identifique estudos que utilizem fontes primárias que respondem a questão mobilizadora de alguma forma.

Levando em consideração os aspectos acima mencionados acerca da natureza de uma revisão sistemática, para a realização desta pesquisa algumas etapas foram seguidas: (i) formulação das questões de pesquisa, destacando uma questão central e três específicas; (ii) delineamento do escopo da pesquisa; (iii) definição dos critérios de seleção dos trabalhos a serem analisados; (iv) seleção dos trabalhos a serem analisados, a partir de um protocolo de busca e (v) extração, análise e discussão dos dados, através da categorização e classificação dos dados obtidos.

Na primeira etapa, foram formuladas as questões norteadoras da pesquisa, sendo uma questão central e três questões específicas:

Questão Central: Como se apresentam as propostas e experiências de aprendizagem híbrida e adaptativa nas publicações da comunidade acadêmica brasileira de Informática na Educação?

Questão Específica: Quais são os pressupostos pedagógicos ensejados à estas propostas/experiências educacionais híbridas e adaptativas? 
Questão Específica 2: Como se deu a evolução histórica de publicações sobre a temática?

Questão Específica 3: Quais são as instituições que estão desenvolvendo pesquisa na área e quais parcerias interinstitucionais vem sendo estabelecidas?

$\mathrm{Na}$ segunda etapa foi feito o delineamento do escopo da pesquisa, onde optou-se pela análise de comunicações publicadas entre 2013 e 2017, nos anais do SBIE, um evento anual promovido pela Comissão Especial de Informática na Educação (CEIE) da Sociedade Brasileira de Computação (SBC) cujos objetivos são divulgar a produção científica nacional e promover a troca de experiências entre os membros da comunidade acadêmica vinculada à área de Informática Aplicada à Educação. O evento conta com 28 edições e a partir de 2012 passou a integrar o Congresso Brasileiro de Informática na Educação (CBIE), priorizando trabalhos que apresentem a concepção, o desenvolvimento e a avaliação de soluções das Tecnologias Digitais da Informação e da Comunicação para promoção da aprendizagem. ${ }^{1}$ A escolha de apenas um evento como base para recolha de dados da revisão se justifica pelo tipo de análise imersiva que se buscou alcançar, visando a sistematização das evidências através da curadoria das publicações. Com isso, buscou-se obter um panorama das pesquisas mais recentes na área, com foco nos trabalhos realizados por desenvolvedores/usuários de AVA, SR, SHA e STI, no âmbito da comunidade acadêmica brasileira de Informática na Educação.

$\mathrm{Na}$ terceira etapa foram definidos os critérios de seleção dos trabalhos, a saber: (a) trabalhos completos que apresentam propostas ou experiências com abordagem híbrida e/ou adaptativa, tais como o uso de (i) metodologias didáticas que facilitem a implementação de modelos híbridos de aprendizagem, (ii) SR, (iii) SHA, (iv) STI e (v) AVA que se pretendem adaptativos, no sentido de atender as especificidades de aprendizagem de seus usuários. Foram, portanto, selecionados estudos que abordam e documentam aspectos práticos da utilização das abordagens educativas pesquisadas; (b) trabalhos desenvolvidos e realizados por pesquisadores em âmbito nacional.

$\mathrm{Na}$ quarta etapa foram selecionados, segundo os critérios supracitados, 63 comunicações do $\mathrm{SBIE}^{2}$, em um universo de 634 comunicações publicadas no

\footnotetext{
${ }^{1}$ Anais do XXVIII Simpósio Brasileiro de Informática na Educação (SBIE 2017). Disponível em http://www.brie.org/pub/index.php/sbie/article/view/7730/5524.

${ }^{2} \mathrm{https} / / /$ drive.google.com/open?id=1hYtcMjRHwy1UFWy8k3cq0vsdRja5t5y1
} 
período compreendido entre 2013 a 2017. Para fins de seleção, foi feita a leitura de todos os títulos e resumos dos artigos publicados no período selecionado. Em alguns casos, procedeu-se à leitura da introdução e busca no texto por palavras-chave, tais como: híbrido(a), adaptativo(a), personalização, pedagógico(a), teoria, metodologia. A opção pela busca e seleção manual dos artigos, garantindo um foco qualitativo à pesquisa, se deu em virtude da especificidade do tema, que não se apresenta necessariamente de forma explícita nos trabalhos. Nesse sentido a opção por uma curadoria dos textos se apresentou como técnica mais adequada aos fins da investigação, possibilitando extrair o máximo de dados possíveis dos artigos analisados.

Na quinta etapa, procedeu-se à extração dos dados, análise e discussão dos resultados, realizada da seguinte forma: (i) identificação das instituições e parcerias institucionais que promovem experiências educacionais híbridas e adaptativas (ii) classificação das publicações por tipo de abordagem utilizada (híbrida ou adaptativa) e tipo de sistema proposto/desenvolvido (AVA, SR, STI, SHA); (iii) identificação, categorização e análise dos pressupostos pedagógicos ensejados às propostas/experiências.

\subsection{Referencial Teórico-Conceitual}

\subsubsection{Aprendizagem Híbrida}

Horn e Staker (2015), cujas premissas sobre aprendizagem híbrida influenciam o debate e a pesquisa sobe a temática no Brasil, definem que o ensino híbrido passa a se constituir em programas de educação formal, a partir de uma perspectiva de aprendizagem integrada, nos quais os alunos aprendem em parte em local físico, sob supervisão, e em parte por meio do ensino online, com algum elemento de controle dos alunos sobre o tempo, lugar, modo e/ou ritmo da aprendizagem, sendo esta uma característica fundamental para que se configure uma abordagem híbrida. Os autores identificam quatro modelos de ensino híbrido; (i) o modelo de rotação, cujas metodologias mais disseminadas são a rotação por estações e a sala de aula invertida; (ii) o modelo flex, baseado no ensino online e nas necessidades de aprendizagem individuais; (iii) o modelo à la carte, onde algumas disciplinas de cursos presenciais são ofertadas integralmente a distância e 
(iv) o modelo virtual enriquecido, onde sessões de aprendizagem presencial são complementadas por atividades realizadas a distância.

No cenário brasileiro, Valente (2014) destaca que as tecnologias promoveram mudanças substanciais, em termos de adoção e utilização de diferentes concepções teóricas, abordagens pedagógicas e processos de avaliação da aprendizagem, primeiramente na $\mathrm{EaD}$, visto que, até o final da década de 1980, havia uma separação espacial e temporal entre professor e aprendizes claramente marcada, o que é transformado com a utilização de tecnologias síncronas e assíncronas. Para o autor, a combinação do que ocorre online com o que ocorre em sala de aula presencialmente pode ser muito rica e beneficiar a aprendizagem dos alunos sob diferentes aspectos, destacando por exemplo, que a adoção do modelo de sala de aula invertida faz com que o aluno chegue à sala de aula com o conhecimento factual necessário e use o espaço presencial para desenvolver formas mais elevadas de trabalho cognitivo, como a aplicação, análise, síntese, significação e avaliação do conhecimento, que diante de uma perspectiva vygotskyana, demandam a orientação do professor e a interação com os pares (noção de par mais capaz) Porém, o autor ressalta que a adoção deste modelo depende de forte adesão dos alunos e de condições equânimes de acesso à tecnologia, em especial à internet. Moran amplia a discussão (2015) ao definir o ensino híbrido como um conjunto de saberes e valores, metodologias ativas e tecnologias híbridas, que suportam um currículo flexível, prevendo a articulação entre ensino formal e informal, com a integração de diferentes áreas e pessoas, tempos e espaços. Tori (2009) complementa, destacando que do encontro da sala de aula presencial com os ambientes virtuais de aprendizagem surgem os cursos híbridos, que levam em consideração os seguintes aspectos para sua composição: o contexto, o custo, a adequação pedagógica, os objetivos educacionais e perfis discentes. O autor também levanta a questão relativa à dicotomia distância versus presença, apontando que com as possibilidades de interação disponíveis pela via digital, "mais importa a 'sensação' de presença percebida pelo aluno que a efetiva distância física entre ele e seu professor". (Tori, 2009, p.123). Em consonância às concepções acima mencionadas, o conceito de ensino híbrido preconizado por Bacich, Neto e Trevisani (2015), em sua acepção essencial, tem a ver com a possibilidade de conjugar diferentes espaços, combinar diferentes metodologias e interagir de forma síncrona e assíncrona. Complexificando um pouco mais, o modelo pressupõe um 
equilíbrio maior no ensino/desenvolvimento de habilidades cognitivas e socioemocionais, assim como contempla aquilo que extrapola as intencionalidades pedagógicas do docente e institucionais. O modelo híbrido precisa buscar, portanto, o equilíbrio entre as dimensões individual e coletiva da aprendizagem, o que deixa claro que a adaptação/personalização da aprendizagem não é sinônimo de individualização muito menos automação da aprendizagem.

\subsubsection{Aprendizagem Adaptativa}

A proposta ensejada na concepção das plataformas adaptativas é de que as mesmas sejam capazes de aprender sobre os estudantes, podendo assim adaptar os conteúdos e/ou percursos formativos de forma personalizada, otimizando o tempo, reduzindo custos e se valendo da mediação pedagógica de professores somente quando necessário. Sistemas de recomendação, sistemas hipermídia adaptativos e sistemas tutores inteligentes são os mais utilizados para promover aprendizagem adaptativa, podendo atuar de forma independente ou integrados entre si ou ainda a um ambiente virtual de aprendizagem. Segundo Weibelzahl (2001) o princípio básico dos sistemas adaptativos (SHA e STI) é adquirir informações sobre seus usuários afim de aferir características abstratas, também chamadas de propriedades do usuário, e assim decidir como adaptar, o que impacta tanto no comportamento do usuário quanto do sistema, sendo esta última a principal diferença destes para os de sistemas de recomendação educacionais.

\subsubsection{Ambientes Virtuais de Aprendizagem (AVA) ou Learning Management Systems (LMS)}

Como a própria definição da sigla em inglês sugere, os Learning Management Systems são sistemas de gerenciamento da aprendizagem, que oferecem a infraestrutura necessária para organizar e dar suporte a este processo, seja ele realizado na modalidade a distância - e-learning - ou em um formato híbrido - b-learning. A nomenclatura "Ambiente Virtual de Aprendizagem - AVA" pode ser usada como sinônimo de LMS, mesmo identificando que, subjacente à última, está mais fortemente marcada a ideia de sistema e de aprendizagem por máquinas, realizada de forma individualizada; enquanto na primeira, o termo ambiente confere um caráter de interação e colaboração, onde a tecnologia proporciona mais um espaço de aprendizagem. 


\subsubsection{Sistemas de Recomendação (SR)}

O pressuposto básico de um sistema de recomendação é recomendar itens ao seu usuário a partir da identificação de seus interesses, preferências e características. Segundo Lichtnov et al. (2006), para além de recomendar itens em resposta às consultas do usuário, um sistema de recomendação deve permitir a previsão de possíveis interesses do usuário por um determinado item. Quando utilizados em contextos educacionais podem apresentar algumas limitações, como alertam Tang e McCalla (2004), na medida em que, além dos interesses de professores e alunos, questões como os objetivos de aprendizagem precisam ser levadas em consideração. Esta tese reforça a ideia de que requisitos pedagógicos devem ser considerados no desenvolvimentos de sistemas de recomendação que estruturam um AVA. Uma vantagem oferecida por estes sistemas consiste na facilitação do acompanhamento e avaliação do processo de aprendizagem dos alunos, numa perspectiva de personalização, na medida em que o professor têm acesso ao perfil de cada aluno - traçado pelo sistema -, seus percursos, avanços e dificuldades. Um sistema de recomendação aplicado à educação, precisa ser avaliado tanto a partir de sua dimensão técnica - capacidade de predição de itens quanto em sua dimensão pedagógica - alcance dos objetivos de aprendizagem.

Os SR podem ser classificados pelo tipo de filtragem utilizado e funcionam, segundo Drumond et al. (2006), basicamente em três etapas: (i) criação de modelos de usuário a partir de suas preferências, adquiridas por meio explícito (formulários) ou implícito (observação de comportamento); (ii) criação das representações internas dos elementos de informação por meio de técnicas, como, por exemplo, árvores de decisão e ontologias; e (iii) comparação de similaridade entre os elementos de informação e os modelos de usuário, sendo recomendados os elementos mais similares ao usuário (COSTA et al., 2013). O quadro abaixo (Quadro 1) foi organizado a partir das definições disponíveis em Cazzela et al. (2012) e Aguiar et al. (2014) e apresenta uma classificação dos sistemas de recomendação de acordo com sua técnica de filtragem, com sua respectiva definição. 


\begin{tabular}{ll}
\hline Tipos de SR & \multicolumn{1}{c}{ Definição } \\
\hline Conteúdo & $\begin{array}{l}\text { Recomenda itens ao usuário, cujo conteúdo é similar ao que o } \\
\text { usuário tenha visto ou selecionado recentemente. }\end{array}$ \\
\hline Colaborativo & $\begin{array}{l}\text { As recomendações são baseadas nas avaliações dos itens realizadas } \\
\text { por um grupo de usuários (vizinhos), cujos perfis de avaliações são } \\
\text { os mais similares aos do usuário alvo. }\end{array}$ \\
\hline Conhecimento & $\begin{array}{l}\text { Itens são recomendados com base em inferências das preferências } \\
\text { e necessidades do usuário por meio de conhecimento estruturado } \\
\text { de forma funcional. }\end{array}$ \\
\hline Utilidade & Itens são recomendados com base na sua utilidade para o usuário. \\
\hline Demográfica & $\begin{array}{l}\text { Usuários são classificados em classes com relação a perfis em } \\
\text { comum. }\end{array}$ \\
\hline Competências & $\begin{array}{l}\text { A filtragem de objetos de aprendizagem (OA), e sua posterior } \\
\text { recomendação, é feita de acordo com as competências a serem } \\
\text { construídas pelos usuários. }\end{array}$ \\
\hline Outros Contextos & $\begin{array}{l}\text { Envolve os aspectos psicológicos (inteligência emocional) do } \\
\text { usuário combinados aos aspectos caracterizadores dos itens } \\
\text { das Filtragens Baseadas em Conhecimento, Competências e }\end{array}$ \\
\hline Demográfica. \\
\hline Quadro 1: Classificação dos Sistemas de Recomendação por Tipo de Filtragem. Fonte: elaboração própria a \\
partir de Cazzela et al., 2012 e Aguiar et al. 2014.
\end{tabular}

\subsubsection{Sistemas Hipermídia Adaptativos (SHA)}

De acordo com Brusilovsky (2001) os principais componentes de um sistema hipermídia adaptativo são: (i) o modelo de usuário, responsável por representar o conhecimento do usuário; (ii) o modelo de adaptação, responsável pela seleção de estratégias pedagógicas a serem utilizadas de acordo com os dados provenientes do modelo de usuário; (iii) o modelo de domínio, responsável pelo gerenciamento do material didático-instrucional a ser apresentado ao usuário e (iv) o modelo de interface, mecanismo de interação entre o sistema adaptativo e seus usuários.

\subsubsection{Sistemas Tutores Inteligentes (STI)}

Com o advento do conceito de Inteligência Artificial (IA), ainda na década de 50 do século $\mathrm{XX}$, são desenvolvidos os primeiros Sistemas de Instrução Assistida pelo Computador, lineares e ramificados, majoritariamente inspirados pelas teorias comportamentalistas, que se constituíram como o embrião dos STI atuais, que tem como principais características o funcionamento autônomo, flexibilidade e adaptatividade. Esta última característica, a adaptatividade, passa a ser incorporada no final da década de 60 do século XX, com o desenvolvimento dos sistemas gerativos ou adaptativos consubstanciados por uma perspectiva 
educacional que leva em consideração o nível de conhecimento do aluno na proposição de atividades de aprendizagem. Com o surgimento das teorias cognitivistas, a perspectiva comportamentalista passa a ser questionada e os problemas dos sistemas gerativos, precisamente sua dificuldade em concatenar os processos informáticos do sistema e os processos cognitivos de seus usuários/alunos, servem de mote para o desenvolvimento dos primeiros STI nos anos 80 da década passada, com o intuito de identificar a melhor forma de representar o conhecimento em sistemas inteligentes. (GAVIDIA e ANDRADE, 2003). O termo Sistemas Tutores Inteligentes foi cunhado por Sleeman (1984) ao realizar uma revisão do estado da arte para identificar as diferenças destes para os seus predecessores. os Sistemas de Instrução Assistida, apontando o 'aprender fazendo' como pressuposto educativo implícito aos STI. Wenger (1987) define os STI como sistemas instrucionais baseados em computador compostos por modelos instrucionais que indicam o conteúdo a ser ensinado assim como as estratégias de ensino serem adotadas. A configuração destes sistemas é constituída por quadro modelos: (i) o conteúdo a ser ensinado constitui o modelo de domínio;(ii) as estratégias de ensino adotadas constituem o modelo pedagógico, que, para atender ao pressuposto da personalização da aprendizagem, se baseiam no (iii) modelo de aluno, onde são armazenadas suas características; a interação entre tutor-aluno é intermediada pelo (iv) modelo de interface. Seu diferencial para os SHA é a utilização de diferentes técnicas de inteligência artificial na composição dos sistemas e a presença de um modelo pedagógico (Gavidia e Andrade, 2003).

\subsection{Trabalhos Relacionados}

Aguiar et al. (2014a) produziram um mapeamento sistemático sobre sistemas de recomendação educacionais (SRE) no Brasil a partir de trabalhos publicados em periódicos e anais de eventos da área de Informática na Educação, destacando as técnicas de recomendações mais utilizadas e os recursos mais recomendados. Tendo como base este mapeamento, estes mesmos autores (Aguiar et al., 2015) realizaram uma revisão sistemática da literatura para analisar especificamente a questão da avaliação de SRE no Brasil, destacando a falta de dados de referência e de padronização dos procedimentos de avaliação. Em um mapeamento sistemático sobre estilos cognitivos e estilos de aprendizagem em informática na educação, 
Aguiar et al. (2014b), identificam as diferenças encontradas em termos de categorização e os modelos teóricos utilizados nos trabalhos analisados.

Machado et al. (2015) produziram uma revisão sistemática acerca de abordagens ubíquas para recomendação educacional, com o intuito de investigar se elas estariam se tornando adaptativas.

Já Henrique et al. (2015) realizaram uma revisão sistemática que procurou verificar o uso de teorias de aprendizagem no desenvolvimento de softwares educacionais.

Araújo, Silva e Aranha (2016) realizaram uma revisão sistemática para identificar como os jogos adaptativos estão sendo aplicados na educação e quais abordagens e técnicas estão sendo utilizadas para desenvolvê-los.

Nascimento et al. (2017) produziram uma revisão sistemática da literatura com o objetivo de avaliar o estado da arte sobre a recomendação de objetos de aprendizagem baseadas em estilos de aprendizagem.

Ferreira, Vasconcelos e França (2017), através de um mapeamento sistemático da literatura, buscou identificar o estado atual da pesquisa sobre sistemas de recomendação educacional no Brasil, apontando suas principais características e modelos de avaliação.

Machado, Souza e Barrère (2017) apresentam uma revisão dos trabalhos que se utilizam de computação evolucionária para selecionar uma sequência curricular adaptativa que objetiva a disponibilização um ensino individualizado.

Schiel e Gasparini (2017), com um mapeamento sistemático da literatura, visaram identificar os principais modelos de ensino híbrido existentes, como estes vem sendo utilizados na educação pública e em quais níveis de ensino são abordados,

Os mapeamentos e revisões sistemáticas da literatura supracitados, exceto Henrique et al. (2015) e Schiel e Gasparini (2017), elencam as características técnicas necessárias a sistemas de recomendação educacionais e sistemas adaptativos de aprendizagem, mas não indicam ou evidenciam os pressupostos pedagógicos que os suportam. A revisão realizada por Henrique et al. (2015) se aproxima desta pesquisa, na medida em que também busca a elicitação dos pressupostos pedagógicos que consubstanciam os ambientes e sistemas informáticos de aprendizagem, porém se afasta na medida em que não contempla a dimensão da adaptação/personalização da aprendizagem, compreendida na 
concepção e operacionalização das aprendizagens híbrida e adaptativa. Schiel e Gasparini (2017) fazem uma pesquisa de tipo mapeamento e se concentram na temática da aprendizagem híbrida. A revisão proposta neste artigo pretende identificar os pressupostos pedagógicos que consubstanciam a construção de ambientes e sistemas adaptativos de aprendizagem e a estruturação de práticas híbridas de aprendizagem.

\subsection{Análise e Discussão dos Resultados}

$\mathrm{Na}$ seleção final das publicações que compõem esta revisão, foram incluídos artigos que apresentam experiências de ensino híbrido com a utilização de metodologias ativas e experiências de ensino adaptativo com a utilização de SR, SHA, STI e AVA que tem como objetivo identificar e/ou atender as características/necessidades individuais de aprendizagem dos usuários. Os gráficos a seguir (Figuras 1, 2, 3 e 4) apresentam a distribuição dos trabalhos analisados por região, parceria inter-regional, afiliação institucional e área de atuação dos autores, respectivamente. A maior parte dos trabalhos, 29, foram desenvolvidos na região sudeste e apenas cinco são fruto de parcerias inter-regionais. Há uma tendência de crescimento de parcerias interinstitucionais, que somam 28 publicações sendo 10 somente em 2017, porém as mesmas se dão, majoritariamente, dentro de uma mesma região. O domínio da produção sobre o tema está na área da computação/informática, 52 artigos têm pelos menos um autor atuante nesta área e somente a partir de 2016 surgem publicações sem autores atuantes nesta área.

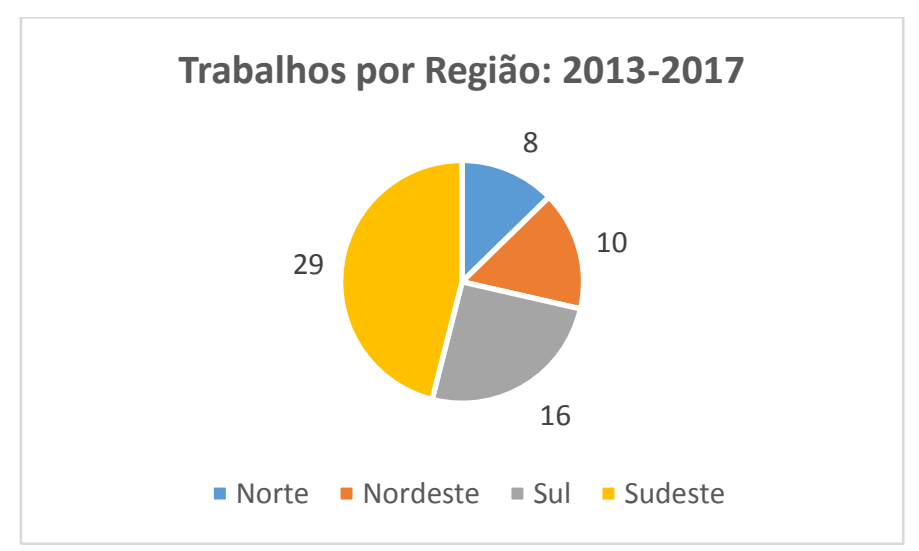

Figura 1: Distribuição dos trabalhos analisados por região: SBIE 3013-2017. 


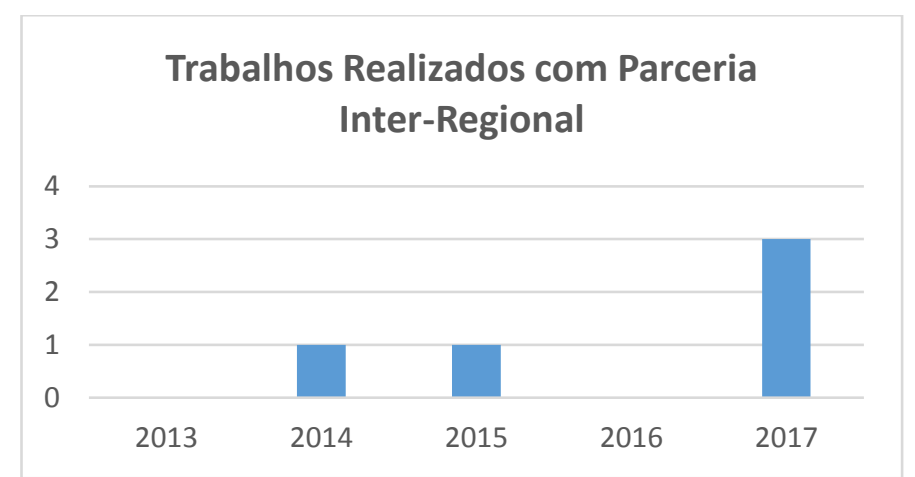

Figura 2: Distribuição dos trabalhos analisados com parceria inter-regional: SBIE 2013-2017.

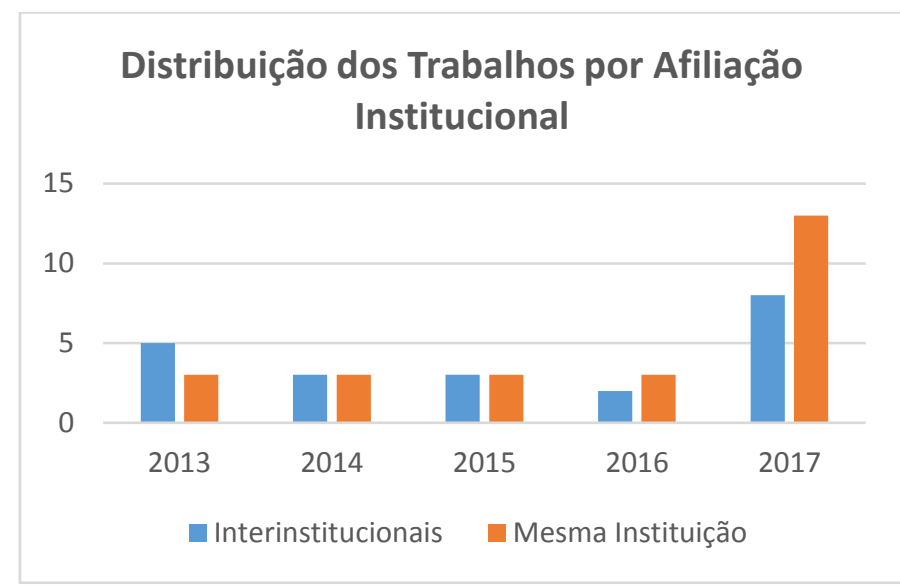

Figura 3: Distribuição dos trabalhos analisados por afiliação institucional: SBIE 2013-2017.

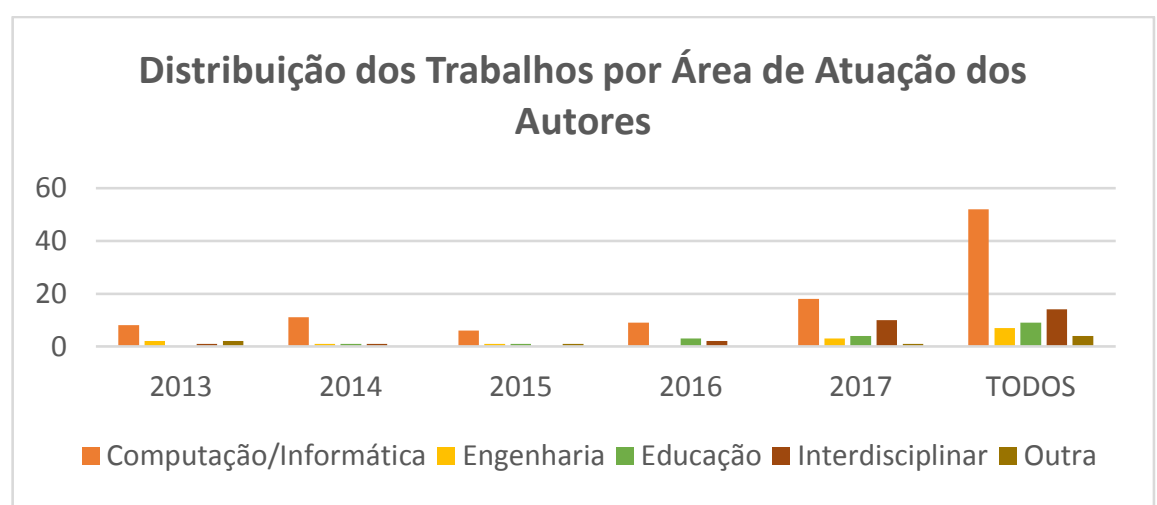

Figura 4: Distribuição dos trabalhos por área de atuação dos autores: SBIE 2013-2017.

As figuras 5 e 6 apresentam as publicações analisadas pela abordagem educativa adotada e e tipo de sistema informático desenvolvido/utilizado. A aprendizagem adaptativa é predominante, contando com 58 trabalhos. Os cinco trabalhos que lançam mão de uma abordagem híbrida adotam os seguintes sistemas informáticos para compor seus momentos online: dois utilizaram ambientes de correção automática de códigos; Facebook Groups; Moodle (com uso de Learning Analytics para aferir a contribuição da utilização do ambiente virtual em colaboração às atividades presenciais); Repositórios (disponibilizando um artigo e 
dois vídeos disponíveis em plataformas digitais). Entre os que adotam uma abordagem adaptativa se destacam os usos de AVA (23) e SR (20).

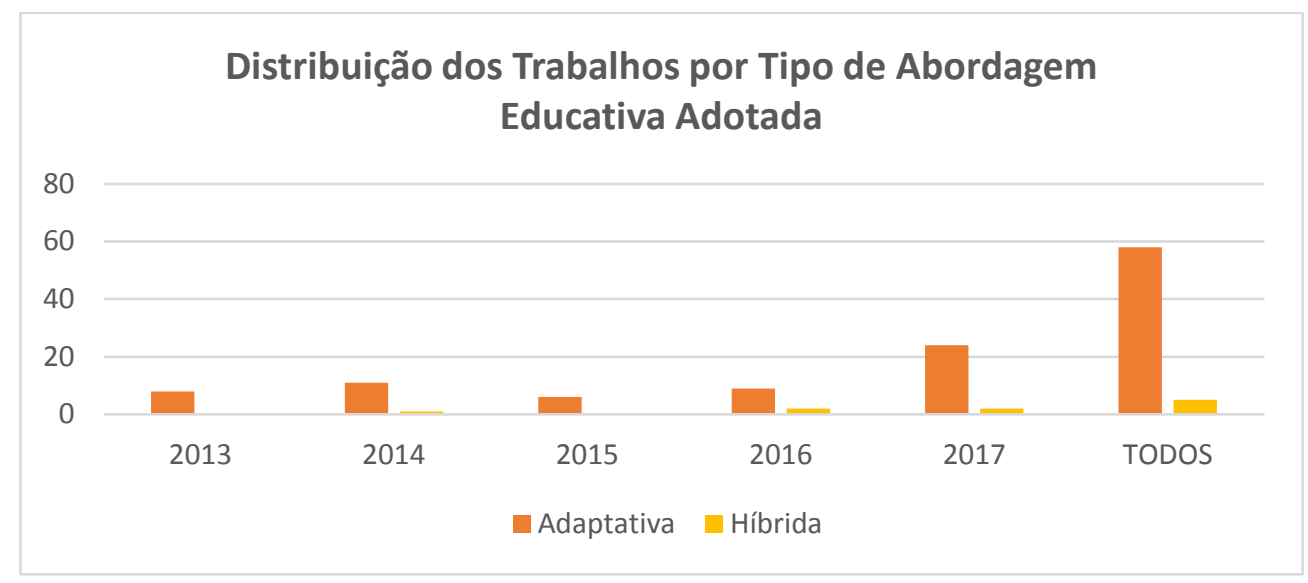

Figura 9: Distribuição dos trabalhos por tipo de abordagem educativa adotada: SBIE 2013-2017.

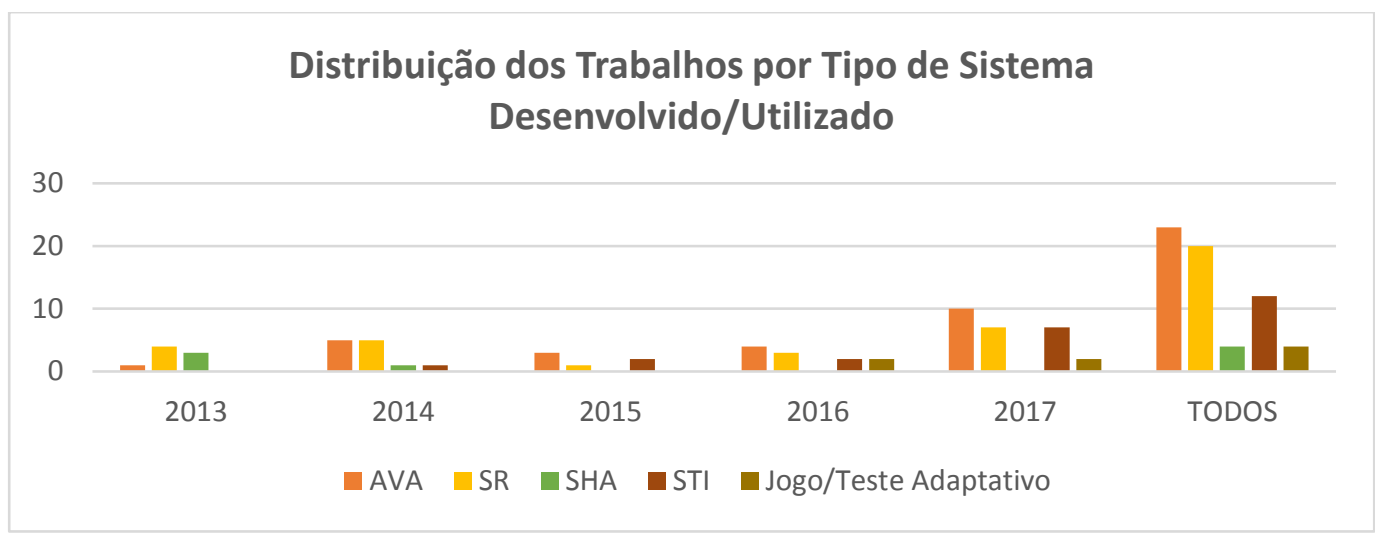

Figura 6: Distribuição dos trabalhos por tipo de sistema desenvolvido/utilizado na proposta/experiência: SBIE 2013-2017.

A presença da teoria de Estilos de Aprendizagem, em especial do modelo Felder-Silverman (1988), como pressuposto pedagógico central ou subjacente em 31 dos 63 trabalhos analisados (sendo 23 destes propostos/executados no formato de AVA ou SR, o que representa mais da metade dos trabalhos que adotaram estes sistemas), exige uma análise acerca do conceito e sua aplicabilidade aos sistemas adaptativos ou como elemento norteador na adoção de uma abordagem híbrida. A partir da identificação do EA, que demonstra como o aprendiz lida com as informações que recebe, seria possível propor um percurso de aprendizagem adequado ao seu perfil, suas preferências, à forma como organiza e representa as informações, assim como as mobiliza na construção do conhecimento. Ferreira et al. (2017) apontam que as diferentes teorias de EA foram elaboradas com base em pressupostos de uma educação tradicional e presencial, por isso é necessário 
compreender os conceitos implicados, sua dinâmica de funcionamento e identificar os comportamentos dos atores envolvidos em um ambiente de educação tradicional/presencial para transpor estes componentes em ações realizadas em ambientes virtuais de aprendizagem. Ao detectar o EA e recomendar conteúdos e percursos de aprendizagem no formato que melhor se encaixa ao estilo do aprendente, corre-se o risco de ir na contramão de um dos princípios básicos da educação, o de sua integralidade. Adequar a oferta de conteúdo a um formato específico pode limitar as possibilidades de aprendizagem e o desenvolvimento de habilidades, uma crítica já existente ao Sistemas de Instrução Assistida pelo Computador que culminou no desenvolvimento dos STI. Parte dos estudos analisados que usam os EA como pressuposto pedagógico reconhece sua natureza probabilística e mutável ao longo do percurso de aprendizagem, entendendo que a forma de aprender do aluno é variável e que a oferta diversificada de formatos de apresentação de conteúdos colabora para o desenvolvimento de habilidades relacionadas a EA que não são detectados em avaliações diagnósticas iniciais. Este reconhecimento se apresenta como uma reflexão/ponderação acerca das críticas que estas teorias vem recebendo, tais como a falta de evidências advindas de estudos experimentais que validem a aplicação dos EA à educação, destacada por Pashler et al. (2009) e a recente e contundente crítica de Kirshner (2017), onde defende que se há uma preferência por um determinado estilo, esta significa fraqueza em relação aos demais - que devem então ser desenvolvidos - e, portanto, deve ser eliminada e não respeitada. O número expressivo de trabalhos que fazem uso dos EA como arcabouço teórico principal se explica tanto pela aderência técnica, na medida em que podem inferir a maneira como indivíduos preferem receber e processar informações, funcionando assim adequadamente à construção de sistemas adaptativos, quanto por sua função orientadora da prática docente, na medida em que oferece elementos norteadores para a gestão da aprendizagem. A pesquisa conduzida por Newton e Miah (2017) indica que mesmo sem evidências da eficácia do uso dos EA, os professores respondentes afirmam que pretendem continuar fazendo uso dos EA no planejamento, organização e execução de atividades docentes. É possível que essa relação percepção-atitude esteja relacionada ao fato dos EA se constituírem como parâmetros mais concretos de orientação da prática docente e de avaliação do processo de aprendizagem, o que sustentaria a continuidade de seu uso. 
O quadro 2 permite visualizar os demais pressupostos pedagógicos encontrados nas publicações analisadas, categorizados em seis dimensões (i) Teorias Pedagógicas; (ii) Metodologias Didáticas; (iii) Avaliação; (iv) Mediação Docente; (v) Aspectos Atitudinais e Comportamentais Estimulados no Aluno/Usuário e (vi) Objetivos Pedagógicos. Estes dados oferecem subsídios para discutir a relação entre as opções técnicas e pedagógicas adotadas na constituição de modelos híbridos e adaptativos de aprendizagem.

\begin{tabular}{|c|c|}
\hline Pressupostos Pedagógicos & Utilizados nas Publicações \\
\hline Teorias de Aprendizagem & $\begin{array}{l}\text { - } \quad \text { Aprendizagem Experiencial (Kolb); } \\
\text { - } \quad \text { Aprendizagem Significativa (Ausubel); } \\
\text { - } \quad \text { Cognitivismo; } \\
\text { - } \quad \text { Comportamentalismo; } \\
\text { - } \quad \text { Construtivismo (Piaget); } \\
\text { - } \quad \text { Estilos de Aprendizagem (Kolb; Felder-Silverman); } \\
\text { - } \quad \text { Sócio-interacionismo (Vygotsky); } \\
\text { - } \quad \text { Taxonomia de Bloom; } \\
\text { - Teoria Cognitiva da Aprendizagem Multimídia; } \\
\text { - } \quad \text { Teoria das Inteligências Múltiplas (Gardner); } \\
\text { - Teoria PASS; } \\
\text { - Teria da Carga Cognitiva; } \\
\quad \text { Teria da Estrutura do Intelecto. }\end{array}$ \\
\hline Metodologias Didáticas & 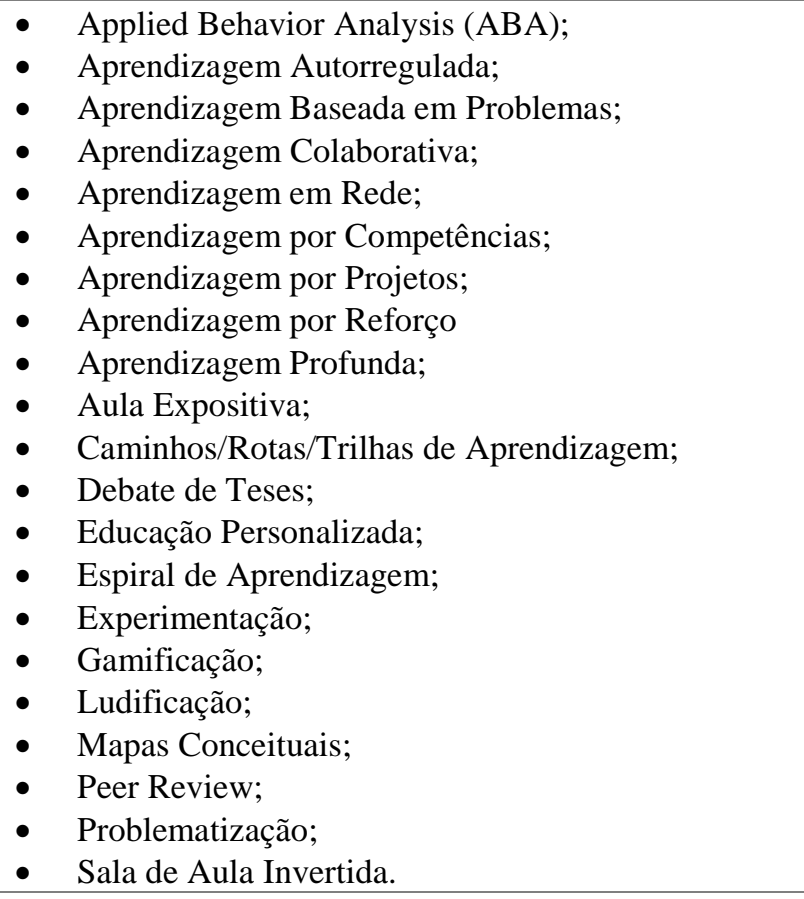 \\
\hline Avaliação & $\begin{array}{l}\text { - } \quad \text { Avaliação Contínua; } \\
\text { - } \quad \text { Avaliação de Desempenho; } \\
\text { - } \quad \text { Avaliação Diagnóstica; } \\
\text { - } \quad \text { Cognitive Assessment System (CAS); } \\
\text { - } \quad \text { Learning Analytics; } \\
\text { - } \quad \text { Nível de Aquisição de Conhecimentos; } \\
\text { - } \quad \text { Orientadora da Aprendizagem; } \\
\text { - } \quad \text { Predição de Zona de Aprendizagem; }\end{array}$ \\
\hline
\end{tabular}




\begin{tabular}{|c|c|}
\hline & $\begin{array}{l}\text { - } \quad \text { Semiótica; } \\
\text { - } \quad \text { Teoria da Resposta ao Item (TRI); } \\
\text { - } \quad \text { Teste Adaptativo Informatizado (TAI). }\end{array}$ \\
\hline Mediação Docente & 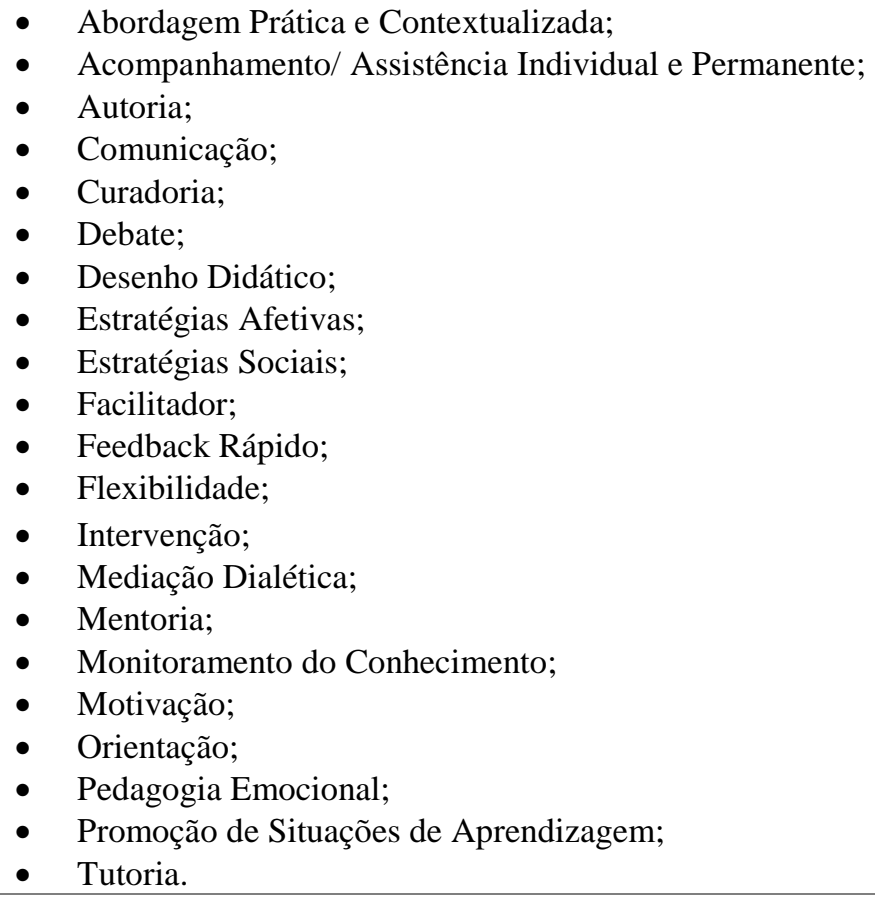 \\
\hline $\begin{array}{l}\text { Aspectos Atitudinais e } \\
\text { Comportamentais Estimulados no } \\
\text { Aluno/Usuário }\end{array}$ & 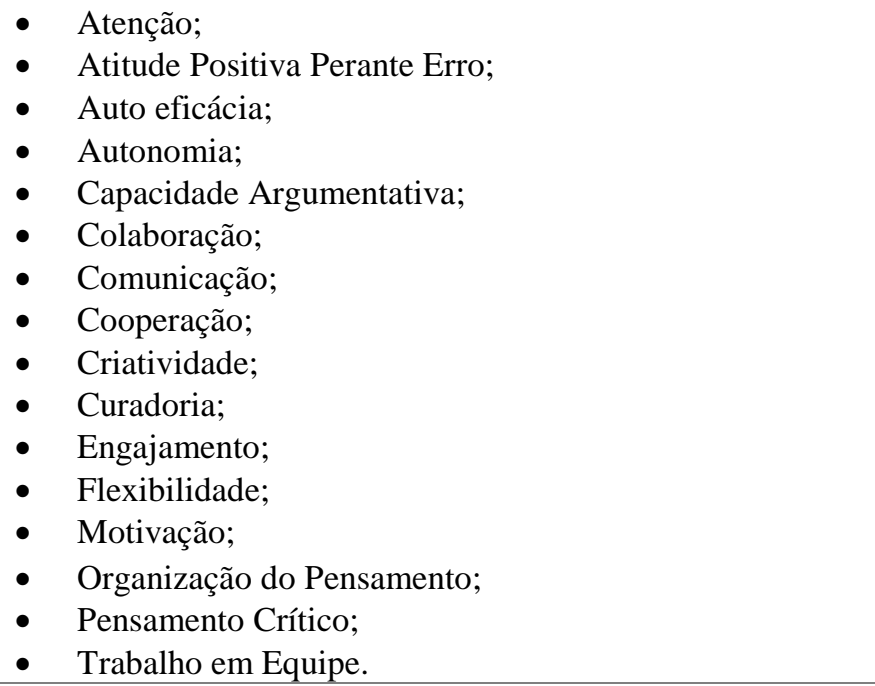 \\
\hline Objetivos Pedagógicos & $\begin{array}{ll}\text { - } & \text { Adaptação; } \\
\text { - } & \text { Combate à Evasão e Repetência; } \\
\text { - } & \text { Customização; } \\
\text { - } & \text { Desenvolvimento de Habilidades e Competências; } \\
\text { - } & \text { Estímulo Motivacional; } \\
\text { - } & \text { Flexibilização Curricular; } \\
\text { - } & \text { Melhoração; } \\
\text { - } & \text { Personalização; } \\
\text { - } & \text { Superação das Dificuldades de Aprendizagem; } \\
\text { - } & \text { Transdisciplinaridade. }\end{array}$ \\
\hline
\end{tabular}

Quadro 2: Pressupostos pedagógicos das propostas/experiências de aprendizagem híbrida e adaptativa. Fonte: autoria própria, a partir da análise das publicações do SBIE 2013-2017.

Segundo Nevado (2007), as arquiteturas pedagógicas conferem à aprendizagem um "suporte estruturante", entrelaçando aparato técnico e proposta 
pedagógica, a partir de um viés ecossistêmico. Essa combinação deve incluir, e promover a interlocução, dos seguintes elementos: abordagem pedagógica, software, internet, Educação a Distância, concepção de interconexão em tempos e espaços múltiplos. Entendemos que a proposta de adaptação de um ambiente ou sistema de aprendizagem deve estar diretamente relacionada a dois aspectos de forma simultânea: (a) aspectos técnicos, no tocante à sua arquitetura pedagógica, ao(s) tipo(s) de recomendação e recursos tecnológicos a serem utilizados, e (b) aspectos pedagógicos, que se constituem nos pressupostos pedagógicos adotados, que se manifestam na forma de teorias de aprendizagem, metodologias didáticas, estratégias de avaliação e mediação e objetivos educacionais.

Para além da Teoria dos Estilos de Aprendizagem, se destacam como pressuposto pedagógico adotado nos trabalhos analisados, a teoria sócio histórica ou sócio interacionismo de Lev Vygostsky (2005 e 2010) - que compreende a aprendizagem como uma atividade social, baseada no diálogo, onde os artefatos tecnológicos se constituem como signos estruturantes da ação humana, atuando tanto como produtos quanto como produtores de uma cultura - e o construtivismo de Jean Piaget (1975) - segundo o qual a aprendizagem se dá a partir de dois movimentos: a assimilação, que é a incorporação de objetos do mundo exterior a esquemas mentais preexistentes e a acomodação, que se refere às modificações dos sistemas de assimilação influenciadas pelo mundo externo - como fundamentação teórica dos ambientes e sistemas propostos/utilizados, confirmando a mudança paradigmática ocorrida no final da década de 60 do século XX, onde as teorias comportamentalistas deram lugar às teorias cognitivistas, em especial o construtivismo, como base teórica para o desenvolvimento de sistemas adaptativos.

Personalização, adaptação, flexibilização, autonomia e colaboração, que apareceram com mais frequência entre os trabalhos analisados, são os pressupostos pedagógicos que surgem tanto como objetivos educacionais, aspectos atitudinais e comportamentais a serem estimulados e características da mediação docente. A preocupação didático-metodológica aparece em alguns trabalhos sob um formato diferente de uma indicação de um método/modelo de ensino específico ou um conjunto de estratégias pedagógicas específicas. Em alguns casos, a preocupação com o ensinar, com a didática em sua essência, como a composição de situações e sequências didáticas, é a base da constituição de ambientes virtuais de aprendizagem, sistemas de recomendação, hipermídia adaptativos e tutores 
inteligentes. Ao perceber dificuldades dos alunos na compreensão de conteúdos, baixo rendimento em disciplinas e problemas de desempenho em cursos, pesquisadores/professores buscam soluções tecnológicas que auxiliem na resolução destes problemas, abrindo espaço par realocar a avaliação como um componente potencialmente (re)estruturante do processo de aprendizagem. Muito ao contrário de um processo que busca a substituição do professor por genéricos digitais, os trabalhos analisados apontam na direção da utilização de inteligência artificial, aprendizagem de máquinas, mineração de dados e learning analytics como ferramentas que agregam valor e otimizam o trabalho imprescindível da mediação pedagógica realizada pelo professor ou tutor, que, com a utilização de ferramentas de autoria, cada vez mais assume uma postura de designer instrucional e curador de informações. Desta forma a intervenção docente junto aos alunos acontece prioritariamente sob a forma de orientação e supervisão, com o suporte dos dados provenientes dos sistemas utilizados. A construção de módulos pedagógicos, onde estão inseridas estratégias pedagógicas - em geral não discriminadas nos trabalhos analisados - para a adaptação/personalização do processo de aprendizagem demonstra que, mesmo sem estar consubstanciado por alguma teoria de aprendizagem, os ambientes e sistemas analisados são desenvolvidos com base em pressupostos pedagógicos, mesmo que não haja a explicitação e discussão do conjunto de estratégias pedagógicas que compõe os respectivos módulos pedagógicos. Uma ausência identificada nos trabalhos que se valem da avaliação de desempenho como pressuposto pedagógico, geralmente baseada em objetivos, rubricas e/ou competências, reside no fato de não apresentarem discussão/fundamentação teórica sobre o papel da avaliação no processo de aprendizagem, limitando-se a indicar seu uso de forma diagnóstica e/ou classificatória. Em suma, sistemas e ambientes de aprendizagem que são desenvolvidos sob o pressuposto inscrito nas abordagens híbrida e adaptativa, de respeito ao tempo, ritmo e forma de aprendizagem do aluno, não podem ser considerados apenas um software ou uma nova pedagogia, mas um híbrido, uma abordagem constituída na interface técnico-pedagógica.

\subsection{Considerações Finais}

A partir do que a literatura sobre o tema nos informa e dos resultados que esta pesquisa apresenta, é possível afirmar que a adoção de modelos de aprendizagem 
híbridos e adaptativos, que contemplam a utilização de sistemas computacionais em sua abordagem, permitem maior possibilidade de escolha de recursos e estratégias, controle e acompanhamento por parte de alunos, professores e gestores, mas que é limitada por uma característica inerente a um sistema de processamento de dados, que reconhece e pode contribuir apenas com a aprendizagem representacional. E, como nos alerta Faure (1993), o ensino personalizado, em sua acepção educativa, deve se entranhar pedagogicamente em níveis micro: em algumas estratégias pedagógicas, em algumas disciplinas, em todos os níveis de ensino e especialmente na formação inicial de professores, até que seja possível mobilizar mudanças mais profundas e estruturais.

A escolha de técnicas de recomendação e adaptação que suportam modelos híbridos e adaptativos precisam estar alinhadas a pressupostos pedagógicos, que por sua vez devem contemplar teorias de aprendizagem, metodologias didáticas, objetivos de aprendizagem e critérios de avaliação claros, exigindo assim um trabalho colaborativo entre profissionais da educação e da informática, invertendo desta forma o modus operandi atual, onde as propostas pedagógicas tem que se adaptar aos sistemas/ambientes, enquanto os sistemas/ambientes educacionais deveriam ser pensados e desenvolvidos a partir de pressupostos pedagógicos.

Cabe lembrar que aprendizagem híbrida e adaptativa não é sinônimo de individualização total do processo, mesmo que coloquem o aluno no centro do processo e com postura ativa, ao contrário, permite potencializar tanto sua dimensão individual quanto coletiva; trata-se, portanto, de uma aprendizagem que respeita o ritmo de desenvolvimento de cada aluno. Atender aos interesses e necessidades individuais do aprendente, respeitando a diversidade social e cultural, é um pressuposto básico de diversas teorias de aprendizagem assim como de políticas públicas na área de educação. O desafio é alinhar o discurso à prática, materializar as proposições políticas através de estratégias de implementação e acompanhamento efetivas, tais como a reestruturação curricular e ampliação da oferta educativa em diferentes níveis e formatos, buscando uma igualdade de oportunidades, ambos movimentos a serem orientados pela paradigma da equidade. A demanda é, portanto, por uma reestruturação profunda de todo o sistema educacional que ainda está erguido sob o paradigma iluminista da igualdade, nesse sentido, as tecnologias digitais podem tanto reforçar as desigualdades existentes quanto tem o potencial de ajudar a rompê-las, visto que o processo de 
democratização do acesso à escola e à universidade foi pautado no pressuposto da universalização, o que não foi replicado a contento em termos de formação docente e reorganização da infraestrutura escolar, abrindo espaço para o crescimento da educação a distância, no intuito de suprir tais necessidades. O desafio que se impõe é que a adoção de abordagens educativas mediadas pelas tecnologias digitais cumpram sua função emancipatória, não aprofundem as desigualdades nem contribuam para a ampliação da precarização na educação.

Um dos desdobramentos desta pesquisa consistirá na ampliação deste estudo, com vistas a aprofundar a discussão sobre a incorporação de pressupostos pedagógicos à sistemas e ambientes que consubstanciam a adoção de abordagens educativas híbridas e adaptativas. 


\section{Estudo 2 - Abordagens Educativas Emergentes: Explorando Conceitos}

Resumo: Face à transformação iminente da sociedade pela via digital, e por consequência da escola e da universidade, há uma crescente demanda por capacitações que permitam aos professores repensar e reorganizar sua prática docente. Este estudo descritivo apresenta o relato de uma experiência de oferta formativa online para profissionais de educação, cujo objetivo era apresentar, discutir e explorar os conceitos de Aprendizagem Híbrida e Aprendizagem Adaptativa. Nesse relato são abordados aspectos relativos à elaboração de uma formação online, a organização do ambiente virtual de aprendizagem, e seus resultados. O referencial teórico com o qual a pesquisa opera foi construído a partir de três conceitos chave: engajamento digital, produção de presença e mediação. Os resultados obtidos apontam para um interesse crescente pelos temas abordados e suas implicações didático-metodológicas, visto que a maioria dos cursistas pouco conhecia estas abordagens educativas antes da realização do curso.

Palavras-chave: Aprendizagem Híbrida; Aprendizagem Adaptativa; Engajamento Digital; Produção de Presença; Mediação; Formação de Professores.

\subsection{Introdução}

O minicurso "Aprendizagem Híbrida e Adaptativa: Teoria e Prática”, surgiu da necessidade de pôr em diálogo a teoria, com as leituras realizadas sobre essas abordagens educativas emergentes, e a prática, com a sua respectiva aplicação no formato de curso voltado para profissionais de educação. Desta forma se delineou um contributo no formato de produto, um curso aberto e gratuito para profissionais da educação. A Jornada Virtual ABED de Educação a Distância (JOVAED), promovida pela Associação Brasileira de Educação a Distância (ABED), por seu alcance nacional e ampla divulgação, foi escolhida como espaço para realização da formação e, para tanto, se procedeu ao preenchimento do formulário de proposta de minicurso e, após o aceite, à organização do ambiente em que se desenvolveriam as atividades. Na sequência, realizou-se a divulgação através de meios digitais como e-mails e redes sociais.

Na primeira seção do trabalho é apresentada a metodologia empregada neste estudo descritivo, com uma breve descrição da JOVAED e da ABED, de 
modo a apresentar o contexto em que o curso foi inserido; na segunda seção é apresentado o referencial teórico com os três conceitos com os quais a pesquisa opera: engajamento digital, produção de presença e mediação; na terceira seção é apresentada a descrição da experiência e a análise e discussão de seus resultados; na quarta seção são apresentadas algumas considerações finais.

\subsection{Metodologia}

A motivação de Silva (2003) em "criar e professorar um curso [online] para nele exercitar a superação de um problema que emperrou a aprendizagem presencial e agora prejudica igualmente a aprendizagem online: a pedagogia da transmissão" (Silva, 2003, p. 53), foi a mesma que conduziu este estudo a ser estruturado na forma de um relato de experiência. Se a aprendizagem híbrida e adaptativa, tema do minicurso, demanda dos professores uma postura de curadores e não mais de guardiões e transmissores, estes precisam adquirir habilidades e desenvolver estratégias para exercer a docência online, nada melhor que propor um curso neste formato para explorar, não só os conceitos-objetos de estudo, como também os desafios e potencialidades da mediação online, assim como as possibilidades de sua interlocução com a mediação presencial.

Com a adoção dessa opção metodológica. torna-se necessário apresentar o contexto institucional e espaço-temporal onde a experiência se desenvolveu, assim como os seus participantes e suas etapas. O curso foi ofertado no âmbito da JOVAED que é realizada pela ABED. Criada em 1995, a ABED se estrutura como sociedade científica sem fins lucrativos e tem como objetivo apoiar o desenvolvimento da educação aberta, flexível e a distância. Mantem o periódico científico Revista Brasileira de Aprendizagem Aberta e a Distância, o Congresso Internacional ABED de Educação a Distância, com periodicidade anual e a JOVAED, evento anual, online, aberto e gratuito, que comporta atividades síncronas e assíncronas em múltiplas plataformas digitais. Na edição de 2017 o tema foi Metodologias para Ensino, Aprendizagem e Pesquisa em Educação a Distância, com o objetivo de explorar a temática das metodologias ativas para a educação e a emergência de novas metodologias para a pesquisa em educação a distância. Para participar das atividades oferecidas na jornada os interessados deveriam se inscrever no site do evento, para fins de certificação da participação, e também nas atividades que desejassem participar. O estudo, portanto, consiste no 
relato da experiência de oferta formativa online para profissionais de educação, cujas etapas envolveram: (i) a escolha dos temas e a serem trabalhados e da plataforma digital onde o curso seria realizado; (ii) divulgação do curso por meio de e-mails e redes sociais; (iii) seleção de recursos didáticos, elaboração das atividades e preparação do ambiente; (iv) desenvolvimento das atividades componentes da propostas formativa; (v) análise descritiva dos dados obtidos através das interações ocorridas no ambiente, das respostas às atividades e questionários.

\subsection{Engajamento Digital, Produção de Presença e Mediação em Modelos Híbridos e Adaptativos}

Um perfil de aprendente engajado digitalmente é proposto por Anderson (2007), para quem este transita entre os mundos online e físico, compreende que existem diferentes caminhos e ferramentas a serviço de sua aprendizagem, passando a reconhecer indicadores de qualidade do processo. A enorme quantidade de conteúdos disponíveis somada à ubiquidade da comunicação e seus mais variados agentes se transformam em uma equação cujo resultado é um ambiente profícuo à emergência de uma cultura participatória e de expansão dos contextos educativos.

Gourlay (2017) remonta a perspectiva supracitada e elabora o constructo engajamento digital que, (i) é resultante da reconfiguração de tempo e espaço, (ii) pressupõe a superação da visão binária entre digital e analógica, (iii) é dialógico e social; (iv) é configurado como uma prática sócio-material, que demanda uma universidade [escola] digital concebida em sua relação com o material, ou seja, que precisa ser re-corporificada, na medida em que o “(...) o digital tornou-se entrelaçado a práticas preexistentes, em vez de suplantá-las inteiramente, como é frequentemente afirmado na literatura acadêmica e nas formulações de políticas" (GOURLAY, 2017, p.417) e mobiliza maior complexidade e interação, na medida em que o lócus de ação educativa é distribuído.

A opção por discutir o conceito de presença a partir de Gumbrecht (2010) surge da observância de uma articulação intrínseca entre os pressupostos de uma aprendizagem híbrida e adaptativa, na qual a ideia de engajamento digital é subjacente, e a hipótese central das Ciências Cognitivas, pois para se pensar um sistema informático que se adapte ao estilo de aprendizagem, representado pela equação tempo+ritmo+forma de aprendizagem do aluno, é necessário trabalhar com 
a ideia de representações mentais, consequentemente considerando a aprendizagem apenas em sua dimensão de processamento de informação, que por sua vez está vinculada à tradição hermenêutica e cartesiana, que colocam em segundo plano a dimensão estética, a apreensão do mundo pelos sentidos. A discussão sobre produção de presença, portanto, é justificada por sua capacidade de ancorar teoricamente a identificação de limites e possibilidades na compreensão do mundo mediada pelas tecnologias e sua perspectiva representacional. A aposta de Gumbrecht (2010) na constituição de uma alternativa não hermenêutica para se pensar e compreender o mundo é pautada na materialidade, corporeidade e substancialidade humana. Em síntese, o que se pretende é estabelecer uma "relação com as coisas do mundo que possa oscilar entre efeitos de presença e efeitos de sentido" (GUMBRECHT, 2010, p.15). Assumindo produção de presença como "eventos e processos nos quais se inicia ou se intensifica o impacto dos objetos 'presentes' sobre corpos humanos" (GUMBRECHT, 2010, p.13), temos uma aproximação ao constructo de mente estendida (CLARK, 2003), segundo o qual somos naturalmente ciborgues, na medida em que nos relacionamos com o mundo através da linguagem - mesmo pressuposto do conceito de engajamento digital -, criando uma conexão entre mente e mundo sempre mediada por diferentes tecnologias. Nossa mente seria estendida ao nosso corpo e ao ambiente que nos cerca, não havendo divisas tal como as preconizadas pelo paradigma cartesiano: mente-corpo e sujeito-objeto.

Todo este arcabouço teórico acerca dos conceitos de engajamento digital e produção de presença culminam na discussão sobre mediação, onde são redefinidos os papéis do aluno, do professor e das tecnologias em sua relação com o conhecimento. A demanda por uma re-corporificação da cognição anteriormente discutida implica, em termos práticos, que professores e alunos passem a perceber os dispositivos tecnológicos como extensão de suas capacidades cognitivas, que atuam especialmente como uma memória estendida.

O conceito de mediação em Vygotsky (2010) orientou o trabalho docente no ambiente online, por oferecer subsídios sobre a relação intrínseca e as características próprias dos processos de aprendizagem e desenvolvimento, indicando as formas e momentos em que o professor deve agir no processo de aprendizagem de modo a contribuir com o desenvolvimento mental/cognitivo de seus alunos. Ao estabelecer que o professor deve reconhecer o nível de 
desenvolvimento real do aluno, identificando de maneira diagnóstica os conhecimentos por ele já consolidados, a mediação acontece sob o pressuposto da colaboração na resolução de problemas, que permite ao aluno atingir sua zona de desenvolvimento proximal, onde consegue, com auxílio do professor e/ou dos pares, desenvolver suas potencialidades na solução de problemas. Em suma, o processo de aprendizagem mediada forja a zona de desenvolvimento proximal, o que denota seu aspecto essencial e condicionante do desenvolvimento mental/cognitivo daqueles que aprendem. Nota-se na perspectiva vygotskyana um pressuposto de mediação que fornece pistas sobre como ressignificar o papel do professor na era digital, na medida em que este deve passar a atuar orientado pela diagnose que identifica o estado de conhecimento dos aprendizes antes de iniciar seu percurso de aprendizagem mediado, o que pode ser facilitado pela adoção de sistemas adaptativos. Com base no diagnóstico situacional dos aprendizes/turmas, o professor detecta os momentos em que deve intervir, podendo configurar uma prática docente ancorada em uma abordagem híbrida, que oferece um leque de metodologias e estratégias que os conduzem à diferentes formas e combinações possíveis para uma intervenção efetiva.

\subsection{O Curso "Aprendizagem Híbrida e Adaptativa: Teoria e Prática"}

Com o intuito de apresentar e discutir os conceitos de aprendizagem híbrida e adaptativa, assim como suas respectivas formas de operacionalização, foi criado o curso "Aprendizagem Híbrida e Adaptativa: Teoria e Prática" no âmbito da JOVAED 2017. O evento e o curso foram amplamente divulgados pela página do Facebook Ambientes Pessoais de Aprendizagem, assim como em grupos de professores, na mesma rede social. Era necessário preencher um formulário de inscrição, cujo link ficou disponível na página do evento, para acessar o curso que decorreu entre os dias 05 e 21 de junho de 2017. Este formulário, elaborado no Google Forms, deveria ser preenchido com as seguintes informações: (i) nome; (ii) e-mail, essencial para permitir acesso ao Google Classroom (Google Sala de Aula), ambiente escolhido para a realização do curso; (iii) cidade/estado/país e (iv) instituição de vínculo. Os cursistas tiveram seus e-mails cadastrados no aplicativo e assim receberam um convite com link para acessar a turma. A seguir são apresentados o aplicativo Google Classroom, com uma breve análise de seu uso em diferentes níveis de ensino, a estrutura do curso e seus resultados. 


\subsubsection{Google Sala de Aula}

O Google Classroom (Google Sala de Aula) é um dos aplicativos do Google Suite for Education e foi criado em colaboração com professores e alunos tendo como objetivos (i) facilitar a comunicação, provendo um ambiente de aprendizagem online organizado por turmas, (ii) promover o acompanhamento do progresso dos alunos e (iii) auxiliar professores e alunos a atingirem melhores resultados, de maneira cooperativa. ${ }^{1}$ Trata-se de um serviço disponibilizado gratuitamente, inicialmente somente para instituições educativas sem fins lucrativos, com contas de e-mail com extensão .edu, e, desde março de 2017, qualquer pessoa com uma conta pessoal de e-mail Google pode se cadastrar e usar o aplicativo, criando e participando de turmas. Entre agosto de 2014 (ano em que foi lançado) e abril de 2018 o aplicativo vem incorporando novas funcionalidades, uma das últimas agregadas permite aos responsáveis por alunos se inscreverem em resumos, enviados por e-mail pelos professores, com o intuito de acompanhar a aprendizagem dos alunos que estão sob sua responsabilidade. ${ }^{2} \mathrm{O}$ aplicativo é integrado aos demais aplicativos Google, como Google Drive, Groups, Hangout, Forms e Calendar, permitindo compartilhamento e armazenamento, aplicação e acompanhamento de atividades.

O Google for Education conta ainda com um Training Center destinado a professores com uma formação embasada no conceito de lifelong learning, disponibilizada de forma gratuita e online, contando com os treinamentos básico e avançado em estratégias para integração do Google em sala de aula, para o uso dos dispositivos tablet Android e Chromebook, além dos cursos de Cidadania Digital e Segurança; Formação de Instrutores e Tools for Diverse Learners Training, estes dois últimos disponíveis apenas em inglês. O centro de treinamento também oferta a possibilidade de certificação como (i) educador certificado nível 1 e nível 2, (ii) instrutor certificado e (iii) inovador certificado. ${ }^{3}$

Segundo dados obtidos no site do Google for Education, o uso do G Suite por professores, para comunicação e colaboração em sala de aula, provê 52 horas a menos de trabalho; redução de $90 \%$ do trabalho de gerenciamento e manutenção

\footnotetext{
${ }^{1}$ https://edu.google.com/intl/pt-BR/products/productivity-tools/classroom/

${ }^{2} \mathrm{https}$ ://support.google.com/edu/classroom/answer/6149237?hl=pt

${ }^{3}$ https://edutrainingcenter.withgoogle.com/
} 
de servidores, suporte e correções do sistema e um retorno de investimento de $329 \%$ para instituições educacionais com fins lucrativos que adotam o G Suite em substituição a uma infraestrutura similar anteriormente utilizada. ${ }^{4}$ Este último dado é corroborado pela pesquisa realizada por Schneiders e Cyrne (2017), onde é analisado o impacto financeiro causado pela adoção do Google Apps for Education em uma universidade privada brasileira. Além da redução nos gastos com equipamentos e serviços de Tecnologia da Informação (TI), a pesquisa identificou uma maior integração entre os setores administrativos e educacional da universidade com o uso dos recursos de compartilhamento, gestão e trabalho colaborativo.

Ao selecionar alguns relatos de experiência, mais recentes, de uso do Google Sala de Aula em diferentes níveis/modalidades de ensino/formação (Bernardo, 2017; Silva e Barcelos, 2017 e Toledo, Rocha e Nunes, 2018) depreende-se algumas conclusões:

1. O incremento da comunicação, interação e colaboração em sala de aula, (presencial e online) é percepcionado por professores e alunos, com destaque à eficiência da funcionalidade feedback, que permite agilidade na devolutiva das atividades e acompanhamento mais proximal e personalizado do progresso das aprendizagens;

2. A conectividade é um item identificado como diferencial, pois leva em consideração a realidade digital na qual estamos inseridos. Alunos usuários podem baixar o aplicativo no celular e realizar atividades em qualquer lugar onde tenham acesso à conexão com a internet, passando a fazer uso educativo da mesma, por mais tempo e com maior variedade. O reconhecimento prévio das potencialidades das tecnologias digitais, de uma maneira geral, é fator crucial para que alunos identifiquem que as mesmas também podem intervir positivamente em seu processo de aprendizagem.

3. O gerenciamento do tempo, onde o aluno, de acordo com os prazos estipulados pelo professor, pode organizar seu fluxo de trabalho é uma das vantagens percepcionadas, em especial porque estimulam a autonomia. A flexibilização tempo/espaço, característica das abordagens híbrida e

\footnotetext{
$\overline{{ }^{4} \text { https://edu.google.com/intl/pt-BR/products/productivity-tools/ }}$
} 
adaptativa, é uma vantagem especialmente sentida por alunos que moram distante ou têm dificuldade de acesso aos espaços físicos onde ocorrem os encontros presenciais, fazendo com que possam recuperar, ao menos em parte, as aprendizagens desenvolvidas presencialmente, na medida em que as mesmas são pensadas de forma concatenada com os momentos online. A otimização de recursos, com a redução ou eliminação do uso do papel, visto que o espaço do aplicativo e os demais aplicativos integrados comportam o material didático e suportam a realização de avaliações, é outra vantagem possível com a adoção da ferramenta.

4. No tocante às aprendizagens comportamentais e atitudinais, o uso da ferramenta em si é um elemento que provoca mudança, na medida em que os alunos precisam aprender a se comportar e agir/interagir neste novo ambiente. Nos AVA institucionais é comum encontrar, dentro dos próprios ambientes/aplicativos, tutoriais para conhecer melhor a ferramenta e suas funcionalidades, assim como documentos tais como contrato didático e netiqueta, onde alunos tem acesso às normas que regem aquele espaço educativo. O aplicativo Google Sala de Aula possui, dentro da própria ferramenta, um link com acesso a tutoriais e central de ajuda, além de apresentar uma interface aberta e amigável, que suporta uso institucional e não institucional, fazendo com que os usuários, professores e alunos, não tenham problemas quanto à usabilidade ${ }^{5}$. Os aspectos mais destacados, no que concerne à mudança comportamental e atitudinal, são o desenvolvimento de maior autonomia na gestão do tempo e organização da aprendizagem e incremento da capacidade criativa, na medida que o uso do aplicativo costuma estar associado a adoção de uma metodologia ativa de aprendizagem, onde há um privilégio de atividades onde o aluno aprende fazendo. Uma maior familiaridade com as funcionalidades do Google Sala de Aula e com os demais aplicativos integrados do Google for Education constituem uma aprendizagem paralela, agregando um conhecimento técnico de ferramentas que podem ser utilizadas em outras aprendizagens assim como em atividades profissionais.

5. Para os professores, o aplicativo é um espaço profícuo para

${ }_{5}^{5} \mathrm{O}$ Help Center, onde se explica o funcionamento do aplicativo e suas funcionalidades, está disponível em uma versão para professores e outra para alunos. https://support.google.com/edu/classroom/?hl=pt\#topic= 
experimentação de abordagens educativas emergentes, na medida em que suas funcionalidades exigem dos alunos uma postura mais autônoma, criativa e cooperativa/colaborativa. Na adoção de uma abordagem híbrida e adaptativa, os alunos percepcionam maior preparo teórico-prático, obtido nos momentos online, para os momentos presenciais.

6. A infraestrutura, mais especificamente o acesso à internet, é apontada por estes estudos como um entrave à efetivação e ampliação do uso do aplicativo. A dificuldade é contornada adotando a perspectiva BYOD (Bring Your Own Device).

\subsubsection{Estrutura do Curso}

Na página inicial do curso, intitulada Mural, as postagens aparecem na sequência prevista pelo professor. As primeiras publicações foram sobre o ambiente Google Classroom e a estrutura do curso. A proposta pedagógica da oferta formativa também se encontra subjacente ao texto, aconcorada na perspectiva de mediação vygotskyana, pautada na curadoria de conteúdos, na noção de par mais capaz, visando a aquisição de novas aprendizagens que se constituam como caminhos para alcançar a zona de desenvolvimento proximal dos cursistas.

A respeito das funcionalidades da plataforma, no ícone com o símbolo de interrogação (?) do lado esquerdo da tela pode-se acessar os seguintes recursos de suporte: (i) o que há de novo, onde se é direcionado à uma página que apresenta as atualizações do aplicativo; (ii) enviar feedback, onde se pode reportar qualquer tipo de problema ocorrido no aplicativo; (iii) faça uma pergunta, onde se é direcionado à página do Google for Education Help Forum e (iv) acessar a ajuda, onde se é direcionado para a página da Central de Ajuda do Google Classroom. Já do lado direito, no ícone com o sinal de mais (+) se encontram as seguintes funcionalidades: (i) reutilizar postagens; (ii) criar pergunta; (iii) criar tarefa e (iv) criar aviso. No menu lateral esquerdo se tem acesso às seguintes opções de configurações: (i) mostrar itens excluídos e (ii) definir quem pode postar e comentar no mural. Ainda neste menu pode-se visualizar as próximas tarefas e navegar pela sala clicando nos tópicos adicionados.

Com a funcionalidade Alunos é possível enviar email, convidar/incluir/excluir/ignorar alunos. Na funcionalidade Sobre, no menu lateral 
esquerdo, temos acesso aos seguintes recursos: (i) pasta da turma no Google Drive, aberta automaticamente quando da criação da turma; (ii) agenda da turma, onde constam os prazos de todas as atividades programadas; (iii) Google Agenda, onde os cursistas podem também visualizar a agenda do curso e atualizar sua agenda pessoal e (iv) professores, canal de comunicação e gerenciamento dos professores da turma. Neste espaço pode-se também editar o nome da turma, incluir uma descrição sobre a mesma e o número da sala. É possível ainda adicionar materiais, que aparecerão no mural da turma, como (i) anexos, que podem estar armazenados em suporte físico ou na nuvem, os mesmos ficarão disponíveis na pasta da turma no Google Drive; (ii) vídeos do YouTube e (iii) links para endereços da web.

No mapa de tarefas é possível visualizar o andamento geral da turma, quantos alunos já enviaram as atividades, quantos já receberam devolutiva da mesma e para quantos falta enviar. Ao enviar resposta para questões e trabalhos, seja na forma de anexos ou comentários, o mesmo passa a aparecer como concluído e, depois de corrigido, como devolvido. O recurso nota é ofertado e pode ser ou não utilizado, tanto na funcionalidade Perguntas como Tarefas. Após uma atualização do sistema, em agosto de 2017, passou a ser possível, em uma única visualização, acompanhar individualmente o progresso dos alunos na realização das tarefas. As atividades onde não se atribui nota passam a constar como devolvida/entregue, até então elas apareciam como pendentes.

\subsection{Discussão e Análise dos Resultados}

O formulário de inscrição do curso Aprendizagem Híbrida e Adaptativa: Teoria e Prática foi respondido por 158 interessados, professores da Educação Básica e do Ensino Superior, pedagogos e coordenadores pedagógicos, licenciandos, mestrandos e doutorandos, técnicos educacionais, designers instrucionais, profissionais de fundações e empresas do ramo educacional, oriundos das cinco regiões do Brasil. Destes, 98 acessaram o Google Classroom e acompanharam o curso.

O conceito de participação e presença em um ambiente de aprendizagem online resguarda especificidades, na medida em que um aluno pode acompanhar um curso, mesmo sem interagir, por isso a análise dos resultados obtidos com as 
respostas das atividades propostas no curso, assim como interação nos posts e fóruns, desconsidera a sua dimensão quantitativa.

O curso foi pensado de forma que assumisse em sua constituição os pressupostos das abordagens híbrida e adaptativa e organizado de forma a usufruir ao máximo de todas as funcionalidades do aplicativo. Nesse sentido, optou-se por usar o recurso de perguntas como 'aquecimento' para a realização das atividades, assim foi criado o tópico Warm-up, onde duas questões (Figuras 1 e 2) norteadoras de todo o curso foram feitas, com espaço para comentários e interação entre os alunos.

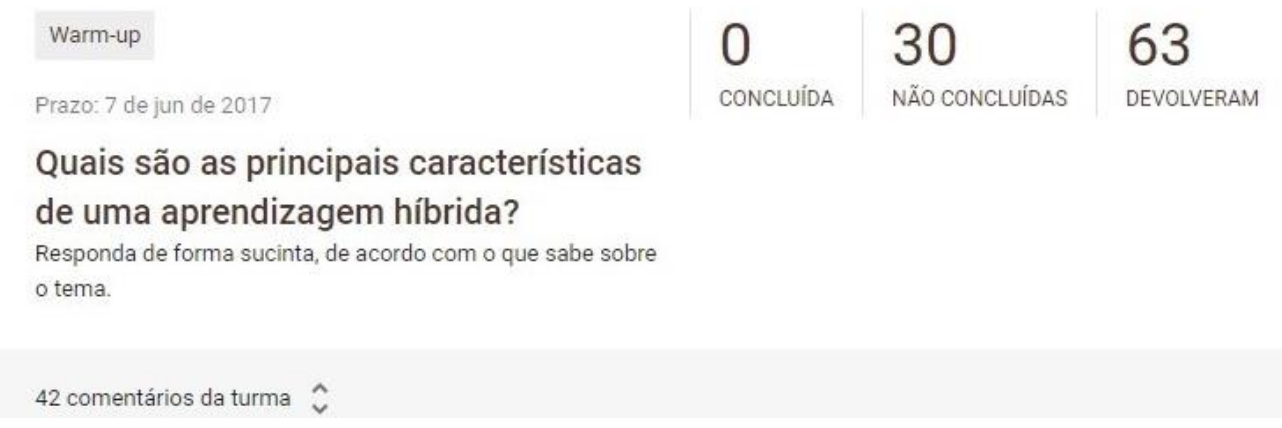

Figura 1: Warm-up Aprendizagem Híbrida

Qual destes termos você considera estar menos relacionado à aprendizagem adaptativa?

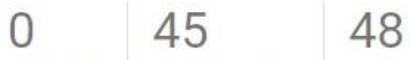

CONCLUIDA NÄO CONCLUIDAS DEVOLVERAM

Personalização

Autonomia

Tecnologia Assistiva

Flexibilidade

Aprendizagem Auto Dirigida

Sistemas de Recomendação

Mediação

Figura 10: Warm-up Aprendizagem Adaptativa

As duas atividades à que foram conferidas notas, Leitura Aplicada e Atividade Prática, propostas após as respectivas perguntas no Warm-up, foram elaboradas com o objetivo de proporcionar a operacionalização e aplicação dos conceitos apresentados e discutidos. Para debater de forma aprofundada as perguntas do Warm-up, relacionando-as às atividades Leitura Aplicada e Atividade Prática, foi criado o tópico Fórum. No primeiro, toda turma foi 
convidada a discutir pensando de forma alinhada e comparativa, a partir de sua resposta à pergunta inicial e dos conhecimentos adquiridos com a atividade Leitura Aplicada, ambos versando sobre o conceito de aprendizagem híbrida. Seguindo a mesma dinâmica, o segundo fórum convidou os 15 alunos que concluíram a Atividade Prática a discutir o conceito de aprendizagem adaptativa, identificando suas características, limites e possibilidades. Como última atividade do curso, os alunos foram convidados a responder um questionário de avaliação do curso.

As duas perguntas propostas no Warm-up cumpriram sua missão de mobilizar o debate sobre os temas em pauta, visto que, além de responder à questão, o que era exigido pela tarefa, os cursistas também se engajaram em trocar ideias entre si nos comentários da atividade. É importante ressaltar que, diferente de um AVA convencional, onde a ferramenta fórum é o local privilegiado de socialização, participação e troca, a estrutura do Google Classroom não compreende esta ferramenta, se aproximando mais, em termos de design, a uma rede social, com posts e comentários. Mesmo se equipararmos as ferramentas comentários e fórum, o nível de interação, tomado no sentido adesão, ultrapassou as expectativas, na medida em que a participação através dos comentários não era computada para a nota - fator que costuma mobilizar a participação - de nenhuma das atividades propostas. Alguns fatores podem ter contribuído para o bom nível de interação nos comentários, tais como, (i) o curso ter sido desenvolvido em um ambiente pouco conhecido à época pelos cursistas, o que gerou curiosidade em experimentar a ferramenta, (ii) a interface amigável e semelhante à redes sociais, (iii) a temática do curso, que sugere engajamento como característica primordial nas abordagens educativas estudadas e (iv) a busca pelo senso de pertença, que invariavelmente aparece quando organizamos a aprendizagem por turmas.

Para ampliar o debate iniciado pelos cursistas nos comentários dos posts referentes às atividades de Warm-up, foi criado um tópico denominado Fórum. Como produto originado das respostas dadas à pergunta sobre o conceito de aprendizagem híbrida, uma nuvem de palavras (Figura 3) foi gerada como síntese das colaborações de cada respondente, tornando-se ponto de partida para novos apontamentos e uma reelaboração, agora coletiva, do conceito. 


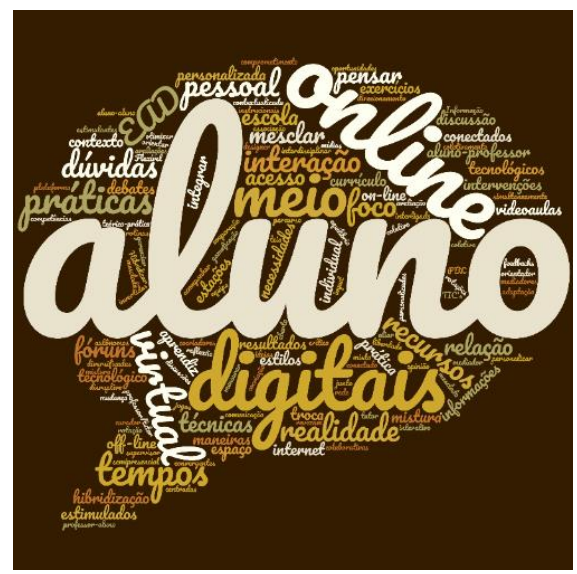

Figura 3: Nuvem de Palavras sobre o Conceito de Aprendizagem Híbrida

A cursista D.M. destacou uma frase, encontrada na nuvem "conectados coletivamente aluno-professor", que segundo ela caracterizaria bem o método de ensino em questão, assim como expressa "a conexão que o aluno precisa para sentir-se seguro em suas dúvidas", traçando um paralelo do trabalho do professor na abordagem híbrida com o processo de orientação de monografia, corroborado pela cursista L.F.S, quando afirma que "o professor deixa de atuar como transmissor do conhecimento para se tornar mediador do processo de ensinoaprendizagem", apontando assim caminhos para discutir a ressignificação do papel do professor na era digital a partir do referencial teórico adotado nesta pesquisa.

$\mathrm{O}$ apontamento supracitado, no qual a cursista identifica a aprendizagem híbrida como método de ensino, me fez intervir e propor à turma uma questão: será que finalmente as barreiras que ainda existem entre o presencial e a Educação a Distância, que são consideradas modalidades de ensino, serão rompidas? Neste ponto a ideia era motivar a reflexão sobre os conceitos de modalidades e métodos de ensino, suas diferenças e confluências, e como sua integração leva ao que denominamos de abordagem educativa. Neste sentido, a cursista D.T. responde a pergunta acima, afirmando, em consonância com a concepção de engajamento digital, que "em um curto espaço de tempo aprendi muita coisa nova, muitos recursos que no meu entender promovem uma maior convergência entre ensino virtual e presencial".

Nas tarefas Leitura Aplicada e Atividade Prática o recurso nota foi utilizado para, além de apresentar a funcionalidade, abrir caminho para uma reflexão sobre avaliação da aprendizagem. Nas propostas das tarefas foram explicitados os critérios avaliativos, que funcionam como um checklist de etapas a serem cumpridas pelos cursistas e de acompanhamento para a mediadora. $\mathrm{O}$ 
objetivo central era fazer com que os cursistas 'colocassem a mão na massa' e pudessem vislumbrar alternativas de aliar teoria e prática, na medida em que foram desafiados a criar um recurso de aprendizagem (não lhes foi ofertada uma definição para tal, somente sugestões de ferramentas a serem utilizadas para sua confecção) a partir de um referencial teórico sobre aprendizagem híbrida, escolhido a partir de uma lista de sugestões. Mapas conceituais, nuvens de palavras, apresentações, infográficos vídeos e animações foram os recursos mais utilizados.

Em Atividade Prática os alunos foram convidados a conhecer e explorar a plataforma Geekie Lab, uma plataforma adaptativa ${ }^{6}$, criada pela empresa Geekie que, destinada ao Ensino Médio, tem por objetivo promover inovação na sala de aula, com maior interatividade, acompanhamento em tempo real da evolução da aprendizagem e otimização do tempo ${ }^{7}$. O objetivo da atividade consistia em oportunizar aos cursistas experimentar a plataforma e identificar se a mesma foi desenvolvida de acordo com os pressupostos da aprendizagem adaptativa elencados na questão do Warm-up. Desta forma os alunos foram instigados a investigar os conceitos correlatos/componentes - personalização, autonomia, flexibilidade, aprendizagem autodirigida, sistemas de recomendação e mediação do que podemos denominar aprendizagem adaptativa.

Os aspectos técnicos foram apontados como algumas das vantagens da ferramenta utilizada, considerada uma plataforma intuitiva, com design limpo e de fácil navegação. A facilidade de acesso e usabilidade foram também destacadas como diferenciais. A acessibilidade para pessoas com deficiência foi apontada como um aspecto a ser considerado, assim como o desenvolvimento de conteúdo para disciplinas técnicas. O cursista G.A levanta um questionamento pertinente: “como saber se é possível tomar ciência do tempo que o estudante levou para a realização das tarefas, se ele assistiu ao vídeo até o final? "Pela descrição dos relatórios disponíveis na versão paga da ferramenta não é possível acompanhar o tempo de uso e permanência na plataforma, como permitido no Moodle por exemplo, mas sim acompanhar quais atividades foram realizadas no período delimitado para a busca da informação. Quanto aos vídeos, na versão trial basta

\footnotetext{
${ }^{6}$ A plataforma é designada como adaptativa pela empresa, que segundo informação disponível em seu site, é a única plataforma adaptativa reconhecida pelo MEC.

${ }^{7} \mathrm{http}: / /$ geekielab.geekie.com.br/
} 
clicar no vídeo que o sistema entende que aquela tarefa foi realizada, é muito provável que o mesmo ocorra na versão paga. É possível saber se o aluno realmente acompanhou o vídeo, usando estratégias que forcem-no a assistir até o fim, como por exemplo, incluindo questões no meio do vídeo, impedindo que o mesmo avance sem as respostas e a tarefa seja marcada como concluída, tal como feito em MOOCs do Coursera.

Um aspecto de caráter pedagógico, apontado como vantajoso tanto para alunos quanto para professores, a funcionalidade que permite o acompanhamento do desempenho nas atividades propostas, de forma automática sem a necessidade de mediação humana, se destaca. A alternância entre textos e vídeos para abordar a conteúdo foi identificada como uma estratégia pedagógica que promove a fixação do conteúdo e colabora para a fluidez ao processo de aprendizagem. A ubiquidade pressuposta pela ferramenta e seus desdobramentos no campo educacional foram sintetizadas pelo cursista F.R:

"A Polegarzinha, uma leitura recomendada, elabora sobre essa juventude que nasceu tendo acesso ao conhecimento humano ao alcance do polegar. A realidade onde as tecnologias independem de licitações e logística governamental. O que há de mais sofisticado em acesso à WEB está nas mãos dos alun@s”. (F.R., Atividade Prática)

A ausência de espaços de interação e colaboração na plataforma foi sentida pela cursista L.F.S, mas se explica pelo fato da mesma estar alinhada aos pressupostos da aprendizagem autodirigida e da sala de aula invertida, fatores identificados pela cursista N.M, que também acredita na customização do material pelo docente da turma como mobilizador do sentido de pertença e engajamento dos alunos. A revisão do conteúdo, proposta quando o aluno não vai bem nas atividades relativas ao mesmo, consiste no redirecionamento para a aula vista anteriormente, sem também oferecer novos exercícios, caracterizando assim um dos limites da ferramenta. A cursista S.S define seu desapontamento com a experiência na plataforma pois, ao seu ver, "pareceu um jeito tradicional de usar a tecnologia: uma aula praticamente expositiva com questionário ao final. Não houve inovação nem autonomia por parte do aluno".

Na versão trial da plataforma o recurso de acompanhamento disponível é o relatório da tarefa, onde constam dados relativos a entrega e acerto por aluno e a média de acerto da turma e por questão, disponível no painel de tarefas (Figura 4). Já na versão paga estão disponíveis relatórios de uso e desempenho e uma tabela de desempenho. 


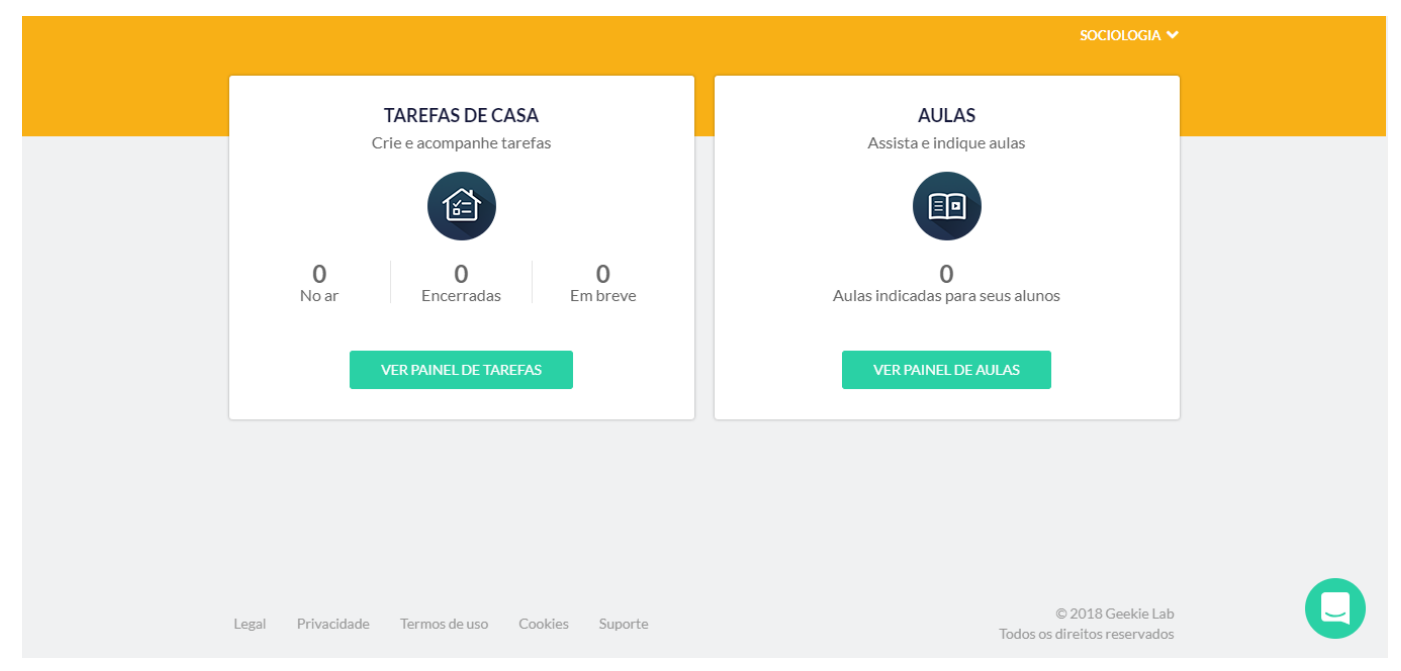

Figura 4:Página inicial Geekie Lab

Alguns cursistas revelaram um certo desconforto com a atividade por não dominarem o seu conteúdo disciplinar. Este é um aspecto curioso pois a atividade não tinha como objetivo avaliar os conhecimentos sociológicos, ainda assim, pelo fato da plataforma oferecer feedback imediato às respostas, os retornos negativos fizeram com que os cursistas reagissem às falhas de maneiras diversas. Esta experiência levanta uma reflexão sobre o quanto as emoções e a forma como lidamos com os erros são preponderantes no processo de aprendizagem.

Partindo do pressuposto de que o termo aprendizagem adaptativa compreende respeitar o tempo, o ritmo e a forma de aprendizagem do aluno, visando uma aprendizagem mais flexível e personalizada, o papel do fórum sobre este conceito foi fomentar a reflexão, consubstanciada pela experiência na utilização do Geekie $L a b$, através das seguintes questões: Podemos realmente falar em aprendizagem adaptativa? Podemos alcançar o nível de personalização exigido para termos a adaptação da aprendizagem? Um dos pontos levantados pelos cursistas que mais chamou atenção foi sobre a questão da flexibilização em relação aos conteúdos, para além do tempo, ritmo e forma de aprendizagem, o que demonstra um pensamento alinhado às discussões sobre flexibilização curricular em curso no Brasil $^{8}$. Outro elemento que compõe o pressuposto de flexibilização, a acessibilidade - relativa ao acesso através de diferentes suportes e sistemas

\footnotetext{
${ }_{8}^{8}$ No Brasil foi recentemente aprovada, em 2017, a Base Nacional Comum Curricular da Educação Infantil e do Ensino Fundamental, permanecendo em discussão a Base do Ensino Médio, alvo de críticas por estabelecer inicialmente, referências apenas para os componentes curriculares obrigatórios, Língua Portuguesa e Matemática. A modificação da estrutura curricular neste nível de ensino foi proposta por medida provisória em 2016 e é conhecida como Reforma do Ensino Médio. Mais informações em: http://basenacionalcomum.mec.gov.br/
} 
operacionais -, também foi lembrado pelos cursistas e teve sua presença identificada na plataforma. Uma ausência sentida foi a de atividades que mobilizassem de forma mais efetiva a motivação dos alunos, claramente vinculadas à experiências de aprendizagem onde o aluno tivesse seu potencial criativo e investigativo estimulado. Em síntese, o grupo percebeu algumas das características elencadas como constituintes da aprendizagem adaptativa, tais como aprendizagem autodirigida e sistemas de recomendação, mas, ao perceber a ausência de outras, como a mediação e autonomia, identificaram que a plataforma atinge apenas alguns níveis de adaptação da aprendizagem.

\begin{abstract}
“(...) se observarmos os recursos da plataforma ela também atende, mesmo que parcialmente, ao propósito de aprendizagem autodirigida quando oferece ao aluno a possibilidade de testar o que aprendeu, avaliar seu conhecimento, revisar conteúdos e ainda ir em busca de outros materiais, assim como o recurso de relatório, penso que atenda a proposta de sistema de recomendação, visto que com base nos resultados do aluno é possível intervir ou mediar, recomendando conteúdos e outras atividades. A plataforma Geekie também oferece certa flexibilidade na medida em que pode ser acessada por meio de dispositivos móveis, porém necessita de acesso à internet. " (D.T., Fórum: Conceito de Aprendizagem Adaptativa)
\end{abstract}

Alguns cursistas sentiram falta de tutoriais, para o uso dos ambientes e ferramentas explorados no curso (vale lembrar que, no início do curso, foi sugerida uma lista de tutoriais para o uso do Google Classroom), o que pode estar vinculado a um sentimento de inabilidade e insegurança, ainda persistente, em relação ao uso de novas tecnologias e aplicativos digitais, mas também a uma lacuna na formação docente: o desenvolvimento de competências e habilidades que estimulem e promovam a autonomia e criatividade dos futuros professores. É necessário ultrapassar esta dificuldade, pois é de suma importância que os professores tenham uma postura proativa, baseada na experimentação e investigação, para que estas abordagens educativas emergentes se consolidem e possam desvelar todo seu potencial.

O retorno positivo dos cursistas, desde o início do curso, identificando no mesmo sua essência 'metalinguística' confirma que o mesmo cumpriu com seus objetivos de abordar os temas aprendizagem híbrida e adaptativa em suas dimensões teórica e prática, mobilizando um trabalho sob uma perspectiva de interação e colaboração, assim como a aposta na ressignificação do papel do professor a partir do pressuposto da mediação. 
“(...), através das leituras e de nossas interações pude conhecer melhor sobre a aprendizagem híbrida e já estou aplicando algumas práticas em meu trabalho, pois acredito que o aluno deverá ser sempre o principal e o foco de todas as ações e por isso devemos ter uma visão ampla das formas de aprendizado visando a flexibilização, dinamização e modernização das formas de aprender". (A.F. Fórum: Conceito de Aprendizagem Híbrida).

"Cursos como este, que nos possibilitam vivenciar o que proporemos aos alunos, com um conteúdo real e as atividades para aferir a aprendizagem, nos retiram o peso de ser o "detentor do conhecimento" e nos colocam como sujeitos que participam do processo de aprendizagem.” (G.A. Atividade Prática)

\title{
Qual a sua motivação para acompanhar o minicurso?
}

\section{5 responses}
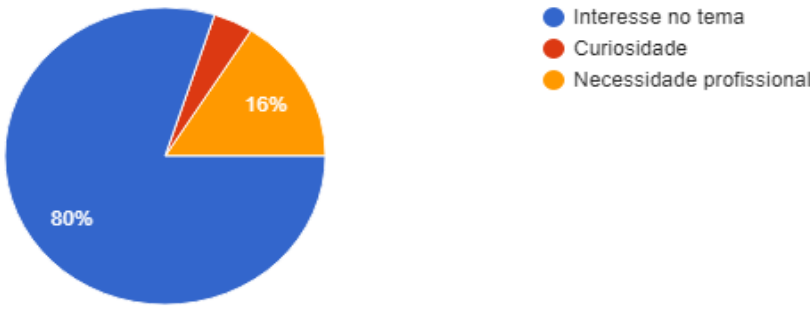

Figura 5:Motivação para acompanhar o curso. Fonte: autoria própria.

\begin{abstract}
Contribuição para a aprendizagem sobre Aprendizagem Híbrida e Adaptativa:
\end{abstract}

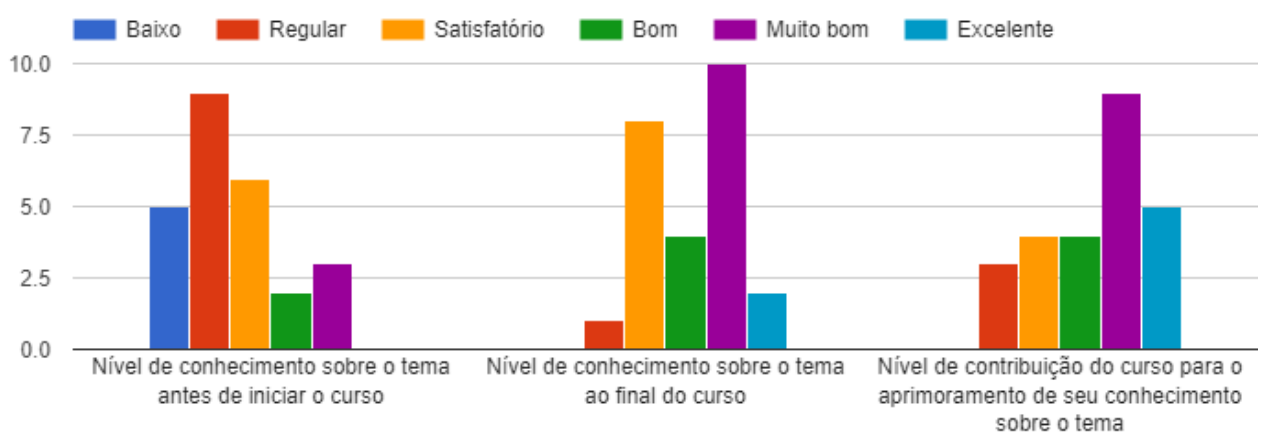

Figura 6:Contribuições do curso. Fonte: Autoria própria.

Como última atividade, os cursistas foram convidados a responder um questionário de avaliação do curso, cujos resultados confirmam o que pôde ser observado ao longo do curso: há uma demanda em conhecer e se apropriar destas novas abordagens educativas mediadas pelas tecnologias digitais, mesmo tempo em que se confere a mediação da professora um fator fundamental para o 
engajamento no curso e promoção de aprendizagens que levem ao nível de desenvolvimento real, onde se pode mobilizar e operar de forma independente o conhecimento, conforme observado nas respostas à questão aberta "Qual aspecto do curso você considera mais útil ou válido?"

Como Vygotsky não contempla em sua teoria a questão do digital e da aprendizagem em ambientes virtuais e, por isso, a discussão sobre presença inexiste, foi imprescindível buscar aporte em Gumbrecht (2010) para discutir o processo de 'virtualização da presença'. A obliteração dos efeitos de presença como consequência da supremacia da visão hermenêutica do mundo e do paradigma cartesiano, produziu contemporaneamente uma necessidade, um fascínio pela presença, onde os meios de comunicação, as tecnologias têm um papel fundamental. Nesse sentido é importante refletir sobre o impacto das arquiteturas pedagógicas dos ambientes utilizados nas propostas formativas sobre os aprendizes, no quanto as características técnico-pedagógicas que os consubstanciam afetam as reações dos indivíduos, compreendidos a partir das noções de mente corporificada e mente estendida. Se por um lado, em qualquer ambiente virtual de aprendizagem, o acompanhamento do aprendiz e de seu processo de aprendizagem é mais proximal, devido ao processo de virtualização da presença, por outro lado o desenho do ambiente pode causar constrangimentos, na medida que o desenvolvedor tem objetivos próprios, que podem não coincidir e/ou atender às expectativas de seus usuários. Na experiência em questão, o alinhamento entre os requisitos técnicos e pedagógicos assim como a adoção da mediação vygotskyana como elemento central da proposta formativa demonstram que, em uma perspectiva que vise a formação integral do aprendiz, é necessário vislumbrar o processo de aprendizagem para além do processamento de informações e sua consequente representação. Nesse sentido, ambientes que suportem modelos híbridos e adaptativos podem se constituir numa possibilidade, através da virtualização da presença, de oscilação entre efeitos de presença e efeitos de sentido em nossa relação com o mundo e com o conhecimento. 


\subsection{Considerações Finais}

Uma das condições necessárias à realização desta pesquisa foi a disponibilidade de imersão no objeto de estudo, o que significou conhecer de maneira aprofundada as ferramentas que serviram de suporte e de recursos para a elaboração e desenvolvimento das propostas formativas. Trabalhar a partir da lógica de produção de conteúdo e como designer do ambiente de aprendizagem foram as principais contribuições advindas do uso do Google Sala de Aula.

Oferecer um curso sobre abordagens educativas ainda pouco conhecidas em uma ferramenta que acabara de ser liberada para uso de pessoas físicas e, portanto, desconhecida da grande maioria dos inscritos, se transformou em um estimulante desafio 'metalinguístico', na medida em que o uso de uma tecnologia emergente foi usado como espaço de discussão e aprendizagem sobre abordagens também emergentes. A implementação bem sucedida de uma mediação vygotskyana, que buscou despertar a curiosidade e o interesse dos cursistas, fornecendo pistas sobre as questões colocadas, que fomentou a interação colaborativa entre os cursistas e onde o professor mediador é antes de tudo um orientador, demonstrou que estes mecanismos/estratégias de aprendizagem cumprem com seu objetivo de atingir a zona de desenvolvimento proximal dos alunos, o que pôde ser constatado tanto nas interações dos fóruns e, principalmente, nas atividades que requisitaram aos alunos que selecionassem e produzissem conteúdos em diferentes ferramentas, demandando que fossem além de níveis de desenvolvimento já atingidos e habilidades já conquistadas.

À guisa de conclusão, a experiência comprovou o quanto a proposta de utilização de um ambiente virtual de aprendizagem desloca o professor para as funções de designer de conteúdos e curador de informações, o que demanda uma reformulação das políticas de formação inicial e continuada de professores, para que os currículos e práticas passem a estar alinhados a este novo ethos docente. 


\section{Estudo 3 - Formação Inicial de Professores na Era Digital: Desafios e Potencialidades para a Adoção de Modelos Educativos Híbridos e Adaptativos}

Resumo: A pesquisa analisou a formação inicial de professores para o uso de tecnologias digitais sob três aspectos: as políticas públicas de formação inicial docente, a inserção da tecnologia nos currículos e a percepção de professores que atuam nas licenciaturas das instituições investigadas. $O$ objetivo central foi investigar a adoção de abordagens educativas, especialmente modelos híbridos e adaptativos, mediadas pelas tecnologias digitais, procurando identificar sua incorporação às políticas, ao currículo e à prática docente na formação inicial. Para tanto, se procedeu em uma primeira etapa à uma análise documental, que procurou mapear as principais políticas educacionais vigentes que regulamentam a formação inicial no Brasil e identificar a inserção da tecnologia no currículo das instituições investigadas. Em uma segunda etapa se procedeu à elaboração e validação de um questionário que foi aplicado entre fevereiro e maio de 2018 para 32 professores de três universidades do Rio de Janeiro, afim de detectar suas percepções acerca do uso de tecnologias digitais em sua prática docente. As percepções dos professores respondentes encontram consonância com os princípios ensejados às políticas públicas de educação e tecnologias vigentes, na medida que percepcionam o computador e as tecnologias, em especial a conectividade, como meios de ampliação das possibilidades educativas, sem que para isso se prescinda do papel do professor, que precisa assumir cada vez mais uma postura de curador. Entretanto, alguns entreves se colocam à apropriação das tecnologias digitais na formação inicial: estrutura curricular deficitária em disciplinas específicas de tecnologia; defasagem na formação em tecnologia dos professores formadores; problemas de infraestrutura no campus, em especial de conectividade.

Palavras-chave: Aprendizagem Híbrida; Aprendizagem Adaptativa; Formação de Professores; Currículo; Politicas de Tecnologia Educativa.

\subsection{Introdução}

Quando se discute os caminhos de uma educação mediada pelas tecnologias digitais, é importante levar em consideração as implicações que a mudança nos 
papéis de aluno e professor trazem a esse processo. Não se trata somente de uma mudança didático-metodológica - o que já seria muita coisa - mas sim de uma transformação cultural e paradigmática que prevê alterações substanciais nas relações estabelecidas entre estes atores em seus espaços de aprendizagem, assim como redirecionamentos das políticas educacionais no que tange ao currículo tanto da Educação Básica quanto da Formação de Professores. A principal implicação reside na ressignificação do ensinar que emerge da realidade digital em que estamos inseridos e demanda uma reformulação curricular que atenda às necessidades formativas, por um lado dos professores, que precisam realinhar seu modus operandi, e por outro dos alunos, que precisam desenvolver competências e habilidades para profissões que sequer existem.

Segundo Nóvoa (2000) estamos diante de dois desafios, um teórico e outro prático, no que concerne a instituição de um ethos docente. No campo teórico "as fragilidades conceituais das Ciências da Educação provocam uma necessidade de afirmação com base nos paradigmas científicos dominantes, o que dificulta a emergência de novas perspectivas", esta "ausência de uma teoria de formação dos adultos, que forneça um suporte sólido à elaboração de modelos inovadores e à realização de práticas alternativas" (p.19) se coloca como um desafio a ser vencido. Em um evento realizado pela Universidade do Porto intitulado "O Tempo dos Professores", o autor instiga jovens pesquisadores da educação a pensar num saber docente específico, e não mais num saber dicotomizado, onde de um lado se defende que o professor precisa deter uma arcabouço teórico-crítico e, de outro, que o professor precisa dominar técnicas de gestão de sala de aula. Para o bom exercício da docência não há dúvidas de que é necessário se municiar de ambas as competências, porém, como equilibrar? Que outros elementos são necessários para conjugar um saber docente tal como nos propõe Nóvoa?

Para Gatti (2018) o discurso inscrito na formação de professores no Brasil ainda relega o conhecimento pedagógico, destacando que na licenciatura em pedagogia, que prepara os docentes para o exercício da profissão na educação infantil e alfabetização, há uma preocupação maior do que nas demais licenciaturas, que preparam para atuação nos Ensinos Fundamental e Médio, no tocante a oferta de sólida formação em educação, tratando assim a licenciatura como apêndice do bacharelado, concluindo que politicamente, essa discussão de currículo nunca foi levada muito a sério e que a ideia de que o conteúdo prevalece sobre as 
metodologias de ensino assim como a dissociação dessas metodologias dos conteúdos curriculares, são os fatores desencadeadores da crise da formação inicial docente.

Segundo Martins (2015), à docência é uma profissão de base científica e reflexiva e os modelos de formação de professores são mais evolutivos do que disruptivos. Nesse sentido, a formação inicial deve ser encarada como uma etapa fundamental com a ressalva de que não lhe cabe antecipar e/ou resolver todos os problemas de educação e formação. A compreensão da natureza da profissão docente, o ser professor, é condição sine qua non e ponto de partida para uma formação inicial de professores baseada no binômio educação-formação onde a primeira é compreendida como um valor, uma meta a alcançar tendo a instrução escolar como um dos meios para a sua consolidação.

Esta pesquisa procurou identificar os entrelaçamentos existentes entre currículo, políticas de formação de professores e políticas de informática/tecnologia educativa no contexto brasileiro e seus desdobramentos na ponta, mas detidamente na formação inicial de professores, a partir de suas percepções e relatos sobre a prática docente e as políticas que as regulam, afim de identificar os limites e possibilidades na adoção de abordagens educativas híbridas e adaptativas. Na primeira seção deste trabalho é apresentada a metodologia utilizada, com a justificativa quanto a escolha do questionário como instrumento de coleta de dados e a descrição das etapas que envolveram sua elaboração, validação e aplicação. A pesquisa também recorreu à análise documental, para extração de dados de documentos oficiais, e análise de conteúdo, para extração de dados obtidos com as perguntas abertas do questionário, e dos currículos analisados; ambas as técnicas são também descritas nesta seção. Na segunda seção se procede à análise das políticas públicas de formação de professores e tecnologia/informática na educação, com vistas a compreensão de como foram engendradas e estão entrelaçadas. $\mathrm{Na}$ terceira seção são apresentadas e analisadas as propostas curriculares de tecnologias na educação das instituições investigadas. Na quarta seção são apresentadas e analisadas as percepções e relatos dos formadores de professores, obtidas através de questionário. Na quinta seção são tecidos os comentários finais, que visam uma triangulação entre as percepções e relatos dos professores respondentes, as políticas de formação docente e seus currículos, e os limites e potencialidades das tecnologias digitais na educação. 


\subsection{Metodologia}

Esta pesquisa teve como objetivo central investigar, no âmbito da formação inicial docente brasileira, a adoção de abordagens educativas emergentes mediadas pelas tecnologias digitais, procurando identificar sua incorporação ao currículo e à prática docente. Para tanto se procedeu em uma primeira etapa à uma análise documental (FONSECA, 2002), que teve dois objetivos: (i) mapear as principais políticas educacionais vigentes nas áreas de educação e tecnologia e formação inicial de professores. (ii) identificar a inserção da tecnologia no currículo das instituições investigadas, a saber, PUC Rio, UERJ e UFRJ, através da leitura e análise categorial temática (BARDIN, 1977) de ementas das disciplinas que abordam a relação entre TIC e educação como temática central. Em uma segunda etapa se procedeu a elaboração e validação de um questionário que foi aplicado entre fevereiro e maio de 2018 para professores das três universidades acima mencionadas.

A etapa de análise documental, no tocante ao exame das políticas educacionais, se subdividiu nos seguintes momentos: (i) busca e seleção dos documentos a serem analisados; (ii) leitura dos documentos; (iii) classificação e categorização dos dados extraídos dos documentos. Procurou-se identificar os objetivos, principais ações, atores envolvidos e proposta de incorporação das TIC à educação. Para a análise dos currículos dos cursos de licenciatura oferecidos na modalidade presencial pelas três instituições investigadas, PUC Rio, UERJ (Campus Maracanã) e UFRJ (Todos os campi localizados na cidade do Rio de Janeiro) obedeceu-se aos seguintes critérios de busca e seleção: (i) grades curriculares e ementas de disciplinas disponíveis online no site oficial da instituição; (ii) disciplinas oferecidas pelos Departamentos de Educação ou pelos departamentos específicos dos cursos de licenciatura; (iii) disciplinas que apresentam em seu título e/ou ementa indicação de que abordam aspectos relacionados a discussão e/ou aplicação da relação educação-tecnologias. A partir da leitura das ementas emergiram dois eixos norteadores para a análise: no primeiro eixo foram alocados os conteúdos disciplinares de abordagem teórica segundo três categorias: (i) Fundamentação, (ii) Políticas e Legislação e (iii) Recursos. No segundo eixo foram alocados os conteúdos disciplinares de abordagem 
prática/aplicada segundo cinco categorias: (i) Instrumental, (ii) Produção, (iii) Avaliação, (iv) Curadoria e (v) Mediação.

A escolha do questionário online como instrumento de coleta de dados foi ancorada em Hill e Hill (2016) e visou atingir um número de respondentes que permitisse analisar a interface tecnologias digitais e educação na formação inicial de professores. Esta etapa foi dividida em três momentos: (i) elaboração; (ii) aplicação e (iii) análise dos dados obtidos. Na fase de elaboração, realizou-se um estudo preliminar para identificar questionários existentes com proposição similar a desta pesquisa, fundamental para a sua validação. Como referência para algumas das questões utilizadas no questionário, utilizou-se o instrumento de Espinosa (2010). O questionário foi organizado em cinco partes: (i) caracterização, onde se obteve o perfil dos respondentes; (ii) atuação e uso das TIC, onde os professores relataram sua experiência com as TIC nas disciplinas ministradas; (iii) mediação e avaliação, onde os professores relataram o uso que fazem das TIC para estes fins; (iv) abordagens educativas emergentes, onde os professores puderam relatar suas experiências na adoção destas abordagens e (v) percepção sobre currículo e TIC na educação, onde os professores foram questionados sobre as políticas de flexibilização curricular. Na fase de aplicação o primeiro contato foi feito por email com os coordenadores das licenciaturas para a divulgação do link do questionário (anexo), que ficou disponível na plataforma LimeSurvey. Na última fase, se procedeu à análise dos dados com o auxílio do software de análise estatística SPSS, para a análise descritiva dos dados e análise de conteúdo das respostas às perguntas abertas. O questionário foi respondido por 31 professores, sendo 2 da PUC Rio, 7 na UERJ e 22 da UFRJ.

\subsection{Políticas Públicas de Tecnologia e Formação Inicial de Professores no Brasil}

As principais políticas direcionadas à aplicação das tecnologias à educação remontam a década de 80 , primeiramente com a realização do I Seminário Nacional de Informática na Educação, onde as ideias embrionárias do que viria a ser a política pública na área foram discutidas. Em 1983, sob a tutela da Comissão Especial Informática na Educação, subordinada à Secretaria Especial de Informática, o Projeto EDUCOM é criado com dois objetivos centrais: levar computadores às escolas públicas brasileiras e fomentar o desenvolvimento da pesquisa de caráter 
multidisciplinar visando a aplicação da informática no processo de ensinoaprendizagem. O projeto passa a ser coordenado pelo Centro de Informática do Ministério da Educação onde foi implementando através da criação de cinco centros piloto, instalados na Universidade Federal do Rio de Janeiro, na Universidade Federal de Minas Gerais, na Universidade Federal de Pernambuco, na Universidade Federal do Rio Grande do Sul e na Universidade Estadual de Campinas, que desenvolveriam experimentos acerca da utilização do computador nas escolas, avaliando os efeitos da aplicação das tecnologias à aprendizagem, à prática docente e à organização escolar. A criação de disciplinas de informática aplicada à educação e tecnologia na educação nos cursos de licenciatura de algumas das universidades participantes demonstra consonância com esta investigação, na medida em que a formação inicial de professores se constitui como componente estratégico na efetivação de políticas na área, assim como em variável latente em estudos que visam compreender a relação educação-tecnologias. (NASCIMENTO, 2009)

Em 1989, uma política de âmbito nacional é criada, o Programa Nacional de Informática Educativa (PRONINFE ${ }^{1}$ ), visando à aplicação da informática na Educação Básica e no Ensino Superior, a partir da ampliação dos centros de experimentação, consolidação de pesquisas e capacitação docente. Em 1997, a política é atualizada, sendo instituído o Programa Nacional de Tecnologia Educacional (PROINFO) ${ }^{2}$, que se estruturou de forma descentralizada, sendo responsabilidade do governo federal a oferta de equipamentos, em especial computadores e softwares e a produção e disponibilização de recursos digitais de aprendizagem; a responsabilidade quanto a infraestrutura necessária para recepção dos equipamentos e formação docente para seu uso coube aos municípios e estados e se organizou na forma de núcleos de tecnologia. Em sua atualização em 2007 passa a se chamar Proinfo Integrado, quando também contempla a formação de professores como parte do escopo da política a nível federal, porém com foco na formação continuada.

O Programa de Inovação Educação Conectada, em vigor atualmente, é resultado de uma composição de iniciativas já introduzidas e da atualização de algumas ações em andamento articuladas à política predecessora, o PROINFO

\footnotetext{
${ }^{1}$ Instituído pela Portaria Ministerial n. 549/89, de 13 de outubro de1989.

${ }^{2}$ Decreto 6.300/2007 que dispõe sobre o Programa Nacional de Tecnologia Educacional -ProInfo. Disponível em: http://www.planalto.gov.br/ccivil_03/_ato2007-2010/2007/decreto/d6300.htm
} 
Integrado. O programa foi instituído pelo Decreto 9.204/2017 e complementado pela Portaria 1591/2017, que institui o Comitê da Plataforma Integrada de Recursos Educacionais Digitais - REDs, de caráter consultivo, no âmbito do Ministério da Educação e também pela Portaria 1602/2017, que dispõe sobre a implementação, junto às redes de educação básica municipais, estaduais e do Distrito Federal, das ações do Programa de Inovação Educação Conectada. Em articulação com as metas do PNE 2014-2024, apresenta um conjunto de diretrizes nacionais, que contou com a colaboração do Centro de Inovação para a Educação Brasileira $(\mathrm{CIEB})^{3}$ em sua elaboração, que visa acelerar a incorporação de tecnologia e inovação nas escolas públicas brasileiras por meio de uma oferta balanceada de conexão à internet, conteúdos educacionais digitais e formação de professores por meio da universalização do acesso à internet em alta velocidade e do estímulo ao uso pedagógico de tecnologias digitais na educação básica ${ }^{4}$. Uma das estratégias de apoio à execução da política é a Plataforma Integrada de Recursos Educacionais Digitais - MEC RED 5 , criada em 2015 como iniciativa do MEC, que objetivou reunir e disponibilizar recursos educacionais digitais em um único lugar, possui uma interface que combina características de um repositório de conteúdos e de rede social, foi estruturada como ferramenta colaborativa, tendo sido desenvolvida em parceria com a Universidade Federal de Santa Catarina (UFSC), Universidade Federal do Paraná (UFPR) e professoras(es) da Educação Básica. O acordo de cooperação técnica assinado em 2018, que "pretende combinar esforços de órgãos e entidades da União, estados, Distrito Federal, municípios, escolas, setor empresarial e sociedade civil no intuito de assegurar a inserção da tecnologia como ferramenta pedagógica de uso cotidiano nas escolas públicas de educação básica”6 e agrega entidades da sociedade civil como colaboradoras da plataforma. A plataforma Evidências ${ }^{7}$, se configura como uma segunda estratégia de suporte ao atingimento dos objetivos da política. Desenvolvida em parceria pela Universidade Federal de Alagoas e pela Universidade de São Paulo, a partir de editais lançados,

\footnotetext{
3 O CIEB é uma organização sem fins lucrativos, criada em 2016, que atua na formulação de conceitos, desenvolvimento de protótipos e disseminação de conhecimentos e boas práticas de uso de tecnologia nas escolas de nível básico. Fonte: http://www.cieb.net.br/quem-somos/\#quemsomos.

${ }^{4}$ http://portal.mec.gov.br/index.php?option=com_docman\&view=download\&alias=77481-perguntas-erespostas-pdf\&category_slug=novembro-2017-pdf\&Itemid=30192

5 https://plataformaintegrada.mec.gov.br/home

${ }^{6} \mathrm{http} / / /$ portal.mec.gov.br/ultimas-noticias/211-218175739/63331-plataforma-de-recursos-educacionais-ganhanovos-colaboradores-e-sera-ainda-mais-util-ao-professor

${ }^{7}$ https://tecnologiaeducacional.mec.gov.br/
} 
recebe propostas de tecnologias educacionais desenvolvidas por pessoa jurídica que devem estar de acordo com critérios tecnológicos, educacionais e de acessibilidade para compor o guia de tecnologias lançado periodicamente pelo MEC, e que tem por objetivo listar os recursos/serviços tecnológicos que podem ser adquiridos/usados pelas escolas públicas brasileiras, através de avaliação e precificação feita por especialistas.

A legislação atual acerca da inserção e uso das tecnologias na educação precisa ser analisada em conjunto à legislação que dispõe sobre a formação de professores, devido aos entrelaçamentos e influência mútua entre as respectivas políticas. O Plano Nacional de Educação (2014-2024) em vigor, em sua meta 15, pressupõe a formulação de uma política nacional de formação de professores, cuja estratégia 15.6 propõe "promover a reforma curricular dos cursos de licenciatura e estimular a renovação pedagógica, de forma a assegurar o foco no aprendizado do(a) aluno(a), dividindo a carga horária em formação geral, formação na área do saber e didática específica e incorporando as modernas tecnologias de informação e comunicação, em articulação com a base nacional comum dos currículos da educação básica, de que tratam as estratégias 2.1, 2.2, 3.2 e 3.3 deste PNE."8

O Decreto 8.752/2016, que dispõe sobre a Política Nacional de Formação dos Profissionais da Educação Básica tem como um de seus objetivos "promover a atualização teórico-metodológica nos processos de formação dos profissionais da educação básica, inclusive no que se refere ao uso das tecnologias de comunicação e informação nos processos educativos" (Art. $3^{\circ}$, IX), porém em nenhum momento é descrito no documento, de forma diretamente relacionada ao uso das TIC, como se promoverá essa atualização; o único indicativo objetivo encontrado refere-se à interlocução com programas e ações integrados e complementares, pelo qual se deverá estimular a "revisão da estrutura acadêmica e curricular dos cursos de licenciatura, em articulação com as Diretrizes Curriculares Nacionais e com a Base Nacional Comum Curricular (BNCC) da Educação Básica" (Art.12, V), visto que a BNCC pretende definir os direitos de aprendizagem com o desenvolvimento de competências gerais, uma delas a digital:

"Compreender, utilizar e criar tecnologias digitais de informação e comunicação de forma crítica, significativa, reflexiva e ética nas diversas práticas sociais (incluindo as escolares) para se comunicar, acessar e disseminar informações, produzir conhecimentos, resolver

\footnotetext{
${ }^{8}$ Disponível em : http://www.planalto.gov.br/CCIVIL_03/_Ato2011-2014/2014/Lei/L13005.htm.
} 
problemas e exercer protagonismo e autoria na vida pessoal e coletiva." (BNCC, 2017, p.9)

“(...) selecionar e aplicar metodologias e estratégias didáticopedagógicas diversificadas, recorrendo a ritmos diferenciados e a conteúdos complementares (...); selecionar, produzir, aplicar e avaliar recursos didáticos e tecnológicos para apoiar o processo de ensinar e aprender. (BNCC, 2017, p.17)

A recém lançada Política Nacional de Formação de Professores ${ }^{9}$ expressa seu embasamento no diagnóstico de uma formação inicial de baixa qualidade e "um histórico de currículos extensos com ausência de atividades práticas e estágios curriculares sem planejamento e sem vinculação com as escolas.” Este se apresenta como ponto pacífico entre Ministério da Educação e pesquisadores da área, todos reconhecem que há um desequilíbrio entre a formação teórica e prática dos futuros docentes e que isto precisa ser ajustado. A dissenção começa no que se refere à implementação da mudança. Os dados do Censo da Educação Superior dos anos de 2015 e 2016 (Figuras $1^{10}$ a 4) revelam a supremacia da rede privada no que se refere ao número de matrículas nos cursos de licenciatura $(62,9 \%)$, sendo que mais da metade destes alunos estuda na modalidade a distância (59,3\%).

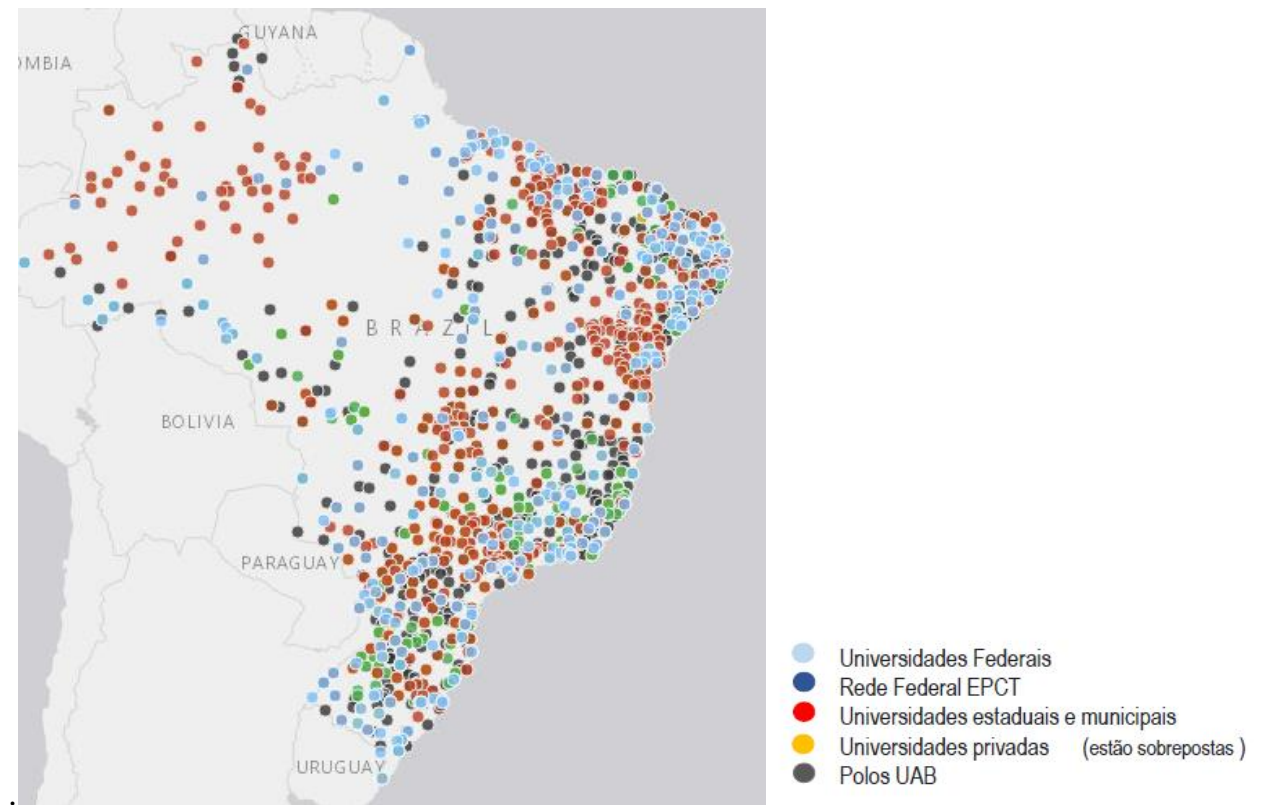

Figura 1: Distribuição da rede universitária brasileira. Fonte: Apresentação da Política Nacional de Formação de Professores, 2017.

\footnotetext{
9 Apresentação da Política Nacional de Formação de Professores, 2017. Disponível em: http://portal.mec.gov.br/docman/outubro-2017-pdf/74041-formacao-professor-final-18-10-17-pdf/file

10 A legenda indica que os dados referentes às universidades privadas estão sobrepostos aos dados referentes às universidades estaduais e municipais. Para confirmação desta informação recorreu-se aos dados do Censo da Educação Superior 2016, que apontam a rede privada como detentora de 62,9\% do número de matrículas nos cursos de licenciatura.
} 


\section{Cursos de Licenciatura}

Número de matrículas em cursos de licenciatura por modalidade de ensino - Brasil 2006-2016

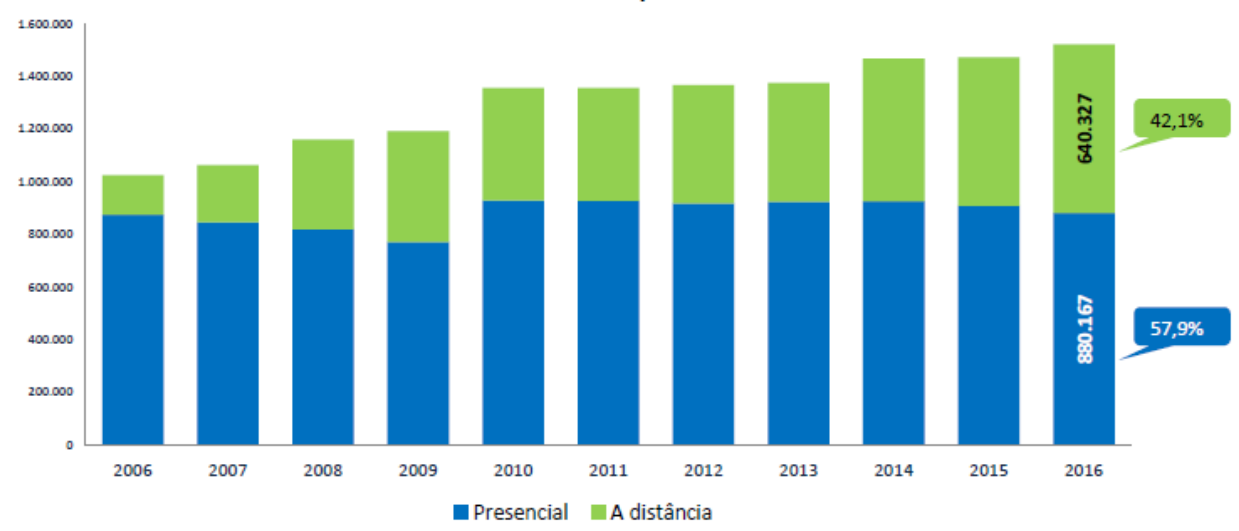

1.520.494 alunos frequentam cursos de licenciatura no Brasil, o que representa $18,9 \%$ do total de alunos na educação superior de graduação.

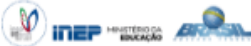

Figura 2: Série Histórica 2006-2016- Evolução do número de matrículas na licenciatura por modalidade. Fonte: Censo da Educação Superior, 2016.

\section{Cursos de Licenciatura}

Distribuição dos $\mathbf{1 . 5 2 0 . 4 9 4}$ alunos que frequentam cursos de licenciatura no Brasil em 2016

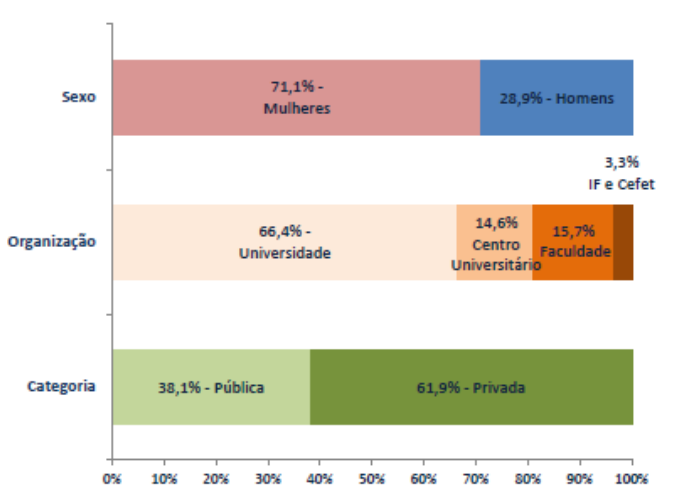

Pública

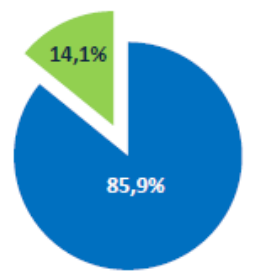

घ Presencial \# A distância

Privada
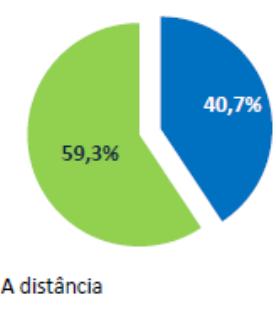

O aluno típico dos cursos de licenciatura é do sexo feminino e estuda em uma universidade. Mais de $85 \%$ dos estudantes de licenciatura de instituiçōes públicas frequentam cursos presenciais. Na rede privada prevalece os cursos a distância, com quase $60 \%$ dos alunos.

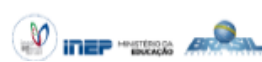

Figura 3: Distribuição de alunos dos cursos de licenciatura por rede. Fonte: Censo da Educação Superior, 2016. 


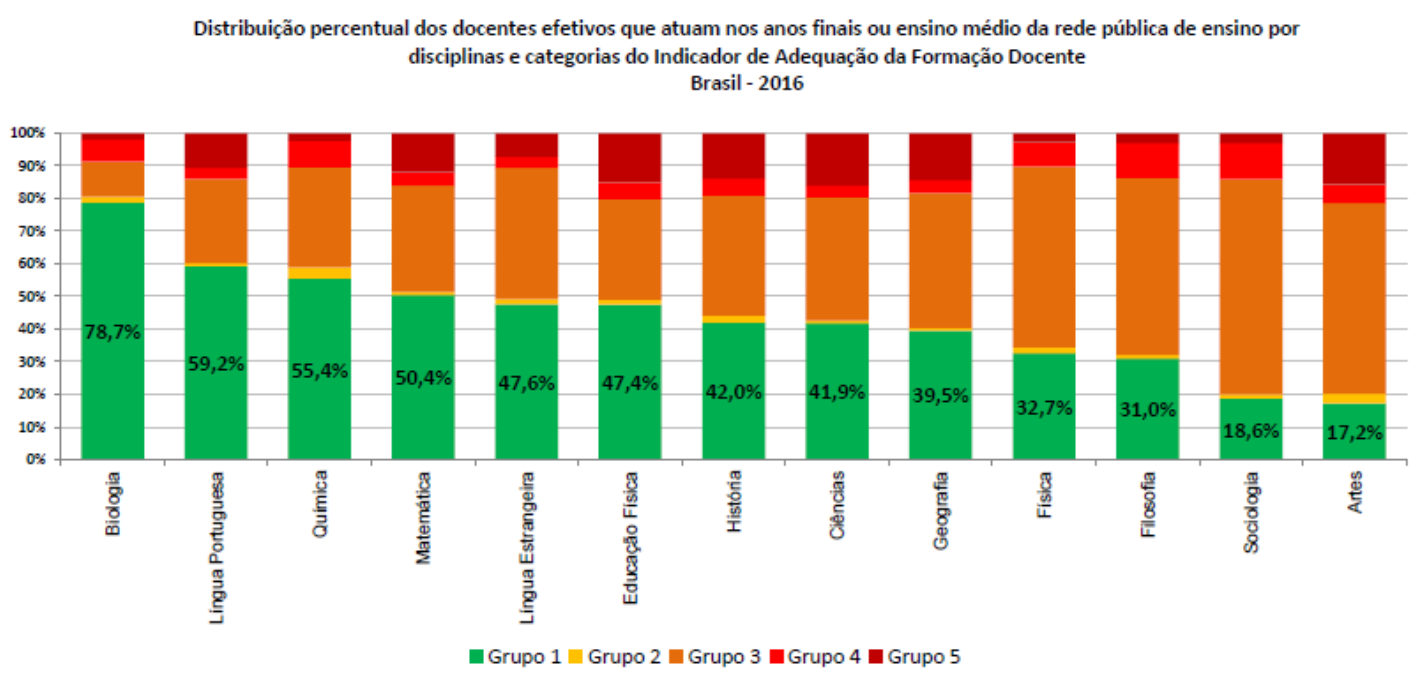

(4) iner ant

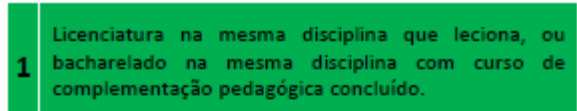
complementação pedagógica concluído.

Bacharelado na disciplina correspondente, mas sem

2 licenciatura ou complementação pedagógica.

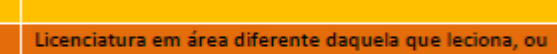

3 bacharelado nas disciplinas da base curricular comum e complementação pedagógica concluída em área diferente daquela que leciona.

Outra formação superior näo considerada nas categorias anteriores.

Nä́o possui curso superior completo.

Figura 4: Adequação da formação dos docentes da Educação Básica. Fonte: Censo da Educação Superior, 2016.

A inadequação da formação é um importante dado a ser refletido, visto que apenas quatro das treze disciplinas apresentam ao menos metade de seus professores com formação plena, apontando que os problemas na formação de professores começam ainda na base, na formação específica, e se desdobram nas questões didático pedagógicas. O domínio dos conhecimentos previstos na BNCC é destacado como um dos princípios da nova política, como já destacado em outros documentos oficiais anteriormente apresentados, que se encontra alinhado ao princípio que preconiza maior articulação entre teoria e prática.

Para além disso, é apresentada como política de formação a Base Nacional de Formação Docente, que tem como objetivo nortear o currículo da formação de 
professores e cuja proposta está em elaboração ${ }^{11}$ e deverá ser articulada com os entes federativos, instituições formadoras e o Conselho Nacional de Educação. Apesar da previsão de uma consulta pública a ser realizada no início de 2018 , nenhum documento foi anunciado oficialmente e nenhuma consulta foi realizada. O documento oficial vigente que apresenta orientações acerca da estrutura curricular da formação inicial docente é a Resolução $\mathrm{N}^{\mathrm{o}} 2$, de $1^{\circ}$ de julho de 2015 que define as Diretrizes Curriculares Nacionais para a formação inicial em nível superior (cursos de licenciatura, cursos de formação pedagógica para graduados e cursos de segunda licenciatura) e para a formação continuada. Em seu capítulo II dispõe sobre a base comum nacional para a formação dos profissionais do magistério para a educação básica que tem por objetivo conduzir o egresso da formação inicial "à práxis como expressão da articulação entre teoria e prática" e no que tange às TIC, subsidiar seu "uso competente para o aprimoramento da prática pedagógica e a ampliação da formação cultural dos(das) professores(as) e estudantes" (Art.5, VI). É ainda esperado, que o egresso componha um repertório de habilidades plural que inclua o planejamento e execução de atividades em espaços formativos virtuais, sugerindo também a composição de modelos híbridos (Art.7, III) e o "desenvolvimento, execução, acompanhamento e avaliação de projetos educacionais, incluindo o uso de tecnologias educacionais e diferentes recursos e estratégias didático-pedagógicas" (Art.7, VIII); o egresso, portanto, deve estar apto a "relacionar a linguagem dos meios de comunicação à educação, nos processos didático-pedagógicos, demonstrando domínio das tecnologias de informação e comunicação para o desenvolvimento da aprendizagem" (Art.8, V). O documento não faz menção específica às TIC como componente curricular ou mesmo como conteúdo. Gatti (2018) antecipa que a Base Nacional Docente exigirá que as licenciaturas não sejam apenas um complemento ao bacharelado, estabelecendo um projeto político e pedagógico próprio no qual se preveja a reserva de no mínimo $20 \%$ da grade curricular para a formação pedagógica assim como

\footnotetext{
11 O único documento disponível sobre a Base Nacional de Formação Docente é uma versão preliminar divulgada em fevereiro de 2016 pela comissão responsável por sua elaboração, coordenada pela professora Bernadete Gatti, intitulada "Orientações para cursos de Formação de Professores nas áreas de Didática, Metodologias e Práticas de Ensino". Trata-se de uma proposta pautada na observância de que a formação de professores para a Educação Básica "precisa falar com a sala de aula das escolas" e, no que se refere à relação educação-tecnologias, no pressuposto da Resolução CNE/CP 02/2015 que aponta para o "uso competente das Tecnologias de Informação e Comunicação (TIC) para o aprimoramento da prática pedagógica e a ampliação cultural dos(das) professores(as) e estudantes"(Inc.VI). Disponível em: https://avaliacaoeducacional.files.wordpress.com/2016/03/doc_formprof_didmetpe-6.pdf.
} 
todas as disciplinas componentes devem ser organizadas de forma a contemplar aspectos teóricos e práticos relativos à atividade docente. Três linhas de ação foram estipuladas para o incremento da formação inicial e representam a atualização de estratégias já em curso: a revitalização da Universidade Aberta do Brasil, que volta a oferecer cursos de primeira e segunda licenciatura na modalidade a distância; a ampliação do Programa Universidade para Todos (PROUNI) para graduados em serviço e para segunda licenciatura e o Programa de Residência Pedagógica, apresentado como a modernização do Programa Institucional de Bolsas de Iniciação à Docência (PIBID), que visa ao "aperfeiçoamento do estágio curricular supervisionado nos cursos de licenciatura, promovendo a imersão do licenciando na escola de educação básica, a partir da segunda metade de seu curso “ e inclui a "regência de sala de aula e intervenção pedagógica, acompanhadas por um professor da escola com experiência na área de ensino do licenciando e orientada por um docente da sua Instituição Formadora". ${ }^{12}$

\subsection{A Tecnologia no Currículo da Formação Inicial de Professores}

Foram analisados os currículos dos cursos de licenciatura oferecidos na modalidade presencial pelas três instituições investigadas, PUC Rio, UERJ (Campus Maracanã) e UFRJ (Todos os campi localizados na cidade do Rio de Janeiro) de acordo com os seguintes critérios de busca e seleção: (i) grades curriculares e ementas de disciplinas disponíveis online no site oficial da instituição; (ii) disciplinas oferecidas pelos Departamentos de Educação ou pelos departamentos específicos dos cursos de licenciatura; (iii) disciplinas que apresentam em seu título e/ou ementa indicação de que abordam aspectos relacionados a discussão e/ou aplicação da relação educação-tecnologias. No quadro 1 estão dispostas as informações relativas as vinte e cinco (25) disciplinas encontradas por meio da busca orientada pelos critérios acima mencionados. A distribuição das disciplinas por instituição se dá da seguinte forma: duas (2) são oferecidas pela PUC Rio, nove (9) pela UERJ e catorze (14) pela UFRJ. São ofertadas, no total doze (12) disciplinas obrigatórias (2 na PUC, 5 na UERJ e 5 na UFRJ) e treze (13) disciplinas eletivas (4 na UERJ e 9 na UFRJ). Além dos Departamentos de Educação, que oferecem disciplinas, obrigatórias e eletivas, para

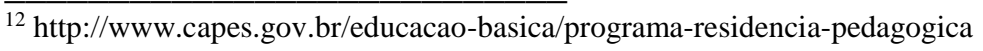


o curso de Pedagogia, e disciplinas eletivas para todas as demais licenciaturas, os Departamentos de Letras, Ciências Sociais, Educação Física, Educação Artística, Física, Matemática, Biologia e Geografia, aparecem como outros espaços de oferta de disciplinas para os cursos de licenciatura que tem a relação entre educação e tecnologias digitais e/ou a informática na educação como temas centrais em sua constituição.

\begin{tabular}{|c|c|c|c|c|}
\hline INSTITUIÇÃO & CURSO & DISCIPLINA & TIPO & PERÍODO \\
\hline PUC RIO & Pedagogia & Mídia, Tecnologias e Educação & Obrigatória & $1^{\circ}$ \\
\hline PUC RIO & Letras & Oficina 2-Tecnologia, Ensino e Aprendizagem de Língua Materna & Obrigatória & $3^{\circ}$ \\
\hline UERJ & Pedagogia & Tecnologias e Educação & Obrigatória & $1^{\circ}$ \\
\hline UERJ & Pedagogia & Pesquisa e Prática Pedagógica - EaD & Obrigatória & $3^{\circ}$ ao $6^{\circ}$ \\
\hline UERJ & Pedagogia & Monografia em Educação - EaD & Obrigatória & $7^{\circ}$ e $8^{\circ}$ \\
\hline UERJ & Licenciaturas & Avaliação de Software Educativo & Eletiva & ND \\
\hline UERJ & Licenciaturas & Educação a Distância & Eletiva & ND \\
\hline UERJ & Ciênciais Sociais & Prat Pedag Ciências Sociais II: Tec Ped, Dinâmicas e Utilização Rec Audiovisuais & Obrigatória & $6^{\circ}$ \\
\hline UERJ & Educação Física & Iniciação à Informática Aplicada à Pesquisa em Educação Física & Obrigatória & $1^{\circ}$ \\
\hline UERJ & Letras & Técnicas de Pesquisa de Fontes Bibliográficas e Virtuais & Eletiva & ND \\
\hline UERJ & Letras - Inglês & Prática de Ensino em Língua Inglesa I: O Uso da Tecnologia & Eletiva & ND \\
\hline UFRJ & Pedagogia & Informática Aplicada à Educação & Obrigatória & $2^{\circ}$ \\
\hline UFRJ & Pedagogia & Educação a Distância & Eletiva & ND \\
\hline UFRJ & Pedagogia & Educação e Novas Tecnologias & Eletiva & ND \\
\hline UFRJ & Pedagogia & Oficina de Multimeios & Eletiva & ND \\
\hline UFRJ & Pedagogia & Informática no Processo Ensino-Aprendizagem & Eletiva & ND \\
\hline UFRJ & Pedagogia & Tratamento Informático de Dados em Educação & Eletiva & ND \\
\hline UFRJ & Ciências Sociais & Laboratório de Pesquisa Audiovisual & Obrigatória & $6^{\circ}$ \\
\hline UFRJ & Educação Artística & Teoria da Informação e da Comunicação & Obrigatória & $1^{\circ}$ \\
\hline UFRJ & Física & Informática no Ensino de Ciências & Obrigatória & $5^{\circ}$ \\
\hline UFRJ & Matemática & Informática Aplicada ao Ensino de Matemática & Obrigatória & $5^{\circ}$ \\
\hline UFRJ & Bilologia & Informática Aplicada ao Ensino de Biologia & Eletiva & ND \\
\hline UFRJ & Geografia & Tecnologia da Informação e Ciberespaço & Eletiva & ND \\
\hline UFRJ & Geografia & Introdução a Novas Tecnologias no Ensino de Geografia & Eletiva & ND \\
\hline UFRJ & Geografia & Aplicação de Novas Tecnologias no Ensino de Geografia & Eletiva & ND \\
\hline
\end{tabular}

Quadro 1: Disciplinas TIC nos cursos de licenciatura da PUC Rio, UERJ e UFRJ. Fonte: autoria própria, a partir das grades curriculares e ementas disponíveis nos sites das instituições.

Após a ordenação das disciplinas de acordo com os critérios dispostos no quadro acima, procedeu-se a leitura e análise de suas ementas, de onde se depreendeu dois eixos norteadores e suas respectivas categorias de análise (Quadro 2). No primeiro eixo foram alocados os conteúdos disciplinares de abordagem teórica segundo três categorias: (i) Fundamentação, (ii) Políticas e Legislação e (iii) Recursos. No segundo eixo foram alocados os conteúdos disciplinares de abordagem prática/aplicada segundo cinco categorias: (i) Instrumental, (ii) Produção, (iii) Avaliação, (iv) Curadoria e (v) Mediação. Na abordagem teórica destacam-se três temas de fundamentação que contribuem para a discussão sobre o aporte teórico de uma perspectiva de aprendizagem híbrida e adaptativa, são eles: aprendizagem colaborativa; novos modelos de ensino-aprendizagem com TIC; teorias de aprendizagem, abordagens de ensino e TIC. 


\begin{tabular}{|c|c|}
\hline ABORDAGEM TEÓRICA & TEMAS ABORDADOS \\
\hline Fundamentação & $\begin{array}{l}\text { - Alfabetização midiática e informacional; } \\
\text { - Aprendizagem colaborativa; } \\
\text { - } \quad \text { Cibanços científicos e inovação; } \\
\text { - } \text { Ciberespaço; } \\
\text { - } \quad \text { Eigital; } \\
\text { - Elem; } \\
\text { - Ética; } \\
\text { - } \text { Habilidades para produção do conhecimento; } \\
\text { - } \quad \text { Novos modelos de ensino-aprendizagem com TIC; } \\
\text { - Pesquisas e experiências; } \\
\text { - Teolícas públicas; } \\
\text { - TIC e Projeto Político Pedagógico (PPP); } \\
\text { Virtual; }\end{array}$ \\
\hline Políticas e Legislação & $\begin{array}{ll} & \text { EaD; } \\
\text { - } & \text { Formação de Professores } \\
\text { - } & \text { LDB; } \\
\text { - } & \text { TIC e Educação. }\end{array}$ \\
\hline Recursos & $\begin{array}{ll}\text { - } & \text { Aplicativos; } \\
\text { - } & \text { AVA; } \\
\text { - } & \text { Bibliotecas; } \\
\text { - } & \text { Internet; } \\
\text { - } & \text { Linguagem LOGO; } \\
\text { - } & \text { Mídias; } \\
\text { - } & \text { Porttimeios; } \\
\text { - } & \text { Softwares. } \\
\end{array}$ \\
\hline
\end{tabular}

Quadro 2: Abordagem teórica das disciplinas TIC. Fonte: autoria própria, a partir das ementas das disciplinas.

A articulação entre currículo e tecnologias aparece mais fortemente marcada no âmbito do debate sobre a legislação educacional e sua aplicabilidade, especialmente a Lei de Diretrizes e Bases da Educação (LDB) e os Parâmetros Curriculares Nacionais (PCN). Paulatinamente a abordagem sobre os PCN vêm sendo substituída pela análise e crítica da BNCC, como os dados apresentados na seção a seguir mostrarão. As políticas públicas para a educação a distância, educação tecnologia/informática educativa e de formação de professores são discutidas de forma articulada, buscando entrelaçamentos e implicações entre as mesmas. Quanto aos recursos tecnológicos disponíveis e seus meios de apropriação didático-metodológica, se destaca o debate acerca da internet, dos ambientes virtuais de aprendizagem, dos repositórios de objetos de aprendizagem (bibliotecas e portais educativos) e recursos digitais (mídias, aplicativos, multimeios e 
softwares). O aporte teórico sobre programação aparece nos cursos de informática aplicada ao ensino de ciências e biologia, com destaque para a discussão sobre o uso da linguagem LOGO, desenvolvida por Seymour Papert para iniciar crianças no universo da programação de computadores, propondo a utilização da tecnologia a partir de uma perspectiva construtivista.

\begin{tabular}{|c|c|}
\hline ABORDAGEM PRÁTICA & ATIVIDADES/HABILIDADES DESENVOLVIDAS \\
\hline Instrumental & $\begin{array}{ll}\text { - } & \text { Audiovisual; } \\
\text { - } & \text { AVA; } \\
\text { - } & \text { Internet; } \\
\text { - } & \text { LOGO; } \\
\text { - } & \text { Material multimídia; } \\
\text { - } & \text { Pacote Office; } \\
\text { - } & \text { Software educativo; } \\
\text { - } & \text { Softwares e hardwares específicos da área disciplinar. }\end{array}$ \\
\hline Produção & $\begin{array}{ll}\text { - } & \text { Atlas Digitais; } \\
\text { - } & \text { Audiovisual; } \\
\text { - } & \text { Elaboração de textos didáticos; } \\
\text { - } & \text { Material didático; } \\
\text { - } & \text { Material multimídia; } \\
\text { - } & \text { Modelagem; } \\
\text { - } & \text { Multimeios; } \\
\text { - } & \text { Planejamento e gerência de projetos EaD; } \\
\text { - } & \text { Planos de Aula; } \\
\text { - } & \text { Programação; } \\
\text { - } & \text { Simulações. }\end{array}$ \\
\hline Avaliação & $\begin{array}{ll}\text { - } & \text { AVA; } \\
\text { - } & \text { Material multimídia; } \\
\text { - } & \text { Software educativo. } \\
\end{array}$ \\
\hline Curadoria & $\begin{array}{ll}\text { - } & \text { Adaptação de textos acadêmicos; } \\
\text { - } & \text { Internet; } \\
\text { - } & \text { Material didático; } \\
\text { - } & \text { Multimeios; } \\
\text { - } & \text { Sistematização do conhecimento; } \\
\text { - } & \text { Técnicas de pesquisa; } \\
\text { - } & \text { Tratamento de dados educacionais. } \\
\end{array}$ \\
\hline Mediação & $\begin{array}{ll}\text { - } & \text { Aplicação LDB/PCN } \\
\text { - } & \text { Autoria; } \\
\text { - } & \text { Co-participação; } \\
\text { - } & \text { Desenho instrucional; } \\
\text { - } & \text { Estratégias para uso das TIC; } \\
\text { - } & \text { Pesquisa e avaliação de experiências; } \\
\text { - } & \text { Tutoria. }\end{array}$ \\
\hline
\end{tabular}

Quadro 3: Abordagem prática das disciplinas TIC. Fonte: autoria própria, a partir das ementas das disciplinas.

$\mathrm{Na}$ abordagem prática/aplicada, AVA e softwares educativos aparecem nas dimensões instrumental, relativa à preparação para o uso de ferramentas tecnológicas e também na dimensão de avaliação, na qual os futuros professores são estimulados (re)elaborar critérios avaliativos para que as ferramentas sejam 
classificadas não somente sob requisitos técnicos mas também pedagógicos. $\mathrm{Na}$ dimensão de produção, a criação de mídias e objetos de aprendizagem é predominante, mas divide espaço com a gestão de ambientes de aprendizagem e a programação de computadores. A partir do exposto nas ementas analisadas. é possível perceber um movimento em direção a uma formação inicial de professores que contempla as dimensões da curadoria, design e orientação como elementos constituintes do fazer docente. O princípio da curadoria se estabelece como norteador para (i) utilizar a internet de maneira eficiente, selecionando os melhores recursos e conteúdos para compor situações didáticas, (ii) utilizar ferramentas de busca para pesquisas acadêmicas que permitam analisar dados educacionais ou que consubstanciem os processos de transposição didática. A mediação está ancorada no pressuposto da autoria e do design, onde o professor, após curar conteúdos e recursos, pode assumir o desenho didático de aulas e cursos, atuando como tutor/orientador no processo de aprendizagem de seus alunos, em uma perspectiva colaborativa.

\subsection{Percepções de Professores Formadores Sobre as Tecnologias Digitais na Formação Inicial Docente}

Muito se discute a inserção, uso e incorporação das tecnologias nas escolas (Andrade, 2013), as dificuldades, principalmente em termos de infraestrutura, e uma persistente resistência dos professores para que esta integração se efetive, muitas vezes atrelada à lacunas na sua formação. Dados da pesquisa TIC Educação (CETIC.BR, 2016) apontam que apenas $43 \%$ dos professores respondentes tiveram alguma disciplina específica na graduação/licenciatura sobre como usar computador e internet em atividades com alunos e que $91 \%$ buscam atualização quanto ao uso de computador e internet sozinhos, contra apenas $21 \%$ que afirmaram ter recebido formação em serviço através das secretarias de educação. Este cenário indicou a necessidade de melhor compreender como tem sido a formação inicial docente especificamente no que concerne a incorporação das tecnologias digitais na prática docente daqueles que formam os futuros professores da Educação Básica. Os 31 respondentes desta pesquisa lecionam em universidades da cidade do Rio de Janeiro (PUC Rio, UERJ e UFRJ), atuando nos cursos de pedagogia, e nas licenciaturas. 
Entre os 21 professores que afirmaram usar as tecnologias em aulas de disciplinas que não tem as TIC como sua temática central, destaca-se a utilização no curso de Pedagogia e na disciplina de Didática (Geral ou Específica). Este resultado reforça a importância da disciplina de Didática nas licenciaturas como o principal espaço para discussão das práticas pedagógicas e métodos de ensino, incluindo aquelas(es) mediadas(os) pelas tecnologias.

As respostas à pergunta "Como é feita esta integração das TIC em sala de aula?" foram analisadas a partir de categorias temáticas que emergiram das falas dos professores sobre seu modus operandi apoiado por tecnologias digitais. Dez categorias de análise foram identificadas: Suporte Tecnológico, Recurso Didático, Metodologia de Pesquisa, Curadoria de Conteúdos, Comunicação, Análise de Desempenho, Conteúdo, Autoria, Cooperação e Colaboração, Avaliação, Abordagem Híbrida. O quadro 3 apresenta o uso atual das tecnologias e as perspectivas de uso futuras. $\mathrm{O}$ uso como suporte, para projeção de conteúdo, aparece em boa parte das falas e inicialmente poderia apontar para um uso conservador da tecnologia, como mera transposição técnica sem a preocupação com a transposição didática, porém muitos professores indicam o uso dos celulares dos alunos, que para além de servir como suporte tecnológico, demanda uma postura mais ativa e autônoma. De acordo com os últimos relatórios do New Media Consortium (2017) que examinam tecnologias emergentes pelo seu potencial de impacto no ensino, aprendizado e investigação criativa nas escolas e universidades, a aprendizagem móvel que enseja a ideia de que cada um se utilize do seu dispositivo móvel para a aprendizagem (Bring Your Own Device - BYOD) deixou o horizonte de emergência e se estabeleceu como realidade. 


\begin{tabular}{|c|c|c|}
\hline Categorias de Uso das TIC & Uso Atual & Perspectivas de Uso \\
\hline Suporte Tecnológico & $\begin{array}{l}\text { Apoio a apresentações; Mostrar coisas; Projetores com } \\
\text { computadores; Celulares dos alunos (pesquisas, consultas, } \\
\text { leitura de textos); Internet móvel; Bluetooth }\end{array}$ & Mobile Learning; BYOD \\
\hline Recurso Didático & $\begin{array}{l}\text { Ferramentas/softwares de disciplina específica; editores } \\
\text { multimídias; mídias (imagens, vídeos, áudios) }\end{array}$ & Realidade Aumentada; Laboratórios Virtuais \\
\hline Metodologia de Pesquisa & $\begin{array}{l}\text { Motores de busca (Google, Youtube); Pesquisa em aula; Base } \\
\text { de dados; Pesquisa de inspiração etnográfica }\end{array}$ & Big Data e Data Mining \\
\hline Curadoria de Conteúdos & $\begin{array}{l}\text { Consulta a páginas/informações; Seleção de materiais } \\
\text { didáticos; Dados oficiais }\end{array}$ & Big Data e Data Mining \\
\hline Comunicação & Síncrona e assíncrona (e-mail, Whatsapp); Redes sociais & Mobile Learning \\
\hline Análise de Desempenho & Análise de boletins escolares & Learning Analytics \\
\hline Conteúdo & $\begin{array}{l}\text { Específico da disciplina; Análise de prática pedagógica; Foco } \\
\text { de estudo em atividades }\end{array}$ & $\begin{array}{l}\text { Pensamento Computacional, Robótica, } \\
\text { Makerspaces }\end{array}$ \\
\hline Autoria e Colaboração & $\begin{array}{l}\text { Ferramentas de autoria (co autoria) e colaborativas (Google } \\
\text { Drive); Editores multimídia (criação de vídeos); tirar dúvidas; } \\
\text { Lista de discussão }\end{array}$ & Internacionalização; Cooperação; Colaboração \\
\hline Avaliação & Realização e/ou envio de tarefas e trabalhos & $\begin{array}{l}\text { Learning Analytics, Aprendizagem } \\
\text { Adaptativa/Personalizada }\end{array}$ \\
\hline Abordagem Híbrida & $\begin{array}{l}\text { Por meio de AVA, Rede Social ou Ferramenta de Comunicação } \\
\text { Síncrona; Apresentar conceitos de maneira mais objetiva; } \\
\text { Incorporação à prática de ensino/docente; Criar possibilidade } \\
\text { de formar senso crítico; Aulas tecnologizadas; Dinamização da } \\
\text { aula, com uso multifuncional das TIC }\end{array}$ & Aprendizagem Adaptativa/Personalizada \\
\hline
\end{tabular}

Quadro 4: Uso atual e perspectiva de uso das TIC na formação inicial docente.

Esta constatação exige uma ponderação, por um lado, são inúmeras as possibilidades facultadas por esta tecnologia, em especial a conectividade, que permite seu uso como recurso didático, conteúdo e para fins de pesquisa; por outro lado suscita o debate sobre acessibilidade e equidade, visto que mesmo com a disseminação dos smartphones nem todos ainda dispõem desta tecnologia. A combinação do espaço físico da universidade com ambientes virtuais para a realização de atividades acadêmicas e comunicação síncrona e assíncrona indica uma predisposição à adoção de modelos híbridos de aprendizagem e a percepção de que o mesmo é resultado da apropriação e incorporação das tecnologias digitais à prática docente, tal como inscrito na concepção de engajamento digital preconizada por Gourlay (2017). O uso de tecnologias para fins de avaliação é conservador: realização e envio de trabalhos, demonstrando que a aprendizagem adaptativa, potencialmente viabilizada pelas tecnologias, ainda não se configura como opção para avaliar os alunos e reorientar a prática docente através da análise da aprendizagem (learning analytics).

Ao discutir a composição de um perfil docente que contemple a curadoria que aparece nas respostas através da indicação do uso das TIC para seleção de conteúdos, materiais didáticos e pesquisas em ferramentas de busca e repositórios -, como uma das atividades inerentes à profissão, é importante resgatar a etimologia da palavra. "O ato de 'curar' está relacionado com o zelo, cuidado e atenção com 
alguma coisa"13. Ser um professor curador, portanto, implica cuidar, selecionar e distribuir informação/conteúdo de maneira adequada ao aluno, de acordo com critérios como objetivos de aprendizagem, intencionalidade pedagógica e perfil cognitivo dos aprendizes. A curadoria, quando incorporada à prática docente $\mathrm{e}$ como objetivo de aprendizagem, estimula a criatividade e a criticidade, elementos importantes para o desenvolvimento cognitivo e formação cidadã. A vantagem da adoção desta prática mediada pelas tecnologias aparece na fala dos respondentes, onde a pesquisa e seleção de informação contribui para a promoção do senso crítico. A BNCC do Ensino Médio por sua vez, especialmente na área de linguagens, define e apresenta a curadoria, em termos de sua relação com a pesquisa e como competência a ser desenvolvida apoiada pelas tecnologias digitais:

"A curadoria de informação envolve processos mais apurados de seleção e filtragem de informações, o que pode requerer procedimentos de checagem e validação, comparações, análises etc. Pode envolver também organização, categorização e reedição de informações." (BNCC, 2017, p.492)

"Em que pese o potencial participativo e colaborativo das TDIC, a abundância de informações e produções requer, ainda, que os estudantes desenvolvam habilidades e critérios de curadoria e de apreciação ética e estética, considerando, por exemplo, a profusão de notícias falsas (fake news), de pós-verdades e de discursos de ódio nas mais variadas instâncias da internet e demais mídias”. (BNCC, 2017, p.479)

"Para tanto, é necessário não somente possibilitar aos estudantes explorar interfaces técnicas (como a das linguagens de programação ou de uso de ferramentas e apps variados de edição de áudio, vídeo, imagens, de realidade aumentada, de criação de games, gifs, memes, infográficos etc.), mas também interfaces éticas que lhes permitam tanto triar e curar informações como produzir o novo com base no existente." (BNCC, 2017, p.489)

“A pesquisa, por exemplo, além de ser mais diretamente dedicada a um campo, perpassa todos os outros em ações de busca, seleção, validação, tratamento e organização de informação envolvidas na curadoria de informação, devendo também estar presente no tratamento metodológico dos conteúdos" (BNCC, 2017, p.497)

Seja na forma de habilidades a serem desenvolvidas como na BNCC, seja sob a forma de eixos cognitivos como proposto pela Matriz de Referência do Exame Nacional do Ensino Médio (ENEM) ${ }^{14}$, a curadoria aparece como elemento importante, mobilizador de diferentes aprendizagens:

\footnotetext{
$\overline{13}$ https://www.significados.com.br/curadoria/

${ }^{14}$ Matriz de Referência do ENEM.
http://download.inep.gov.br/educacao_basica/enem/downloads/2012/matriz_referencia_enem.pdf
} 
"Fazer curadoria de informações, tendo em vista diferentes propósitos e projetos discursivos."

"Analisar os processos humanos e automáticos de curadoria que operam nas redes sociais e outros domínios da internet, comparando os feeds de diferentes páginas de redes sociais e discutindo os efeitos desses modelos de curadoria, de forma a ampliar as possibilidades de trato com o diferente e minimizar o efeito bolha e a manipulação de terceiros." "Acompanhar, analisar e discutir a cobertura da mídia diante de acontecimentos e questões de relevância social, local e global, comparando diferentes enfoques e perspectivas, por meio do uso de ferramentas de curadoria de informação (como agregadores de conteúdo) e da consulta a serviços e fontes de checagem e curadoria de informação, de forma a aprofundar o entendimento sobre um determinado fato ou questão, identificar o enfoque preponderante da mídia e manter-se implicado, de forma crítica, com os fatos e as questões que afetam a coletividade.” (BNCC, 2017, p. 499 e 512)

Enfrentar situações-problema: selecionar, organizar, relacionar, interpretar dados e informações representados de diferentes formas, para tomar decisões e enfrentar situações-problema.

Construir argumentação: relacionar informações, representadas em diferentes formas, e conhecimentos disponíveis em situações concretas, para construir argumentação consistente. (Matriz de Referência ENEM, p.1)

No que concerne ao uso das tecnologias digitais para fomentar processos de autoria, cooperação e colaboração, está imbricada a ideia de que as dimensões individual e coletiva da aprendizagem, estão cada vez mais entrelaçadas e podem ser potencializadas por toda a gama de recursos e possibilidades de conexão que a internet propicia.

\begin{tabular}{|c|c|c|c|c|}
\hline \multirow{2}{*}{$\begin{array}{l}\text { Recursos Digitais } \\
\text { Das ferramentas e aplicativos citados na sequência, } \\
\text { uso para o desenvolvimento de minha atividade } \\
\text { docente }\end{array}$} & \multicolumn{4}{|c|}{ Frequência de Uso } \\
\hline & Nunca & Pouco & Muito & Sempre \\
\hline $\begin{array}{l}\text { Comunicação (e-mail, fórum, chat, } \\
\text { videoconferência...) }\end{array}$ & 0 & 4 & 9 & 18 \\
\hline $\begin{array}{l}\text { Redes Sociais (Facebook, Twitter, Linkedin, } \\
\text { ResearchGate...) }\end{array}$ & 10 & 10 & 7 & 4 \\
\hline $\begin{array}{l}\text { Ferramentas de trabalho colaborativo (blogs, wikis, } \\
\text { GoogleDrive, OneDrive...) }\end{array}$ & 4 & 13 & 7 & 7 \\
\hline $\begin{array}{l}\text { Ambientes Virtuais de Aprendizagem (Learning } \\
\text { Management Systems) }\end{array}$ & 17 & 10 & 1 & 3 \\
\hline $\begin{array}{l}\text { Ferramentas de busca e publicação de informações } \\
\text { (Google, YouTube...) }\end{array}$ & 1 & 7 & 10 & 13 \\
\hline Editores de Texto & 2 & 4 & 7 & 18 \\
\hline $\begin{array}{l}\text { Editor Multimídia (gráficos, imagens, áudio, vídeos, } \\
\text { apresentações) }\end{array}$ & 2 & 7 & 11 & 11 \\
\hline
\end{tabular}

Tabela 1: Frequência de uso dos recursos digitais na formação inicial docente.

O uso dos recursos digitais mostra-se conservador, com a prevalência de utilização de ferramentas assíncronas (e-mails, editores de texto e multimídia) que 
remontam a Web 1.0, onde a revolução digital provocada pelo advento da internet se iniciava. Os recursos de edição aliados ao crescimento da utilização de motores de busca pode contribuir para a incorporação da curadoria à prática docente e promoção de um uso mais inovador e colaborativo das tecnologias. As ferramentas colaborativas, que inauguraram a era social da internet, a Web 2.0, são subutilizadas de acordo com os dados e revelam que, mesmo já inseridos na era da Web Semântica ou Web 3.0, onde a ideia de personalização está ensejada, em termos de formação docente ainda é necessário se apropriar, através do emprego constante, da lógica de criação-produção-colaboração que constitui as ferramentas Web 2.0. É importante ressaltar que a caracterização dos diferentes momentos da internet não significa o desaparecimento de um conjunto de ferramentas que passa a ser substituído por outro, pois os recursos surgidos em cada uma das eras supracitadas passam a conviver de forma conjugada. As mudanças mencionadas são mais que tecnológicas, são fruto das novas formas de utilização e interação que nós, enquanto usuários, estabelecemos com a internet.

\begin{tabular}{|c|c|c|c|c|}
\hline \multirow{2}{*}{$\begin{array}{l}\text { Fatores Condicionantes para o Uso das TIC } \\
\text { No momento de escolher um recurso TIC } \\
\text { para usar em aula, a importância que dou } \\
\text { aos seguintes fatores é: }\end{array}$} & \multicolumn{4}{|c|}{ Grau de Importância } \\
\hline & $\begin{array}{c}\text { Nada } \\
\text { Importante }\end{array}$ & $\begin{array}{c}\text { Pouco } \\
\text { Importante }\end{array}$ & Importante & $\begin{array}{c}\text { Muito } \\
\text { Importante }\end{array}$ \\
\hline Facilidade de uso & 0 & 1 & 9 & 21 \\
\hline Relevância científica e profissional & 1 & 4 & 16 & 10 \\
\hline Inovação tecnológica e didática & 1 & 6 & 17 & 7 \\
\hline Se resolve necessidades de aprendizagem & 0 & 1 & 16 & 14 \\
\hline $\begin{array}{l}\text { Acessibilidade (que pode ser usado por } \\
\text { todos os alunos, inclusive pessoas com } \\
\text { deficiência) }\end{array}$ & 0 & 3 & 11 & 17 \\
\hline $\begin{array}{l}\text { Facilidade de acesso para todos os alunos } \\
\text { (independente de sua situação } \\
\text { socioeconômica) }\end{array}$ & 0 & 1 & 8 & 22 \\
\hline $\begin{array}{l}\text { Tempo de dedicação (preparação para } \\
\text { utilização do recurso e logística para } \\
\text { utilização em aula) }\end{array}$ & 0 & 4 & 13 & 14 \\
\hline Recurso motivador para os alunos & 0 & 0 & 10 & 21 \\
\hline
\end{tabular}

Tabela 2: Fatores condicionantes para o uso das TIC na formação inicial docente.

Os dados nos revelam que, tal como nos reportam diferentes modelos de aceitação das tecnologias (Brás et al., 2014; Teo 2009), os fatores mais relevantes na seleção e adoção de recursos digitais pelos professores são a facilidade de uso e a utilidade proporcionada, este último indicado pelas variáveis "Se resolve 
necessidades de aprendizagem" e "Recurso motivador para os alunos", percepcionadas pelos respondentes como mais importantes no momento de escolha das tecnologias a serem empregadas em sua atividade docente. Todos os fatores elencados se mostraram, pela distribuição das respostas majoritariamente entre "importante" e "muito importante", critérios complementares na seleção de recursos digitais. O uso destes recursos como possibilidade de inovação didáticotecnológica indica a percepção dos professores sobre o impacto positivo que o uso da tecnologia pode ter no exercício da docência e no processo de aprendizagem dos alunos, demonstrando alinhamento com os pressupostos de abordagens educativas emergentes, tais como a aprendizagem híbrida e adaptativa. Chama a atenção a percepção de que a tecnologia precisa ser incorporada pelo viés da emancipação, garantindo equidade ao acesso à educação medida por tecnologias digitais.

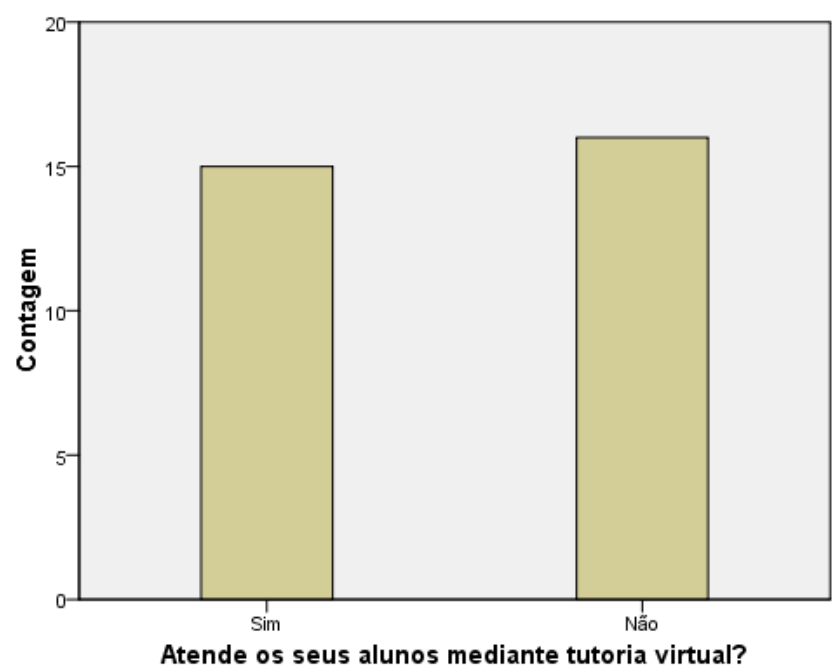

Figura 5: Realização de tutoria virtual na formação inicial docente. 


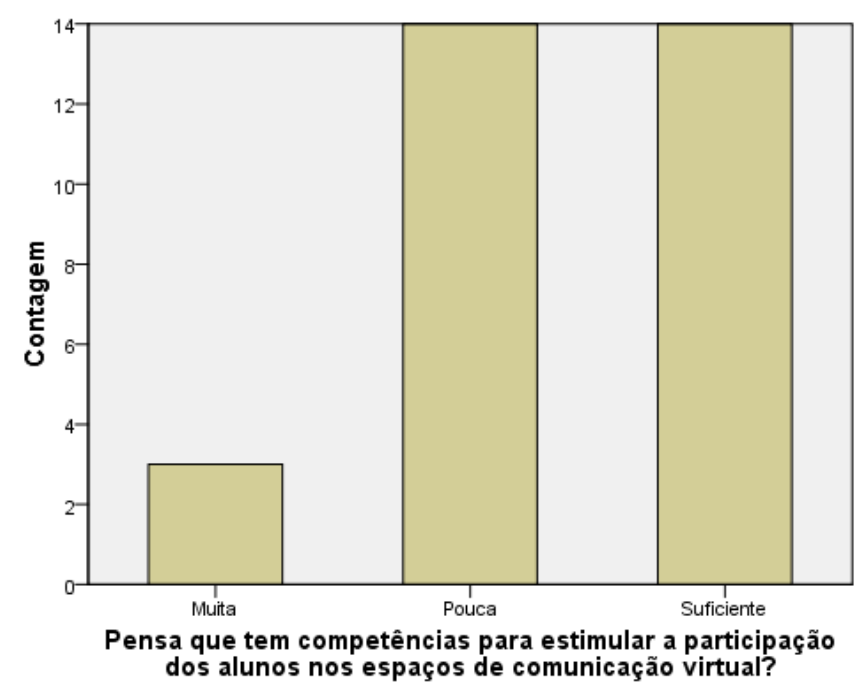

Figura 6: Percepção sobre confiança na mediação em espaços virtuais.

No que se refere a mediação em ambientes virtuais, os dados sugerem que o nível de confiança que os professores percepcionam ter para estimular a participação online está relacionado à adoção da tutoria virtual. Brás et al. (2014) reportam que a dicotomia entre as habilidades tecnológicas e fluência digital de professores e alunos é um fator concorrente para que os professores evitem o uso das tecnologias, por se sentirem forçados a sair de sua zona de conforto, sem a segurança e sensação de domínio necessárias para incorporação das TIC no processo de mediação pedagógica. Em uma fala, que será reproduzida no quadro 6, sobre os limites e possibilidades das TIC na Educação, um respondente declara que os limites são seus e não das tecnologias, o que reforça a importância de uma formação sólida não somente em tecnologias, mas que seja pautada na aplicação prática dos conhecimentos e habilidades desenvolvidos na formação inicial, promovendo assim uma inquietação necessária ao fazer docente.

No quadro 5, uma síntese acerca do uso das tecnologias digitais no processo de avaliação dos alunos, por tipo de avaliação. Nota-se ausência do uso de tecnologias, como por exemplo plataformas adaptativas, para realização de avaliação diagnóstica. A tecnologia porém, é utilizada para potencializar a avaliação mediadora, que pressupõe interatividade e acompanhamento contínuo. 


\begin{tabular}{|c|c|c|}
\hline Tipos de Avaliação & Conceito & Uso das TIC na Avaliação \\
\hline Somativa & $\begin{array}{l}\text { "A avaliação somativa é uma avaliação muito } \\
\text { geral, que serve como ponto de apoio para atribuir } \\
\text { notas, classificar o aluno e transmitir os resultados } \\
\text { em termos quantitativos, feita no final de um } \\
\text { período". (BLOOM; HASTINGS; MADAUS, 1983, p. } \\
\text { 100). }\end{array}$ & $\begin{array}{l}\text { Recebimento de trabalhos por meio de ferramentas de comunicação } \\
\text { digitais }\end{array}$ \\
\hline Diagnóstica & $\begin{array}{l}\text { “A avaliação diagnóstica possibilita ao educador e } \\
\text { educando detectarem, ao longo do processo de } \\
\text { aprendizagem, suas falhas, desvios, suas } \\
\text { dificuldades, a tempo de redirecionarem os meios, os } \\
\text { recursos, as estratégias e procedimentos na direção } \\
\text { desejada” (MACHADO, 1995, p. 33) }\end{array}$ & $\begin{array}{l}\text { Esta definição de avaliação diganóstica se aproxima muito da definição de } \\
\text { avaliação formativa e, portanto, o uso das TIC pode ser identificado de } \\
\text { forma idêntica. Porém, se tomarmos como definição de avaliação } \\
\text { diagnóstica aquela que é realizada como ponto de partida para iniciar um } \\
\text { processo de aprendizagem orientado pelo reconhecimento de níveis de } \\
\text { desenvolvimentos já atingidos, o uso das TIC para a realização de } \\
\text { avaliações nesse sentido não foi identificado nas respostas. }\end{array}$ \\
\hline Formativa & $\begin{array}{l}\text { "Uma avaliação formativa (...) dá informaç̃̃es, } \\
\text { identifica erros, sugere interpretações quanto às } \\
\text { estratégias e atitudes dos alunos e, portanto, } \\
\text { alimenta diretamente a ação pedagógica" } \\
\text { (PERRENOUD, 2008, p. 68). }\end{array}$ & $\begin{array}{l}\text { Uso do recurso comentário disponível em editores de texto; Portfólios; } \\
\text { Edição de vídeos; Chat; Fórum; Wiki; Interface entre diferentes suportes } \\
\text { tesxtuais e informacionais; Trabalhos de Conclusão de Curso entregues em } \\
\text { formato alternativo, tais como artigo científico, relato de experiência, } \\
\text { memorial de formação, proposta de material didático ou atividade lúdica, } \\
\text { apresentação de performances e organização de curtas, documentários ou } \\
\text { vídeos com conteúdos ligados à uma proposta de educativa ou de } \\
\text { formação humana. }\end{array}$ \\
\hline Mediadora & $\begin{array}{l}\text { "Ação avaliativa como uma das mediaç̃̃es pela qual } \\
\text { se encorajaria a reorganização do saber. Ação, } \\
\text { movimento, provocação, na tentativa de } \\
\text { reciprocidade intelectual entre os elementos da ação } \\
\text { educativa. Professor e aluno buscando coordenar } \\
\text { seus pontos de vista, trocando idéias, reorganizando- } \\
\text { as". (HOFFMANN, 1991, p. 67) }\end{array}$ & $\begin{array}{l}\text { Uso do recurso comentário disponível em editores de texto; Análise de } \\
\text { postagens dos alunos na interação online gera feedback na interação } \\
\text { presencial ; Uso de ferramentas de comunicação digitais para tirar dúvidas } \\
\text { e enviar feedback }\end{array}$ \\
\hline
\end{tabular}

Quadro 5: Uso das tecnologias por tipo de avaliação na formação inicial docente. ${ }^{15}$

Quanto ao uso de abordagens educativas emergentes, os dados revelam um descompasso entre o que é ofertado na formação inicial docente e as demandas da Educação Básica, onde os futuros professores atuarão. Segundo o relatório do New Media Consortium para a Educação Básica (2015), a aprendizagem híbrida já se apresentava como tendência para adoção em curto prazo; vale ressaltar que, mesmo não identificando de forma literal a adoção de modelos híbridos, ao descrever o uso que fazem das tecnologias em aula, os professores elencam para além da utilização de AVA, da metodologia de sala de aula invertida, redes sociais e ferramentas de comunicação síncronas como parte de suas estratégias docentes, o que já configuraria uma aproximação de uma abordagem híbrida. A aprendizagem adaptativa, que pode se utilizar de estratégias gamificadas, possui uma tendência de adoção a médio prazo e ganha força com a ampliação da discussão sobre o uso das tecnologias digitais para a personalização da aprendizagem. 


\begin{tabular}{|l|c|c|}
\hline Já fez ou faz uso de alguma destas abordagens metodológicas? & SIM & NÃO \\
\hline Blended Learning (Aprendizagem Híbrida) & 2 & 28 \\
\hline Adaptive Learning (Aprendizagem Adaptativa) & 2 & 28 \\
\hline Flipped Classroom (Sala de Aula Invertida) & 1 & 29 \\
\hline Gamification (Gamificação) & 1 & 29 \\
\hline Outra & 1 & 28 \\
\hline Não faço uso de nenhuma destas abordagens metodológicas & 8 & 23 \\
\hline
\end{tabular}

Tabela 3: Adoção de abordagens educativas emergentes na formação inicial docente.

O respondente de ID 31 afirmou fazer uso da aprendizagem híbrida e da aprendizagem adaptativa e também de outras abordagens metodológicas mediadas por tecnologias. Ao especificar quais seriam, justificou:

\footnotetext{
"Não adoto a sala de aula invertida por discordar da minimização da docência desencadeada por essa abordagem. Não adoto gamificação por não gostar de games (nunca tive paciência para games), mas respeito a modalidade e a considero valiosa com recurso didático". (ID 31, Abordagens Educativas Emergentes)
}

Esta fala pontua um aspecto importante no que concerne a aceitação e adoção das tecnologias como parte da prática docente: o reconhecimento da validade e legitimidade de uma abordagem mediada por tecnologias. Quando o uso das tecnologias é consubstanciado por pressupostos onde se apresenta a técnica sobreposta à mediação nota-se maior desconfiança e resistência por parte dos professores.

$\mathrm{O}$ posicionamento dos professores respondentes quanto aos limites e possibilidades das TIC indica o reconhecimento de inúmeras possibilidades e algumas limitações, estas que acabam por condicionar o alcance das diferentes potencialidades das tecnologias aplicadas à educação e, por consequência, a adoção em maior ou menor grau de modelos híbridos e adaptativos. A maior limitação apontada é a baixa ou nula conectividade nos espaços da universidade, que se desdobra na dificuldade de acesso a diferentes recursos e conteúdos. Visto que esta se apresenta, na visão dos professores. como a maior potencialidade que a era digital oferece em termos de incremento do processo educativo, ampliando as possibilidades de comunicação, cooperação e colaboração, a conectividade precisa ser pensada como carro chefe de políticas de TIC a serem implementadas em escolas e universidades. A abordagem híbrida é reconhecida de forma mais clara no campo das possibilidades, na medida em que a flexibilização do tempo e do espaço, a adoção de diferentes tecnologias e metodologias de modo integrado e a ampliação 
do trabalho colaborativo são características diretamente vinculadas ao potencial que a tecnologia possui em termos de inovação pedagógica.

\begin{tabular}{|c|c|c|}
\hline Definição & Limites & Possibilidades \\
\hline $\begin{array}{l}\text { Aspectos relacionados ao } \\
\text { acessso à internet. }\end{array}$ & $\begin{array}{l}\text { "Na universidade não há sequer Wi-Fi para que se possa } \\
\text { experimentar algo além do power point"; Provimento de } \\
\text { acesso à internet; "O grande limite é não ter wifi em sala de } \\
\text { aula"; "Tampouco temos acesso a internet nas salas de } \\
\text { aulas"; "Dificuldade em acessar os aparelhos e a internet } \\
\text { durante as aulas"; "Dificuldades de infraestrutura"; } \\
\text { "Limitações infraestruturais das universidade" }\end{array}$ & $\begin{array}{l}\text { "Todos têm celular"; "Ressignificação da noção de espaço e tempo"; } \\
\text { "Velocidade de acesso à informação" }\end{array}$ \\
\hline $\begin{array}{l}\text { Aspectos relacionados à } \\
\text { infraestrutura necessária para o } \\
\text { acesso à recursos tecnológicos. }\end{array}$ & $\begin{array}{l}\text { "A maior dificuldade portanto é o acesso aos recursos"; } \\
\text { "Acessibilidade dos sujeitos e da incorporação das TDIC } \\
\text { crítica às práticas pedagógicas"; "O principal problema } \\
\text { quando há é o acesso"; "Disponibilidade para a utilização } \\
\text { dos equipamentos "; "Não temos acesso a laboratórios de } \\
\text { informática nem sequer a notebooks e data-shows ou } \\
\text { mesmo reprodutores de DVD"; Acesso, inclusive para os } \\
\text { professores formadores"; "Limite do recurso nâo estar } \\
\text { disponivel no ambiente escolar"; "Os limites estão na } \\
\text { disponibilidade das mesmas, já que não acessíveis a } \\
\text { todos(as) em termos de custos, além do fato de que } \\
\text { implicam custos de manutenção e atualização"; } \\
\text { "Dificuldade em acessar os aparelhos durante as aulas"; } \\
\text { "Equipamentos danificados e ou desatualizados"; "Não há } \\
\text { espaço e equipamentos na instituição"; "Falta de acesso a } \\
\text { todos, por causa do custo das tecnologias ou } \\
\text { infraestrutura da universidade"; "Limitaçães } \\
\text { infraestruturais das universidade"; "Dificuldade de acesso } \\
\text { a todos"; "O acesso e a disponibilidade" }\end{array}$ & $\begin{array}{l}\text { "Acessibilidade dos sujeitos e da incorporação das TDIC crítica às } \\
\text { práticas pedagógicas." "Procuro utilizar o que seja de maior } \\
\text { acessibilidade para os estudantes"; "Ressignificação da noção de } \\
\text { espaço e tempo"; "Velocidade de acesso à informação" }\end{array}$ \\
\hline $\begin{array}{l}\text { Relação entre o uso das TIC e a } \\
\text { motivação dos alunos. }\end{array}$ & $\begin{array}{l}\text { "Contexto dos alunos"; "Depende do contexto de cada } \\
\text { turma" }\end{array}$ & "Motivar os alunos"; "Depende do contexto de cada turma" \\
\hline $\begin{array}{l}\text { Aspectos relacionados às } \\
\text { competências e habilidades } \\
\text { docentes no uso das TIC. }\end{array}$ & $\begin{array}{l}\text { "Nos falta formação específica e recursos materiais para a } \\
\text { sua utilização"; "A maior limitação é a falta de formação } \\
\text { profissional para isso. Os próprios formadores de } \\
\text { professores carecem de formação específica"; "Os limites } \\
\text { são meus e não da TDIC"; "Os conhecimentos e vontade } \\
\text { dos professores em usá-las"; "Desconhecimento dos } \\
\text { professores"; "Dificuldades de infraestrutura"; "Limites } \\
\text { associados ao seu conhecimento e valorização do uso"; } \\
\text { "Formas de uso equivocadas"; "Operação técnica"; "Os } \\
\text { limites são dados pela formação dos professores, se não } \\
\text { sabem não usam". }\end{array}$ & $\begin{array}{l}\text { "Cada vez mais necessárias de serem incorporadas na formação } \\
\text { inicial de professores"; "Adoto outros recursos a título de ampliar a } \\
\text { inclusão digital dos estudantes"; "As TDIC estão cada vez mais } \\
\text { presentes no cotidiano e professores precisam estar familiarizados e } \\
\text { competentes em sua utilização"; "Inovação didática para a } \\
\text { aprendizagem das novas gerações" }\end{array}$ \\
\hline $\begin{array}{l}\text { Aspectos relacionados à } \\
\text { interação professor-alunos }\end{array}$ & $\begin{array}{l}\text { "Os limites são meus e não da TDIC"; "Os conhecimentos e } \\
\text { vontade dos professores em usá-las"; "Desconhecimento } \\
\text { dos professores"; "Limites associados ao seu } \\
\text { conhecimento e valorização do uso"; "Complexa gestão do } \\
\text { tempo"; "Formas de uso equivocadas"; "A falta de } \\
\text { interesse do professor/a" }\end{array}$ & $\begin{array}{l}\text { Possibilidade de contatar o aluno e/ou responde-lo fora do horário } \\
\text { da aula"; "Ressignificação da noção de espaço e tempo"; "Gerar } \\
\text { mais interação entre os sujeitos participantes do processo de ensino- } \\
\text { aprendizagem"; "O interesse do professor" }\end{array}$ \\
\hline $\begin{array}{l}\text { Aspectos relacionados à práticas } \\
\text { pedagógicas mediadas pelas } \\
\text { TIC. }\end{array}$ & $\begin{array}{l}\text { "Devem ser meios e não fins em si mesmas"; "Alguns } \\
\text { acham que se vão receber a apresentação da aula em PPT } \\
\text { não precisam fazer anotações e a responsabilidade se } \\
\text { dilui"; "Embora eu reconheça a importância das TDIC, } \\
\text { mantenho uma aula mais pautada na leitura atenta, } \\
\text { discussão conceitual e exercícios de campo sem a utilização } \\
\text { de TDIC"; "Os limites são meus e não da TDIC". }\end{array}$ & $\begin{array}{l}\text { "As possibilidades são interessantes e parecem muito abrangentes"; } \\
\text { "Realizar pesquisa nas ferramentas para descobrir algo que eu não } \\
\text { saiba dizer ou buscar informações complementares"; "Apoiar a } \\
\text { fixação do conteúdo"; "Adoto outros recursos a título de ampliar a } \\
\text { inclusão digital dos estudantes e para contemplar estratégias } \\
\text { didáticas"; "Ressignificação da noção de espaço e tempo"; } \\
\text { "Ampliação da ação coletiva nos processos de aprendizagem, a } \\
\text { viabilização de outras formas de debate e a facilidade de } \\
\text { comunicação entre os pares"; "Inovação didática para a } \\
\text { aprendizagem das novas gerações"; "Ampliar os recursos } \\
\text { disponíveis para os processos de aprendizagem" }\end{array}$ \\
\hline
\end{tabular}

Quadro 6: Limites e possibilidades das TIC na educação

Ao vislumbrar nas tecnologias um elemento que reconfigura a mediação pedagógica e as relações estabelecidas pela tríade professor-conhecimento-aluno, os professores se aproximam de um olhar holístico, onde as tecnologias estão incorporadas à uma prática educativa híbrida que emerge redimensionando as 
noções de espaço e tempo, demandando novas formas de apropriação das mesmas e uma postura, docente e discente, engajada digitalmente, na medida em que momentos de aprendizagem presencial e online devem ser pensados de forma concatenada.

Sobre a articulação currículo e tecnologias foi questionado como as políticas que preconizam a flexibilização curricular estão sendo abordadas na formação inicial docente. A Base Nacional Comum Curricular, teve suas diferentes versões assumidas como objeto de discussão e análise crítica, porém cabe refletir acerca da responsabilidade sobre o debate. Alguns professores, apesar de afirmarem que o tema vem sendo discutido em sua instituição de vínculo, informam que não o fazem pessoalmente pelo fato do tema não ser objeto de suas atividades de pesquisa e ensino, o que demonstra uma visão que não contempla a transversalidade do debate que a política, em vias de implementação, exige. Um dos respondentes questionou a validade de uma pergunta sobre flexibilização curricular no contexto de uma pesquisa sobre tecnologias na educação, o que gera uma reflexão a respeito do quanto as discussões em educação precisam deixar de lado uma perspectiva compartimentada em prol de uma perspectiva concatenada e convergente, visto, para fins de exemplificação da correlação existente entre os temas, que a Reforma do Ensino Médio ${ }^{16}$ prevê que até $40 \%$ das atividades pedagógicas podem ser realizadas a distância, por meio de tecnologias digitais. As falas reproduzidas abaixo sintetizam como o debate vem sendo conduzido, com enfoque nos interesses subjacentes à implementação das políticas e nas implicações pedagógicas e de controle e regulação da atividade docente.

\footnotetext{
"Temos realizado uma leitura crítica dessas políticas públicas e dos materiais publicizados, com vistas a esclarecer e reconhecer as consequências desses temas para a educação, de uma maneira geral, e para a prática docente, de uma maneira mais específica". (ID 23, $\mathrm{BNCC})$

\begin{abstract}
"Esses temas têm sido objeto de estudo, análise crítica e discussão de suas possibilidades e limites no que se refere ao desenvolvimento curricular. O controle e regulação da atividade docente possíveis de serem aprofundados por meio desses dispositivos curriculares são motivo de discussão e preocupação". (ID 27, BNCC)
\end{abstract}

\footnotetext{
${ }^{16}$ A Reforma do Ensino Médio (MP 746/2016) que altera a Lei de Diretrizes e Bases da Educação (Lei 0.394/96) e visa fomentar a oferta de educação em tempo integral para este nível de ensino. A organização curricular deverá estar estruturada em itinerários formativos com ênfase em uma das seguintes áreas de conhecimento: linguagens, matemática, ciências da natureza, ciências humanas e formação técnica e profissional. As únicas disciplinas com oferta obrigatória nos três anos do Ensino Médio são português, matemática e inglês; além disso, a medida ainda prevê que o cumprimento de exigências curriculares poderá ser realizado através da educação a distância ou adoção de modelos híbridos
} 


\begin{abstract}
"Por enquanto, há muito mais reação do que abordagem, uma vez que as fontes de informação e os enunciados já disponíveis acerca deste assuntos expõem muito da lógica de elaboração destas políticas. Ainda assim, me utilizo muito de instrumentos de pesquisas em sites, blogs, grupos e páginas em redes sociais para sistematizar as discussões em torno destes dois temas, por sinal, cercados de muitas controvérsias". (ID 16, BNCC)
\end{abstract}

\title{
3.6. Considerações Finais
}

Existe uma tensão entre o que a formação inicial deveria prover e as lacunas latentes que ela tem deixado, não somente no que se refere a incorporação das tecnologias na prática docente. A formação continuada de professores precisa reassumir seu papel originário de aperfeiçoamento profissional e não continuar se constituindo em uma estratégia permanente para corrigir falhas e preencher lacunas deixadas pela formação inicial, que por sua vez, precisa rever 'o peso na balança' entre suas componentes teórica e técnico-prática.

A criação de centros de investigação de prática educativa é uma sugestão de Gatti (2018) para diminuição do abismo existente entre a formação inicial e a prática docente nas escolas, assim como iniciativas que pensem a prática docente no Ensino Superior, especialmente nas licenciaturas - particularmente naquelas oferecidas na rede privada, que detêm a maioria das matrículas no país e, portanto forma a maior parte do contingente docente brasileiro -, que formam os futuros professores da Educação Básica. Esta proposta é corroborada por Martins (2015), que enfatiza a importância dos estudos científicos que visam melhor compreender os problemas educacionais, sendo portanto indispensáveis à decisão política. Entretanto, as observações in loco, de situações reais nos ambientes de formação, não costumam compor o processo de aferição da qualidade da formação docente, o que indica a necessidade de maior articulação entre teoria e prática não só na formação docente como também no âmbito da formulação de políticas educacionais, especialmente em termos de avaliação e acompanhamento.

Uma das estratégias adotadas no contexto brasileiro, a fim de que as mudanças previstas na Política Nacional de Formação de Professores se efetive é atuar no sentido do que já está estabelecido, o que acende um alerta quanto a adoção de uma lógica que não pressupõe uma reequilibração quanto a responsabilidade da formação docente. A então secretária executiva do MEC, Maria Helena Guimarães, em entrevista concedida a revista Nova Escola em novembro de 2017, sugeriu que, 
provavelmente a Base Nacional de Formação Docente, que contaria com uma matriz de referência com o perfil do futuro professor, não será obrigatória, mas que um dos mecanismos de indução para a efetiva implementação se daria junto às universidades privadas, que detêm o $62,9 \%$ das matrículas em cursos de licenciatura, através da criação de mais vagas no Programa Universidade Para Todos (Prouni).

No que concerne a discussão sobre o processo de incorporação das tecnologias digitais à educação e consequente adoção me modelos educativos híbridos e adaptativos, assim como na concepção da maior parte das políticas da área de educação e tecnologias e que já estava inscrita no projeto EDUCOM na década de 1980, os resultados desta pesquisa, mas detidamente as percepções e relatos dos professores que dela fizeram parte, está imbricada a ideia do computador e das tecnologias como um meio de ampliação das possibilidades educativas, sem que para isso se prescinda do papel do professor. No tocante aos fatores que se apresentam como entraves à incorporação das TIC à prática docente, a dificuldade de acesso à internet continua sendo um fator limitador, como apontado pelos respondentes da pesquisa, para o uso pedagógico das TIC, visto que cada vez mais a integração das tecnologias pressupõe a conectividade e a ubiquidade. Nesse sentido, a composição do Programa de Inovação Educação Conectada está consubstanciada em pressupostos que visam a correção deste problema, na medida em que (i) entende o emprego da tecnologia para a promoção da equidade em termos de acesso, com maior investimento e recursos de qualidade; (ii) objetiva a contemporaneidade em termos de aprendizagem, que deve buscar a customização da experiência educativa e (iii) e pretende fomentar a qualidade em termos de gestão, com base em pressupostos como eficácia e otimização de recursos.

Para a constituição de um saber docente específico, a formação inicial deve estar ancorada em uma tríade paradigmática, segundo a qual o professor deve ser preparado para assumir as seguintes funções: curador de informações, designer instrucional e orientador pedagógico. A curadoria exerce um papel central, na medida em que apresenta uma alternativa ao paradigma tradicional da docência como transmissão. O professor passa a fazer a triagem e seleção dos conteúdos e recursos disponíveis, que irão subsidiar a elaboração dos diferentes desenhos didáticos de suas aulas e cursos. A transposição didática perpassará todas as funções e será efetivada pela orientação, onde o professor assume um papel de mediador do 
processo de aprendizagem de seus alunos, em uma perspectiva cooperativa e colaborativa. 


\section{Síntese Conclusiva}

Esta síntese conclusiva tem por objetivo realizar uma discussão integrada dos resultados oferecendo respostas às questões norteadoras da pesquisa, para isso, foi organizada em três seções: na primeira foi adotado o formato de perguntas e respostas, buscando responder de maneira condensada às perguntas que mobilizaram esta investigação; na segunda, a apresentação e discussão da contribuição teórica da pesquisa: a constituição de uma tríade paradigmática para a formação docente na era digital; na terceira, são apresentados possíveis desdobramentos desta pesquisa. Cabe relembrar que a questão central que permeou os três estudos realizados, os limites e possibilidades das tecnologias digitais na educação, se mostrou uma questão latente, a ser considerada em pesquisas na área. De um modo geral, os resultados da investigação mostram a necessidade de maior interlocução entre os profissionais das áreas de Informática e Educação no desenvolvimento de ambientes e sistemas que suportem a aprendizagem híbrida e adaptativa, o que implica na realização de mais pesquisas de caráter experimental e, principalmente, na reconfiguração da formação docente, inicial e continuada, no sentido de preparar efetivamente os professores para exercerem seu papel, que já não é mais de transmissores do conhecimento, mas de mediadores no processo de aprendizagem, ressignificando seu modus operandi com base nos princípios da curadoria, design e orientação.

\subsection{Respondendo às Questões da Pesquisa}

Como são concebidos e como funcionam os sistemas informáticos que consubstanciam a adoção de modelos educacionais híbridos e adaptativos?

A capacidade de aprendizagem de máquinas, através da introdução de dados por seus usuários é enorme, na medida em que por meio da mineração de dados é possível detectar padrões em grandes volumes de dados, podendo trazer benefícios à educação de uma maneira geral, na medida em que a análise desses dados pode oferecer subsídios para se pensar os diferentes fatores intervenientes no processo de aprendizagem. Porém, na medida em que o sistema é quem direciona o percurso a ser trilhado pelo aluno, através das entradas que recebe, tem-se um sistema adaptado e personalizado, mas não se tem, ainda, a adaptação da aprendizagem. É importante sempre ter em conta que o que precisa estar adjetivado é a 
aprendizagem, é ela que deve passar pelo processo de adaptação às necessidades individuais de cada aprendente. Os sistemas informáticos devem se estruturar de forma a prover a adaptação, que deve garantir a adaptabilidade e por consequência a customização da aprendizagem, o que em termos pedagógicos é o desejável, pois se alinha ao pressuposto da autonomização do processo de aprendizagem e da responsabilização do aluno sobre o mesmo.

O principal problema detectado através da revisão sistemática da literatura sobre aprendizagem híbrida e adaptativa se refere à aplicação indiscriminada das teorias de estilos de aprendizagem, especialmente a preconizada por Felder e Silverman (1998), inspirada em Kolb (1984), pois este modelo divide os aprendentes, basicamente, entre aqueles que preferem aprender pela experiência e os que preferem aprender pela teoria, quando uma educação bem planejada e executada deve justamente buscar o entrelaçamento entre teoria e prática.

Por fim, o processo de adaptação por meios informáticos precisa passar por um desencantamento se realmente se propuser a viabilizar uma aprendizagem que respeite o ritmo e a forma de aprender individuais. A escolha do termo desencantamento não é aleatória e remonta Max Weber (2004) e sua proposição de desencantamento do mundo, que se refere à desmagificação da realidade através do desencantamento religioso. Como Gourlay (2017) aponta, o digital, no âmbito das políticas educacionais, ainda está sob uma aura de magia, cujo potencial é sobrevalorizado e onde o aprendente aparece na perspectiva de usuário. A tecnologia vem se constituindo como via de democratização da educação, porém, enquanto este processo se pautar pela lógica do consumo não poderemos alcançar a emancipação humana e cidadã.

Como se constituem teoricamente e como se operacionalizam na prática as aprendizagens híbrida e adaptativa, entendidas como abordagens educativas emergentes mediadas pelas tecnologias digitais?

Apesar da grande movimentação e expectativa em torno das chamadas metodologias ativas, que ensejam as abordagens educativas emergentes que foram objeto de estudo desta pesquisa, elas não são novidade. Illich (1985) preconizava um modelo educacional baseado em redes de aprendizagem que ofereceriam suporte para (i) acessar objetos educacionais de aprendizagem, apoiando a educação formal; (ii) promover a cooperação através do intercâmbio de competências, onde 
as relações de aprendizagem se estabeleceriam sob o signo da complementariedade; (iii) promover a colaboração, numa lógica de aprendizagem por pares e (iv) estimular a aprendizagem pessoal e personalizada, onde a aprendizagem estaria menos vinculada à instituições educativas e se tornaria mais acessível através de educadores profissionais.

No que concerne a mediação, Vygotsky (2010) deixa claro que o papel do professor e das instituições de ensino é prover o desenvolvimento global dos alunos, o que implica empreender esforços no sentido de desenvolver o que falta aos alunos. Se cabe ao professor, em uma perspectiva vygotskyana, oferecer aos alunos novas oportunidades de aprendizagem a partir da identificação daquelas que se encontram em estágio embrionário, a tecnologia pode auxiliar o professor nesse processo de identificação, visto que pode contribuir para a avaliação diagnóstica do nível de desenvolvimento real dos alunos, indicando o ponto de partida dos percursos de aprendizagem que levem os alunos a atingirem sua zona de desenvolvimento proximal. Como consequência, o professor poderá se dedicar às atividades que devem compor o novo perfil docente: (i) a de designer, de ambiente e conteúdos, numa perspectiva de autoria; (ii) a de curador, que seleciona e organiza a informação, numa perspectiva de cooperação e (iii) a de orientador, que mobiliza os conhecimentos, numa perspectiva de colaboração.

\section{A formação inicial de professores contempla em seu currículo e adota em suas práticas estas abordagens educativas emergentes mediadas pelas tecnologias digitais? De que forma?}

A presença da educação a distância via internet no Ensino Superior começa a ser forjada na década de 90, passando a ser oficializada como modalidade de ensino a partir da criação da Secretaria de Educação a Distância, em de 1996, e, atualmente continua seu processo de expansão, se consolidando como a modalidade que mais forma professores no país. No Ensino Superior, $75 \%$ das matrículas é na rede privada, 59\% dos cursos de licenciatura da rede privada é oferecido na modalidade a distância. A tendência é de crescimento, tendo em vista a aprovação recente da nova legislação que passa a regulamentar a educação a distância no país cujas mudanças principais estão na possibilidade de ampliação da oferta de cursos superiores de graduação e pós-graduação a distância, a criação de polos de $\mathrm{EaD}$ 
pelas próprias instituições e o credenciamento de instituições na modalidade $\mathrm{EaD}$ sem exigir o credenciamento prévio para a oferta presencial.

Enquanto isso, ainda se discute se deve-se usar ou não a tecnologia para fins educacionais; a pesquisa e o debate - especialmente através da inclusão de disciplinas curriculares específicas nos cursos de licenciatura, como os dados da pesquisa mostraram -, sobre como se usar, e se apropriar a eficácia do uso e a formação docente alinhada ao paradigma digital, dada a realidade supracitada, ainda são insuficientes. Os professores formadores, por sua vez, também carecem de formação adequada para preparar os futuros professores da educação básica, especialmente para o seu papel de designer. O descompasso entre a realidade digital na qual estamos inscritos e a realidade das escolas e da formação inicial de professores, ainda estruturadas pela dicotomia digital-analógico, se apresenta como um dos achados, que não é inédito, desta pesquisa. A relação entre os investimentos governamentais em infraestrutura e formação de professores para o uso efetivo e escalonado das TIC pelos professores em atividades pedagógicas é algo a ser pesquisado e debatido em maior volume e com maior atenção.

\subsection{A Tríade Paradigmática da Formação Docente na Era Digital: Curadoria, Design e Orientação}

O esquema a seguir demonstra os caminhos possíveis na relação educação e tecnologias, expressão que intitula esta tese. É resultado das contribuições dos três estudos que a compõe, na medida em que cada um apresentou um dos conceitos que constitui a tríade paradigmática da formação docente na era digital. Ao abordar esta relação de forma instrumental construímos e atualizamos teorias, ao passo que a abordagem aplicada nos conduz a produção de diferentes desenhos didáticos. A curadoria se encontra no centro deste processo, visto que subsidia tanto a dimensão instrumental, que se refere ao uso da tecnologia na educação, quanto a dimensão de aplicação, que se refere à criação dos mais diferentes recursos educacionais a partir da integração/incorporação das tecnologias. O aporte teórico e o desenho didático serão elementos dialógicos na construção do processo de mediação pedagógica, onde o professor se coloca essencialmente como curador e orientador no processo de aprendizagem. 


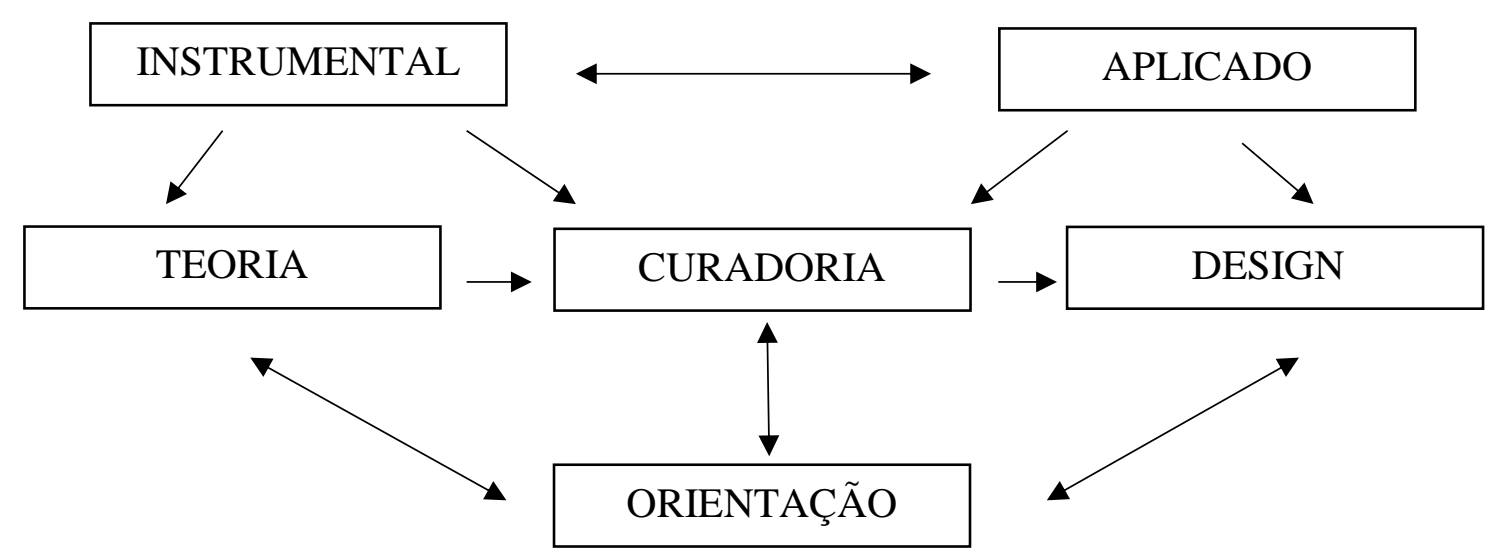

Ao avaliar as propostas e experiências de aprendizagem híbrida e adaptativa no primeiro estudo, para além da observância da necessidade de maior integração entre profissionais de informática e educação, destacou-se a necessidade dos professores compreenderem o funcionamento de ambientes, plataformas e sistemas que apoiam a adoção de ambientes híbridos e consubstanciam a aprendizagem adaptativa, na medida em que os mesmos serão mais efetivos se contarem com o auxílio de especialistas em educação no seu desenvolvimento. Isso demanda do professor que assuma seu papel de designer, colaborando no design de ambientes, plataformas e sistemas, indicando seus requisitos pedagógicos e identificando abordagens educativas e metodologias didáticas que mais se adequam a adoção dos mesmos.

Ao me colocar no papel de designer de um curso online para explorar e operacionalizar os conceitos de aprendizagem híbrida e adaptativa, encontrei na orientação, ancorada pela noção de virtualização da presença e na mediação vygotskyana, um elemento chave para composição de um ethos docente que atenda às demandas da educação na era digital,

Ao buscar respostas na composição política da formação de professores e integração das tecnologias à educação e seus desdobramentos nos currículos e práticas da formação inicial de professores, me deparei com o ascensão da curadoria como componente central tanto na esfera teórica, na forma de competência ser estimulada e desenvolvida entre os alunos, quanto na esfera prática, o identificar na composição dos currículos e nas respostas dos professores formadores, uma crescente preocupação em ultrapassar a dimensão instrumental do uso da tecnologia. 


\subsection{A Pesquisa em Perspectiva: Novas Questões e Trabalhos}

\section{Futuros}

Os resultados dos três estudos da tese suscitaram algumas questões que podem vir a ser respondidas por investigações futuras, preferencialmente com a utilização de pesquisa experimental:

1. Como a avaliação educacional pode ser aprimorada com o uso de sistemas adaptativos? Quais os impactos na aprendizagem?

2. Que modelos de mediação melhor se adequam a abordagens educativas híbridas? Quais os impactos na avaliação de desempenho dos aprendizes?

3. Como as universidades privadas, que formam o maior contingente docente no Brasil, estruturam suas licenciaturas? Há integração das TIC em suas propostas curriculares e prática docente? 


\section{Referências Bibliográficas}

ADAMS BECKER, S.; CUMMINS; M., DAVIS, A.; FREEMAN, A.; HALL GIESINGER, C.; ANANTHANARAYANAN, V. NMC Horizon Report: 2017 Higher Education Edition. Austin, Texas: The New Media Consortium, 2017.

AGUIAR, J.J.B.; FECHINE, J.M.; COSTA, E.B. Estilos Cognitivos e Estilos de Aprendizagem em Informática na Educação: Um Mapeamento Sistemático Focado no SBIE, WIE e RBIE. SBIE, 2014b.

AGUIAR, J.J.B.; SANTOS, S.I.N.; FECHINE, J.M.; COSTA, E.B. Avaliação de Sistemas de Recomendação Educacionais no Brasil: Uma Revisão Sistemática da Literatura, SBIE, 2015.

AGUIAR, J.J.B.; SANTOS, S.I.N.; FECHINE, J.M.; COSTA, E.B. Um Mapeamento Sistemático sobre Iniciativas Brasileiras em Sistemas de Recomendação Educacionais, SBIE, 2014a.

ANDERSON, T. Personalized learning systems and you. PLE Conference, Universidade de Manitoba, 2007.

ANDRADE, J.Z. A inserção e o uso das TIC nas escolas públicas do estado do Rio de Janeiro - estudo de caso com os concluintes do curso de pós-graduação lato sensu "Tecnologias em Educação - CCEAD/PUC Rio". Rio de Janeiro, 114p. Dissertação de Mestrado - Departamento de Educação, Pontifícia Universidade Católica do Rio de Janeiro.

BACICH, L.; TANZI NETO, A.; TREVISANI, F. M. (Org.). Ensino híbrido: personalização e tecnologia na educação. Porto Alegre: Penso, 2015.

BARBER, M., DONNELLY, K.; RIZVI, S. An avalanche is coming. London, UK: Institute for Public Policy Research, 2013. Disponível em: http://www.avalancheiscoming.com/.

BARDIN, L. Análise de conteúdo. Lisboa: Edições 70. 1977.

BECKER, H.S. Segredos e truques da pesquisa. Rio de Janeiro: Zahar, 2007.

BERNARDO, S.F. Contribuições do Google sala de aula para o ensino de idiomas: relato de experiência. Anais do $15^{\circ}$ Congresso Internacional de Tecnologia na Educação. Recife: 2017.

BRÁS, P.; MIRANDA; G. L.; MARÔCO, J. Teachers and technology: A complicated relationship. GSTF International Journal on Education (JEd), 2(1), 56-65, 2014.

BRASIL. Decreto ${ }^{\circ} 8.752$ de 9 de maio de 2016. Dispõe sobre a Política Nacional de Formação dos Profissionais da Educação Básica. Casa Civil. Diário Oficial da República Federativa do Brasil, Brasília, DF, 09 mai. 2016. 
BRASIL. Decreto $\mathbf{N}^{\circ} 9.204$ de 23 de novembro de 2017. Institui o Programa de Inovação Educação Conectada e dá outras providências.. Casa Civil. Diário Oficial da República Federativa do Brasil, Brasília, DF, 23 nov. 2017.

BRASIL. Lei $\mathbf{n}^{\circ}$ 13.005, de 25 de junho de 2014. Aprova o Plano Nacional de Educação - PNE e dá outras providências. Diário Oficial da República Federativa do Brasil, Brasília, DF, 25 jun. 2014.

BRASIL. Lei $\mathbf{n}^{\circ}$. 9.394, de 20 de dezembro de 1996. Estabelece as diretrizes e bases da educação nacional. Diário Oficial da União, Brasília, 23 dez. 1996.

BRASIL. Lei $\mathbf{n}^{\mathbf{0}}$ 13.415, de 16 de fevereiro de 2017. Conversão da Medida Provisória ${ }^{\circ} 746$, de 2016. Casa Civil. Diário Oficial da República Federativa do Brasil, Brasília, DF, 16 fev. 2017.

BRUSILOVSKY, P. Adaptive hypermedia. User Modeling and User-Adapted Interaction, 11 (1-2):87-110, 2001.

CAMPBELL COLLABORATION. What is a systematic review? Disponível em https://campbellcollaboration.org/research-resources/writing-a-campbellsystematic-review/systemic-review.html. 2017.

CAZELLA, S. C.; NUNES, M. A. S. N.; REATEGUI, E. B. A Ciência da Opinião: Estado da arte em Sistemas de Recomendação. In XXX Congresso da Sociedade II Congresso Brasileiro de Informática na Educação (CBIE 2013). II Jornada de Atualização em Informática na Educação (JAIE 2013) Jornada de Atualização em Informática (JAI), 2010.

CETIC. (2010 a 2016). TIC e Educação. Disponível em: http://data.cetic.br/cetic/. 2017.

CHRISTENSEN, Clayton; HORN, Michael; STAKER, Heather. Ensino híbrido: uma inovação disruptiva? uma introdução à teoria dos híbridos. Maio 2013. 49 p. Disponível em: https://www.christenseninstitute.org/publications/ensinohibrido.

CLARK, A. Natural-born cyborgs. Oxford, NY: Oxford University Press, 2003.

COStA, E; AGuiAR, J.; MAGAlHÃES, J. Sistemas de Recomendação de Recursos Educacionais: Conceitos, Técnicas e Aplicações. CBIE, 2013.

DRISCOLL, Margaret. Blended learning: Let's get beyond the hype. e-learning. IBM Global Services. Mar. 2002, 1.4: 1-4. Disponível em: https://www07.ibm.com/services/pdf/blended_learning.pdf.

DRUMOND, L.R.; LINDOSO, A.N.; GIRARDI, R. Infonorma: Um Sistema de Recomendação Baseado em Tecnologias da Web Semântica. Infocomp Journal of Computer Science, v.5, n.4, 2006.

FAURE, P. Ensino personalizado e comunitário. São Paulo: Edições Loyola, 1993. 
FELDER, R. M.; SILVERMAN, L. K. Learning and teaching styles in engineering education. Engineering education, 78(7):674-681, 1988.

FERREIRA, L.; GAZZOLA, M.; FERRARI, D.; ZUPELARI, M.; PAIVA, P.; RODRIGUES, J. Métodos de classificação aplicados à detecção automática de Estilos de Aprendizagem em um ambiente real de ensino. SBIE, 2017.

FONSECA, J. J. S. Metodologia da Pesquisa Científica. Fortaleza: UEC, 2002.

GATTI, B. Por uma Política de Educação de Professores. São Paulo: Pesquisa FAPESP, edição 267, mai.2018.

GATTI, B. Estudos quantitativos em educação. Educação e Pesquisa, São Paulo, v.30, n.1, p. 11-30, jan./abr. 2004.

GAVIDIA, J. J. Z.; ANDRADE, L. C. V. Sistemas tutores inteligentes. Trabalho de Conclusão da Disciplina de IA, Universidade Federal do Rio de Janeiro. Rio de Janeiro - RJ: UFRJ, 2003

GOURLAY, L. Re-corporificando a universidade digital. In Educação e tecnologia: abordagens críticas. Rio de Janeiro: UNESA, 2017.

GUMBRECHT, H.U. Produção de presença - O que o sentido não consegue transmitir. Rio de Janeiro: Contraponto/PUC Rio, 2010.

GÜNTHER, H. Pesquisa qualitativa versus pesquisa quantitativa: esta é a questão? Brasília, Psicologia: Teoria e Pesquisa, vol. 2, n.2, maio/ago 2006.

HENRIQUE, M.S.; SILVA, C.T.L.L.; SILVA, D.R.D.; TEDE, P.C.A.R. Uma Revisão Sistemática da Literatura sobre o Uso de Teorias de Aprendizagem em Softwares Educacionais. RENOTE, v.13, n.2, 2015.

HILL, M.; HILL, A. Investigação por Questionário. Lisboa: Edições Sílabo, 2016.

HORN, M. B.; STAKER, H. Blended: usando a inovação disruptiva para aprimorar a educação. Tradução: Maria Cristina Gularte Monteiro. Porto Alegre: Penso, 2015.

ILLICH, I. Sociedade sem escolas. Petrópolis: Vozes, 1985.

INEP/MEC. Melhores práticas em escolas de Ensino Médio no Brasil. Brasília, 2010.

JOHNSON, L.; ADAMS BECKER, S.; ESTRADA, V.; FREEMAN, A. NMC Horizon Report: Edição Educação Básica, 2015. Austin, Texas: The New Media Consortium, 2015.

KIRSCHNER, P. A. (2017). Stop propagating the learning styles myth. Computers and Education, 106:166-171. 
KOLB, D. A. Experiential learning: Experience as the source of learning and development. New Jersey: Prentice-Hall, 1984.

LICHTNOW, D.; LIMA, J. V.; LOH, S.; GARIN, R. S.; PALAZZO, L. A. M.; PRIMO, T.; KAMPFF, A. J. C.; Oliveira, J. P. M. O uso de técnicas de recomendação em um sistema para apoio a aprendizagem colaborativa. Revista Brasileira de informática na educação (RBIE), 14(3):49-59, 2006.

MACHADO, G.M.; MARAN, V.; OLIVEIRA, J.P.M.; GASPARINI, I.; PERNAS, A. Uma Revisão Sistemática sobre as Abordagens Ubíquas para Recomendação Educacional: Estariam Elas se Tornando Adaptativas?, SBIE, 2015.

MARTINS, I (2015). Formação Inicial de Professores: Um Debate Inacabado. Lisboa: Conselho Nacional de Educação, nov.2015.

MEC. Base Nacional Comum Curricular - BNCC 3 $3^{\text {a }}$ versão. Brasília, DF, 2017.

MEC. Censo da Educação Superior 2016. Brasília : Instituto Nacional de Estudos e Pesquisas Educacionais Anísio Teixeira, 2017.

MEC. Resolução no 2, de $\mathbf{1}^{\mathbf{0}}$ de julho de 2015. Define as Diretrizes Curriculares Nacionais para a formação inicial em nível superior e para a formação continuada. Brasília, DF, 2015.

MONTEIRO, A.; MOREIRA, J. A.; LENCASTRE, J. A. Blended (e) learning na sociedade digital. Santo Tirso: White Books, 2015.

MORGADO, L. Piaget, Um Pedagogo? In Miranda, G., Bahia, S. (org) Psicologia da Educação: Temas de Desenvolvimento, Aprendizagem e Ensino. Lisboa: Relógio d'Água, 2005.

NASCIMENTO, J.K.F. Informática Aplicada à Educação. Brasília : Universidade de Brasília, 2009.

NEVADO, R. A.; CARVALHO, M.J.S.; MENEZES, C.S. Arquiteturas Pedagógicas para Educação a Distância. In Aprendizagem em Rede da Educação a Distância: Estudos e Recursos para a Formação de Professores. Porto Alegre: Ricardo Lenz, 2007.

NEWTON, P. M.; MIAH, M. Evidence-Based Higher Education - Is the Learning Styles “Myth” Important? Frontiers in Psychology, v. 8, 444, 2017.

NÓVOA, A. Os Professores e as Histórias da sua Vida. In Vida de Professores. Porto: Porto Editora, 2000.

PASHLER, H.; MCDANIEL, M.; ROHRER, D.; BJORK, R. Learning Styles: Concepts and Evidence. Psychological Science in the Public Interest, v. 9, n. 3, p. 105-119, 2009.

PIAGET, J. A Equilibração das Estruturas Cognitivas. Rio de Janeiro: Zahar, 1975. 
ROSADO, L. A. S.; CARVALHO, J. S. (Org.). Educação e tecnologia: abordagens críticas. Rio de Janeiro: Editora UNESA, 2017.

SCHNEIDERS, L.A.; CYRNE, C.C.S. Tecnologia educacional e rentabilidade: $O$ impacto financeiro do programa Google Apps for Education na Univates. XVII Colóquio Internacional de Gestão Universitária. Argentina: 2017.

SIEMENS, G. Adaptive learners, not adaptive learning. Elearnspace. Disponível em http://www.elearnspace.org/blog/2016/07/20/adaptive-learners-not-adaptivelearning/, 2016.

SILVA, F.C.S.; E BARCELOS, G.T. Sala de Aula Invertida: uso do Google Classroom no estudo de História. Anais do $9^{\circ}$ Congresso Integrado da Tecnologia da Informação, 2017.

SILVA, M. (org). Educação online: teorias, práticas, legislação, formação corporativa. São Paulo, Loyola, 2003.

SLEEMAN, D.H. Intelligent tutoring systems: a review. Report No. IR011683. Stanford, CA, 1984.

TANG, T; MCCALLA, G. Beyond learners' interest: Personalized paper recommendation based on their pedagogical features for an e-learning system. PRICAI, 2004.

TEO, T. Modelling technology acceptance in education: A study of pre-service teachers. Computers \& Education, 52, pp. 302-312, 2009.

TOLEDO, J.V.; ROCHA, F.G.; NUNES, A.K., Google Classroom: qualificação docente para o uso de novas tecnologias. Cadernos da Fucamp, v.17, n.29, p.1424,2018 .

VIEIRA JUNIOR, R.R.M.; SANTOS, O.L.; RAFALSKI, J.P.; BADA, E.M.; SILVA, H.F.A.; MENEZES, C.S. Coordenação nas Atividades Colaborativas em Ambientes de Aprendizagem: Uma Avaliação na Implementação de Arquiteturas Pedagógicas. RENOTE, v.9, 2011.

VOSGERAU, Dilmeire Sant'Anna Ramos; ROMANOWSKI, Joana Paulin. Estudos de revisão: implicações conceituais e metodológicas. Revista Diálogo Educacional, Curitiba, v. 14, n. 41, p. 165-189, jan./abr. 2014.

VYGOTSKY, L. A formação social da mente - o desenvolvimento dos processos psicológicos superiores. São Paulo: Martins Fontes, 2010.

VYGOTSKY, L. Pensamento e Linguagem. São Paulo: Martins Fontes, 2005.

WEBER, M. A ética protestante e o espírito do capitalismo. São Paulo: Martin Claret, 2002.

WEBER, M. Economia e Sociedade - Volume 1. Editora UNB, 2000. 
WEIBELZAHL, Stephan. Evaluation of adaptive systems. In: International Conference on User Modeling. Springer Berlin Heidelberg,. p. 292-294, 2001.

WENGER, E. Artificial Intelligence and Tutoring Systems: Computational and Cognitive Approaches to the Communications of Knowledge. Los Altos, CA: Morgam Kaufmann Publishers. 1987.

WILSON, M. Six views of embodied cognition. Psychonomic Bulletin \& Review, 9 (4), 2002 


\section{ANEXO}

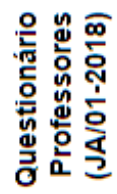

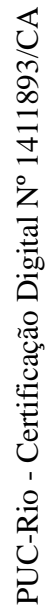

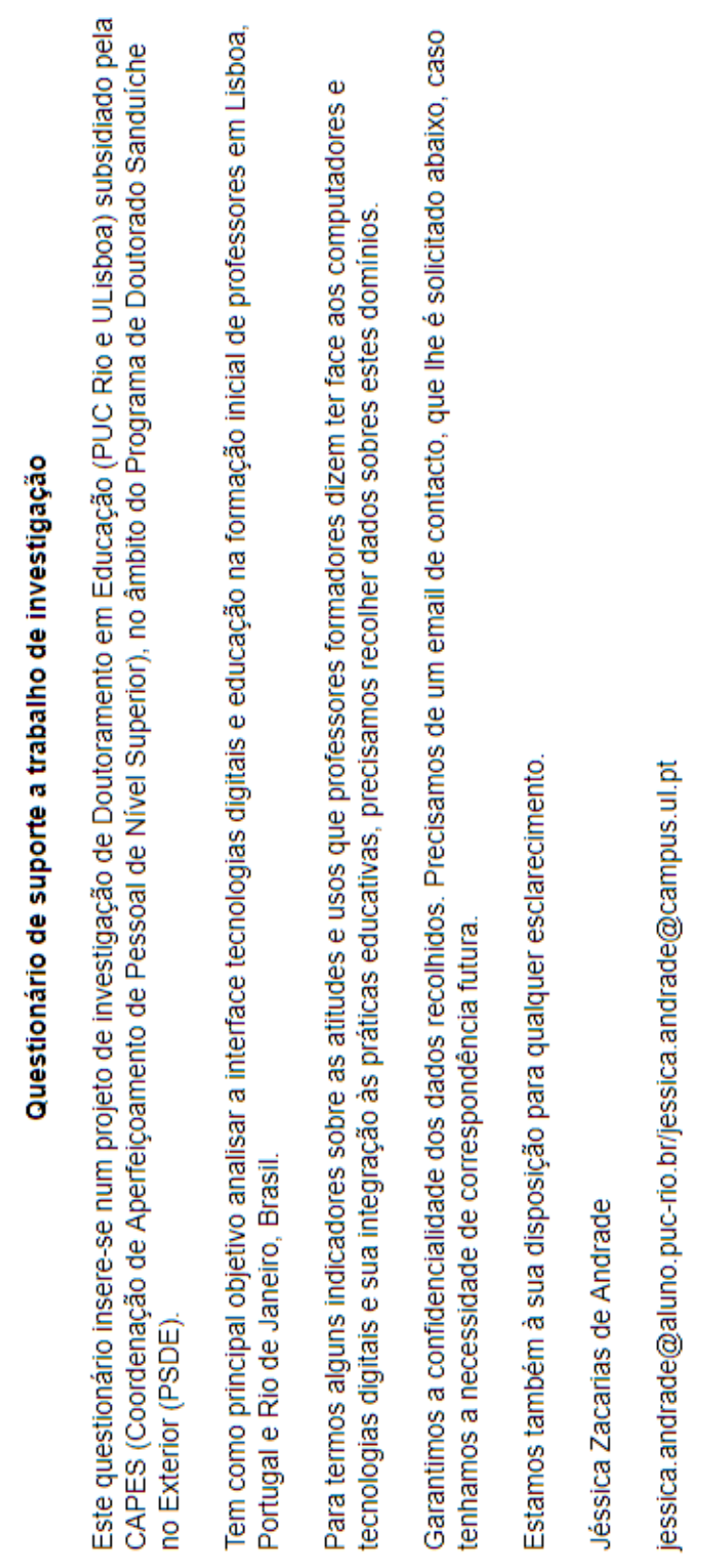




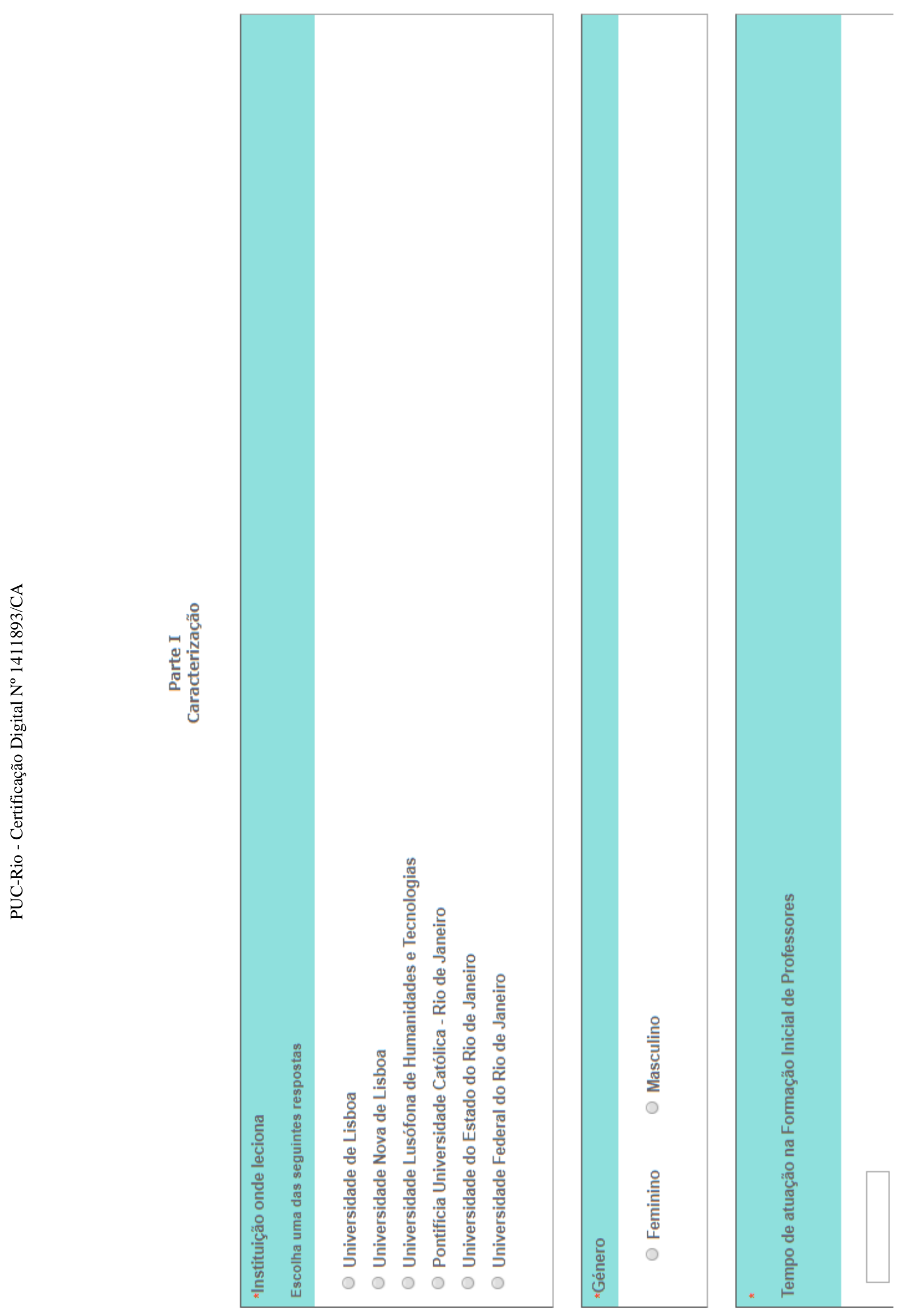



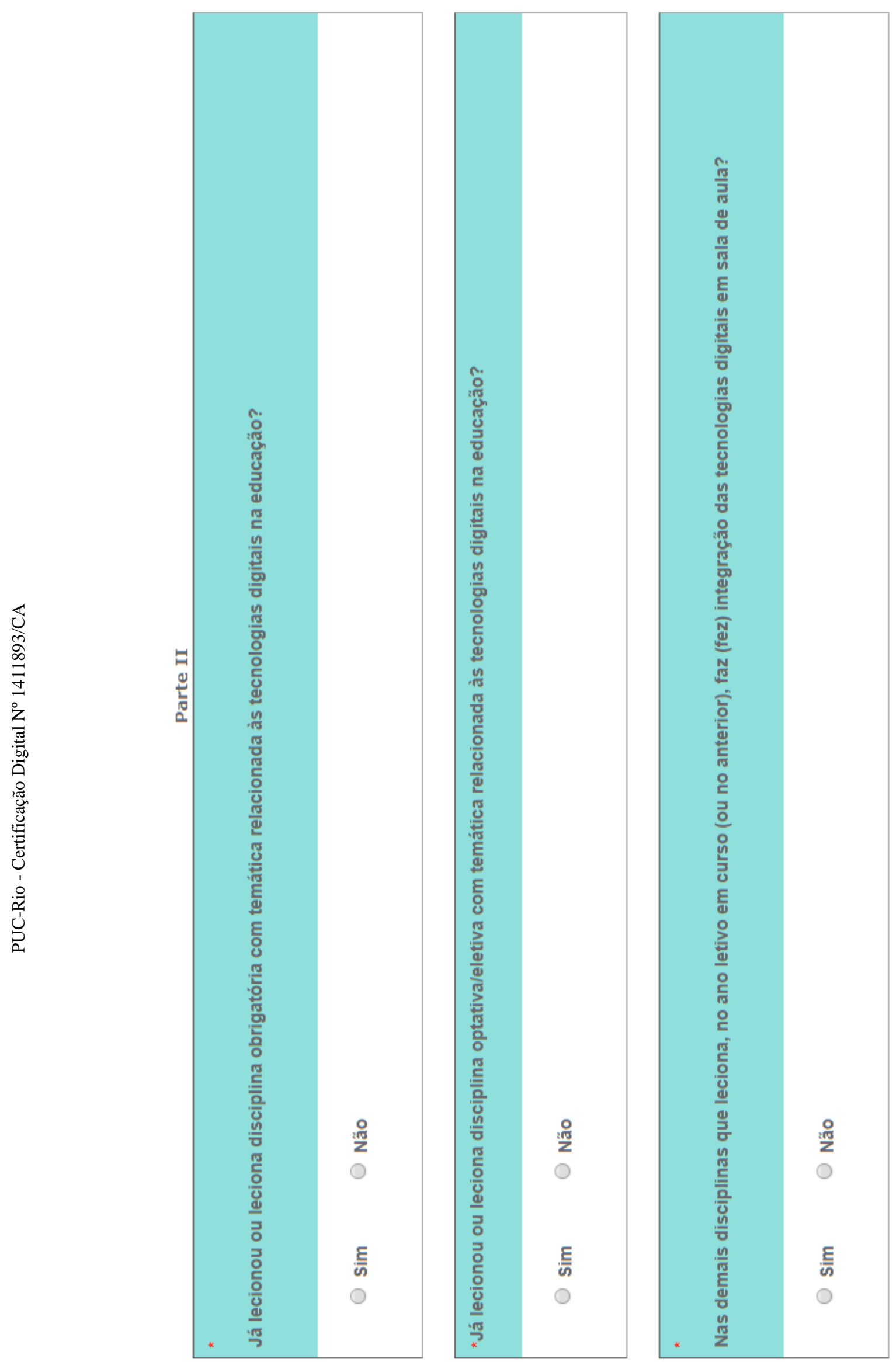


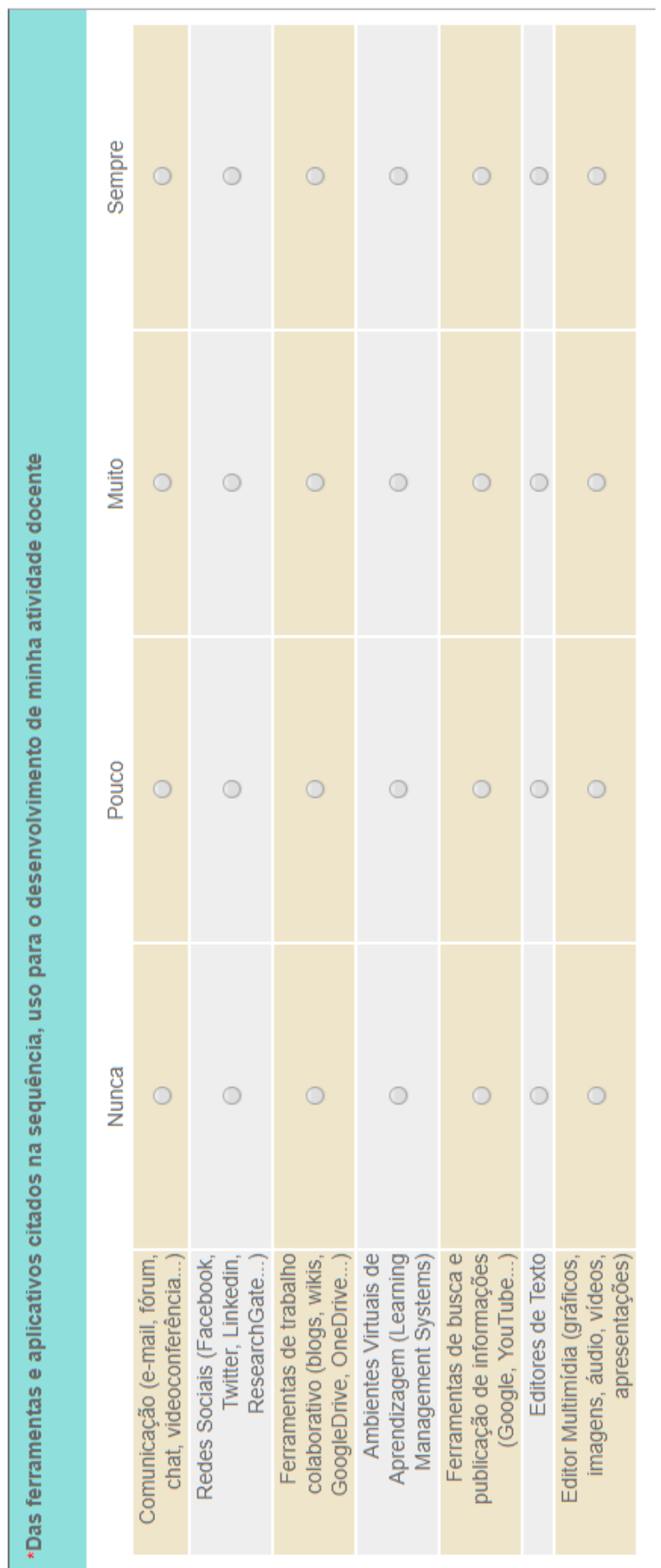




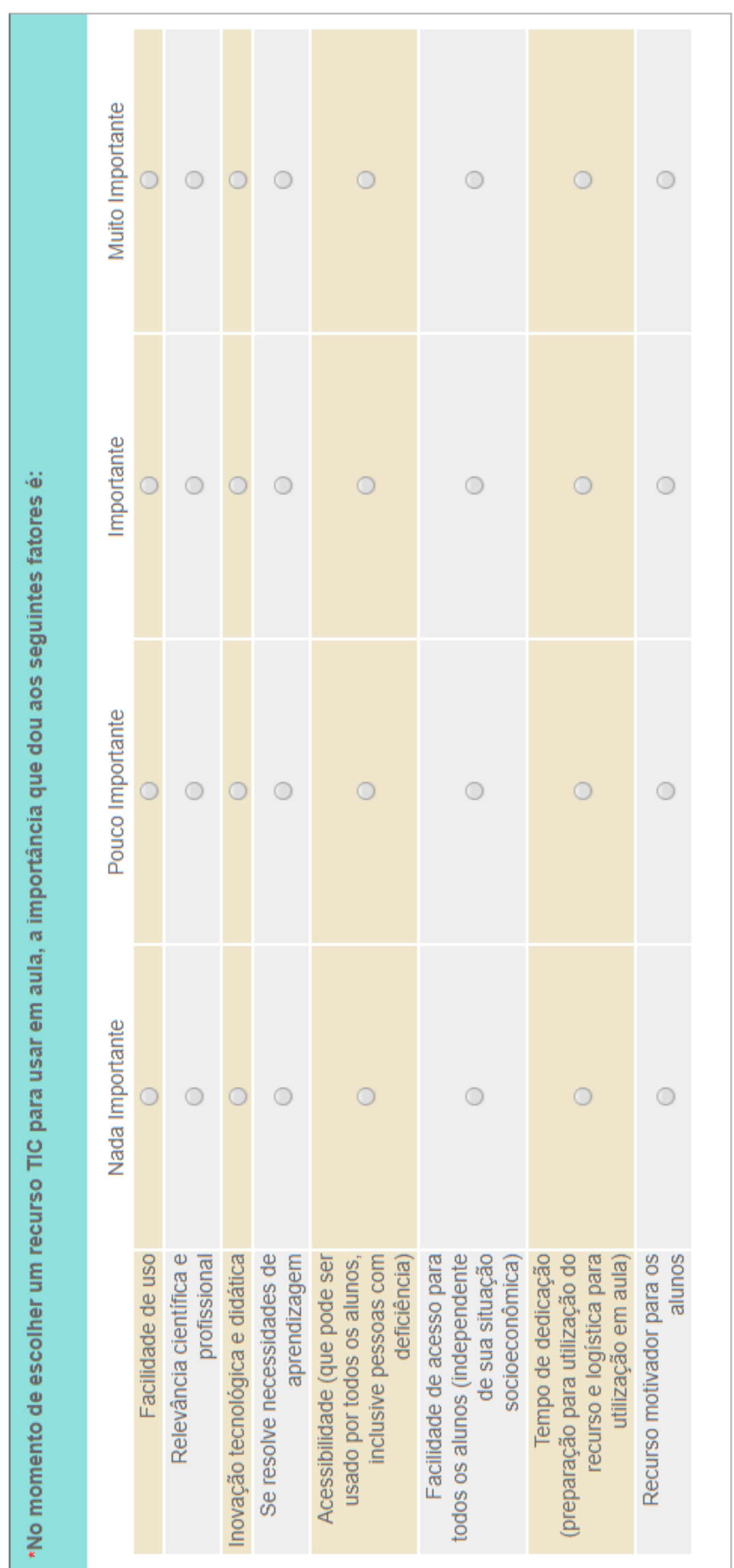




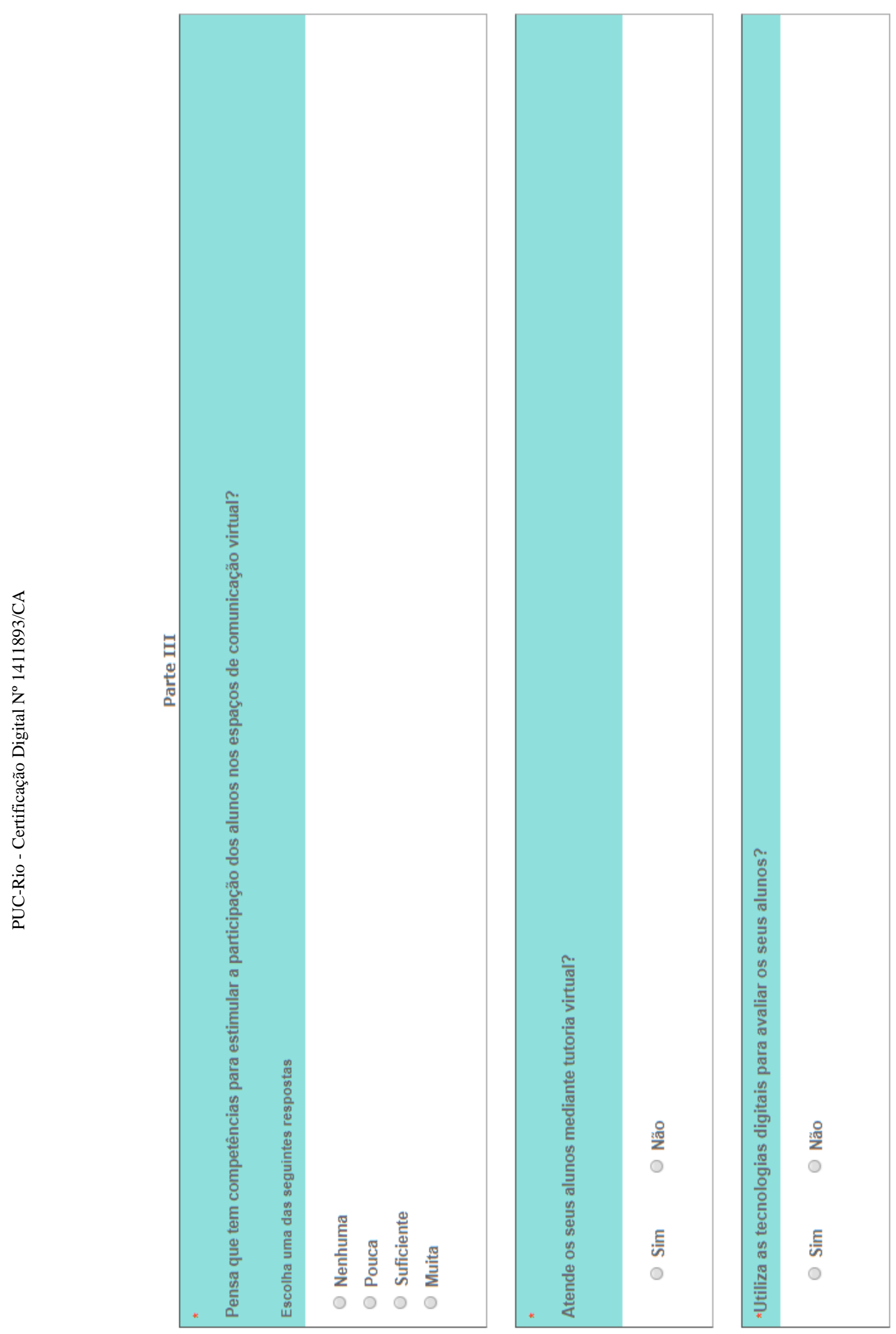



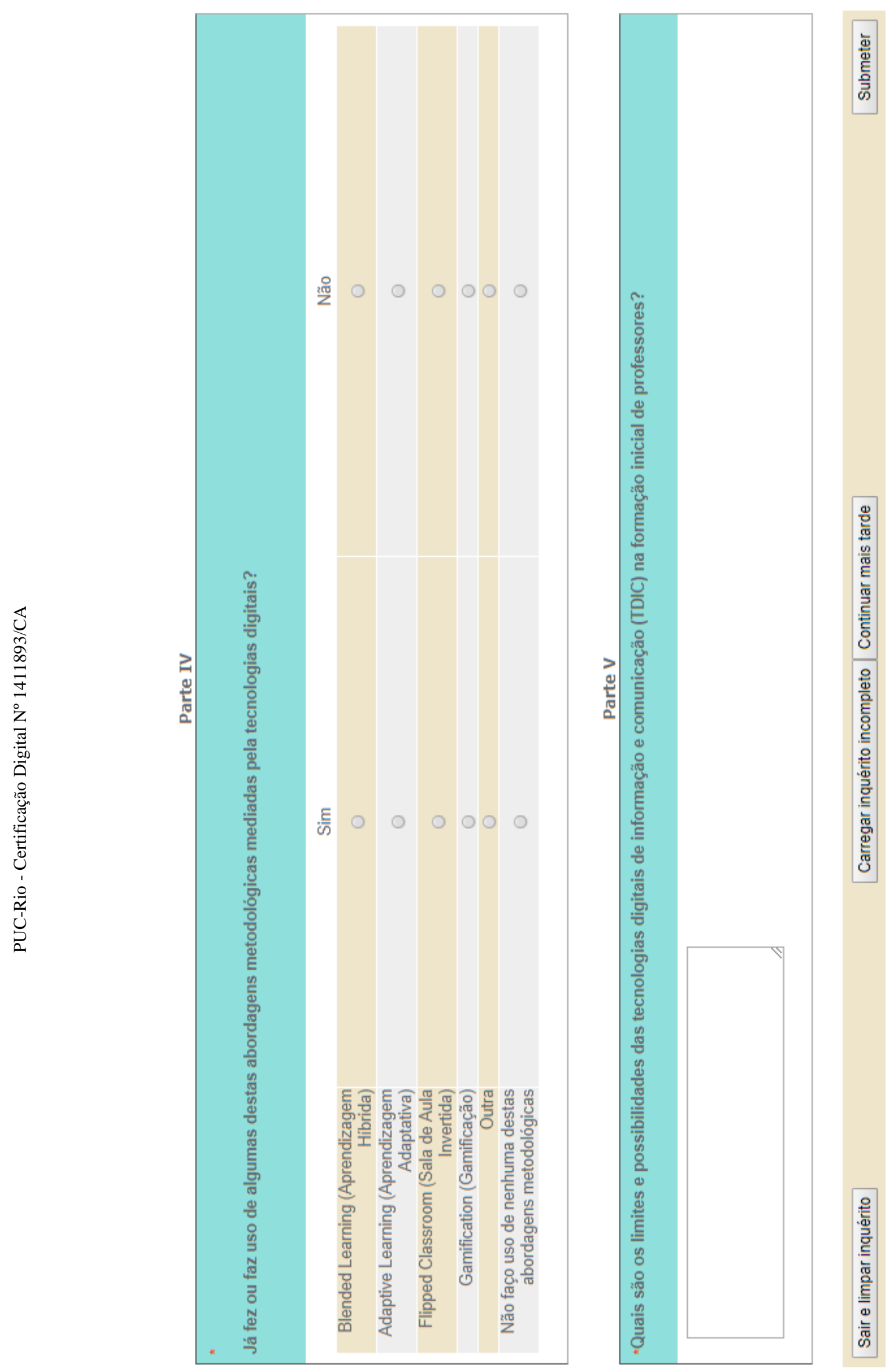